\title{
Het vergiftigde geschenk: elkeen wordt geacht de wet te kennen
}

\author{
Ignace Claeys en Ludo Cornelis ${ }^{*}$
}

\section{Inleiding}

I. Nemo censetur ignorare legem; elkeen wordt geacht de wet te kennen. Het zou van een overdosis optimisme getuigen te denken dat dit onderwerp op juridisch enthousiasme kan rekenen. Vele juristen halen de neus op voor een thema van dit soort of kunnen nauwelijks een zucht van (aankomende) verveling onderdrukken. Het onderwerp geeft uitzicht op - langdradige - theoretische beschouwingen, waarin publiek- en privaatrecht moeilijk van elkaar zijn te onderscheiden. De eerlijkheid gebiedt overigens te erkennen dat het (zelfs universitaire) onderricht minder en minder aandacht aan de theoretische onderbouw van het rechtsgebeuren besteedt, zodat de bouwstenen om het recht theoretisch te bedrijven en te analyseren, veelal ontbreken. Onbekend is onbemind.

De uitdaging voor de verslaggevers is dan ook bedenkelijk groot: zij moeten met een irriterend onderwerp de aandacht gaande houden en tegelijk weten aan te tonen dat zij niet de exponent van een generatie juristen zijn, die met de theoretische onderbouw van het recht elke (dan wel grotendeels) voeling hebben verloren. De lezer zal beoordelen of zij, al dan niet, in hun opzet slagen: de verslaggevers nodigen hem/haar uit geen blad voor de mond te nemen. Uit een tegenslag wordt, in de regel, meer dan uit succes geleerd.

2. Om de zich aandienende hindernissen aan te pakken, hebben de verslaggevers twee wegen bewandeld.

Eerst wordt de onderzoeksvraag van alle franjes ontdaan om tot de bevinding te komen dat de juridische kennis, die met het gezegde 'elkeen wordt geacht de wet te kennen' aan elk rechtssubject wordt toegerekend, weinig of niets om het lijf heeft.

Dit eerste deel is ongeschikt voor juristen die voor theoretisch gedoe acuut allergisch zijn.

In het tweede deel wordt stilgestaan bij de vraag hoe rechtspraak en rechtsleer omgaan met rechtssubjecten, hun raadslieden en de hoeders van het recht die, om welke reden ook, in gebreke blijven de toepasselijke rechtsregels te kennen. Hoe wordt hun zulks aangerekend en welk verweer is daarbij door hen inzetbaar? Via

* Prof. dr. I. Claeys is hoogleraar aan de Universiteit Gent en advocaat bij Eubelius te Brussel. Prof. dr. L. Cornelis is hoogleraar aan de Vrije Universiteit Brussel en advocaat bij Eubelius te Brussel. 
onder meer het zogenoemd vertrouwensbeginsel, dat tot die verweermiddelen behoort, wordt naar het rechtszekerheidsbeginsel opgeklommen, waarmee het leven van regelgevers zuur kan worden gemaakt.

Het tweede deel sluit aan op het eerste in die zin dat de toenemende complexiteit van het rechtsgebeuren, die in het eerste deel wordt behandeld, in het tweede deel naar situaties wordt omgezet, waarvan rechtspraak en/of rechtsleer menen dat die toenemende complexiteit de samenleving en/of sommige van haar leden in moeilijkheden brengt.

In een derde deel is het besluit aan de beurt.

3. Alvorens het hek van de dam te laten gaan, is erop te wijzen dat voornamelijk het eerste deel, om uiteenlopende redenen, wrevel kan opwekken.

Het werd geenszins met die bedoeling geschreven.

Ten onrechte zou eruit kunnen worden afgeleid dat de verslaggevers de les willen spellen en met het rechtsgebeuren willen afrekenen. Zij achten zich niet boven het rechtsgebeuren verheven, waaraan zij integendeel hun beroepsleven hebben verbonden.

De hierna omschreven zwakheden van het rechtsgebeuren, die op de beoefenaars ervan afkleuren, zijn derhalve ook hun deel. Het is niet eens hun bedoeling op die zwakheden kritiek uit te oefenen; wel om ze te beschrijven en te analyseren, omdat zulks toelaat te bepalen hoe er maatschappelijk mee is om te gaan.

Sommigen zullen het eerste deel als een lastige luis uit de pels willen schudden door te beweren dat dit haver voor bachelorstudenten (lees 'beginners') is, dat het rock \& roll-gehalte ervan te hoog ligt, dat het over wereldvreemde gedachten gaat, waarmee niets is aan te vangen...

De verslaggevers sluiten overigens niet uit dat zij, in een min of meer lang verleden, bij confrontatie met hiernavolgende gedachtegangen, tot een gelijksoortige bevinding (zouden) zijn gekomen.

Gelet op de, door anderen ${ }^{\mathrm{I}}$ gemotiveerd, gedane vaststelling dat de Westerse, zogenoemd democratische samenleving niet de goede richting uitgaat, ${ }^{2}$ hebben de juristen, waartoe de verslaggevers kennelijk behoren, een beperkt aantal mogelijkheden.

I Die anderen hebben dan de hoedanigheid van politicologen, sociologen, filosofen, historici, psychologen, antropologen, actuarissen, economen, enz.

2 Tenzij de teloorgang van het democratisch model, de opeenvolging van financieel-economische crisissen, de aantasting van het klimaat en van het leefmilieu, de uitputting van de - niet hernieuwbare - grondstoffen, enz. de goede richting zouden aanwijzen. 
Zij kunnen de ogen van die vaststellingen afwenden, zij kunnen - ongemotiveerd - voorhouden dat die vaststellingen feitelijke grondslag missen, zij kunnen bronnen opzoeken die een ander geluid laten horen ${ }^{3}$ of zij kunnen er rekening mee houden dat de vaststellingen de nagel op de kop kunnen slaan.

De meeste opties hebben 'het voordeel' alles bij het oude te laten. De laatstgenoemde verplicht de jurist daarentegen om zich te bezinnen over de plaats, de rol en de gevolgen van het rechtsgebeuren in de samenleving, in samenhang met de bevindingen die andere menswetenschappers aanreiken. De verslaggevers zijn die weg opgegaan. Zulks verplicht hen elementaire juridische kennis af te stoffen om ze, onbelast, aan de actuele maatschappelijke ontwikkelingen te toetsen.

Zoals gezegd, gaan zij er niet van uit dat zij daarmee nagels op de kop slaan: zij leggen - gebeurlijke - denkpistes voor, meer niet.

\section{DEEL 1: De tering}

\section{I.I Welkom in het rijk der illusies}

\subsubsection{Holle woorden}

4. Na de onderzoeksvraag een paar keer door de vingers te hebben laten glijden, blijkt zij niet zozeer betrekking te hebben op het zogenoemde adagium dat eenieder wordt geacht de wet te kennen, maar wel op de vraag naar de relevantie van kenbaarheid en dus beheersbaarheid van het privaat recht door de rechtssubjecten, er (voorlopig) van uitgaande dat zijn complexiteit toeneemt.

Wanneer de ken- of de beheersbaarheid van het (privaat)recht ter discussie staat, biedt het vermelde adagium evenwel weinig toegevoegde waarde.

5. Overigens, waarom zou de juridische kennis, die met het bestudeerde gezegde aan elkeen wordt toegeschreven, zich tot de wet beperken? De wet in de materiële betekenis van het woord is overduidelijk niet de enige formele bron van rechtsregels. Daarnaast is met jurisprudentiële rechtsregels rekening te houden.

Velen zullen daaraan, schools, de algemene rechtsbeginselen, de gewoonte, soft law, de redelijkheid en billijkheid, enz. willen toevoegen.

Omdat de erkenning van rechtsregels, die uit die andere zogenoemd formele bronnen van het recht volgen, steeds via de Hoven en Rechtbanken transiteert, wordt er hierna van uitgegaan dat er enkel wettelijke en jurisprudentiële rechtsregels

3 Die bronnen bestaan, waarbij trouwens meer dan eens de vraag rijst waarom ze bestaan. Zie onder meer N. Oreskes en E. Conway, Les marchands de doute, 2010, 523 p. Een voorbeeld van 'gif' en 'tegengif': R. Wilkinson en K. Pickett, The spirit level. Why equality is better for everyone, Londen, Penguin Books, 2010, 375, enerzijds en C. Snowdon, The spirit level delusion. Fact-checking the lefts new theory of everything, Londen, Little dice, 20Io, I7I p. 
bestaan, daarbij benadrukkend dat de jurisprudentiële rechtsregels op meerdere, van elkaar onderscheiden deductiemethoden kunnen berusten. ${ }^{4}$

Vanzelfsprekend kan het toepassingsgebied van het onderzochte gezegde niet tot wettelijke rechtsregels worden beperkt: ofschoon zulks zelden wordt benadrukt, ${ }^{5}$ moet de juridische kennis die aan elkeen wordt toegeschreven, ook de jurisprudentiële rechtsregels omvatten, waartoe de wettelijke rechtsregels, via hun toepassing door Hoven en Rechtbanken, aanleiding geven.

Er is geen goede reden te bedenken die zou toelaten de kennis van wettelijke rechtsregels te veronderstellen en die van jurisprudentiële rechtsregels te ontkennen.

6. Er moet niet op de examenperiode aan één of andere rechtsfaculteit worden gewacht om vast te stellen dat het adagium, waardoor elkeen wordt geacht de (toepasselijke) rechtsregel te kennen, enkel lachspieren kan beroeren.

Zulks geldt trouwens niet enkel voor rechtenstudenten, maar ook voor de best getrainde en de meest getalenteerde rechtsbeoefenaars: het is dan ook een illusie te denken dat jan en alleman, steeds en overal, de toepasselijke rechtsregel kent.

Het adagium blijkt een (juridische) fictie te zijn, waarmee juristen goochelen om werkelijkheidsvreemde resultaten toch een zweem van waarschijnlijkheid of aannemelijkheid te geven. Juristen zijn daarin meesters: ${ }^{6}$ 'Klaag niet over de toepassing van die rechtsregel, want $\mathrm{U}$ had die moeten kennen.'

7. Dat gezegd zijnde, wordt het adagium dus ontmaskerd als een deksel dat een ongemakkelijk potje dicht moet houden. Door van juridische kennis uit te gaan, wordt de aandacht afgeleid van de intrinsieke moeilijkheden, waardoor de rechtsregel en de rechtsbedeling worden gekenmerkt en die hun ken- en beheersbaarheid onderuit halen.

Zowel de rechtsregel als de toepassing ervan is, in beginsel, onafhankelijk van de kennis die de rechtssubjecten van de rechtsregel hebben. De rechtsregel is toepasselijk en wordt toegepast van zodra de beoordeler, die een rechter, een arbiter, een overheid, een wetenschapsbeoefenaar of een jurist kan zijn, ${ }^{7}$ vaststelt dat de toepassingsvoorwaarden ervan in het, door hem/haar aangenomen feitenrelaas verenigd zijn.

De kennis van die toepasselijkheid is, in de regel, noch een toepassingsvoorwaarde van de rechtsregel, noch een vereiste om die rechtsregel te kunnen toepassen.

4 Zie M. Van De Kerckhove, 'La jurisprudence revisitée: un retour aux sources', in Les sources du droit revisitées, VII, Limal, Anthemis, 20I2, 667-7I2.

5 Zie evenwel S. De Somer en C. Fornoville, 'Rechtspraakpublicatie anno 20II, historische beschouwingen, hedendaagse bedenkingen en toekomstperspectieven', RW 20II-20I2, 226.

6 De zgn. zekerheid van de schade en van het causaal verband zijn daarvan voorbeelden (zie hierna nr. 93)

7 Die hierna in globo als 'de beoordeler' worden aangeduid. 
Onder omstandigheden zal de miskenning van een toepasselijke rechtsregel niet aan de auteur ervan worden toegerekend, ${ }^{8}$ maar zulks laat onverlet dat de rechtsregel toepasselijk is van zodra zijn toepassingsvoorwaarden in de feiten verenigd raakten.

8. Die vaststellingen zijn, als uitgangspunt, hun gewicht in goud waard.

Zowel de rechtsregels als de ervan gemaakte toepassingen zijn immers de emanaties van openbare diensten, die - al zijn ze niet de belangrijkste - van groot maatschappelijk belang zijn.

Het positief recht en de rechtsbedeling stemmen, als openbare diensten, hun bestaan en werking niet af op het rechtssubject, dat ermee wordt geconfronteerd, maar wel op de organisatie en de handhaving van de politieke, sociale, culturele, economische ... structuur, die door een samenleving werd gekozen.

Op de organisatie en de handhaving van die gekozen samenlevingsstructuur komt het, wat die openbare diensten betreft, aan. De impact van de rechtsregel en van de rechtsbedeling op één of meerdere rechtssubjecten is daarvan de, daaraan ondergeschikte, uitwerking.

Aan de kennis van de rechtsregel en/of van zijn toepasselijkheid kan dan ook geen doorslaggevend belang worden toegekend. De toepassing van de rechtsregel dringt zich integendeel op van zodra zijn toepassingsvoorwaarden verenigd raken, omdat zulks de organisatie en de handhaving van de politieke, sociale, morele, economische... samenlevingsstructuur ten goede komt.

9. Door naar een zogenoemd veronderstelde kennis van de toepasselijke rechtsregel(s) te verwijzen, wekt het gezegde bovendien de onterechte indruk dat het rechtssubject dat niet over de veronderstelde kennis beschikt, een fout zou begaan.

Die benadering strijdt met het contractuele en buitencontractuele foutbegrip, wat de maatschappelijke relevantie van dat begrip in het gedrang brengt.

Het onderscheid tussen de contractuele resultaats- en inspanningsverbintenissen alsmede de hypothese van een wets- of rechtsregelovertreding ${ }^{9}$ buiten beschouwing latend, houdt de vaststelling van een burgerlijke fout in dat niet werd gehandeld zoals door een toerekeningsvatbaar, normaal voorzichtig en redelijk rechtssubject, in dezelfde feitelijke omstandigheden geplaatst, zou zijn gedaan, waardoor enige schade als gevolg daarvan voorzienbaar werd. ${ }^{\circ}$

Uit de enkele afwezigheid van veronderstelde juridische kennis kan derhalve niet zonder meer tot het bestaan van een burgerlijke fout worden besloten, vermits de - drie - foutvoorwaarden daaruit niet zijn af te leiden.

$8 \quad$ Zie de corrigerende leerstukken in deel 2.

9 Zie m.b.t. die begrippen: P. Van Ommeslaghe, Droit des obligations, Brussel, Bruylant, 20Io, I, p. 39-48; P. Wéry, Droit des obligations, Brussel, Larcier, 20II, I, 522-529 (inzake het onderscheid tussen inspannings- en resultaatsverbintenis); T. Léonard, 'Faute extracontractuelle et juridictions commerciales. Principes et plaidoyer pour un retour à une vision unitaire de la faute', TBH 20I3, 95I-978 (inzake de wetsovertreding).

Io O.m. T. Vansweevelt en B. Weyts, Handboek buitencontractueel aansprakelijkheidsrecht, Antwerpen, Intersentia, 2009, p. I23-I66. 
Io. Met het adagium dat elkeen wordt geacht de toepasselijke rechtsregel te kennen, is dan ook weinig aan te vangen.

Het tracht op goedkope en misleidende wijze te verklaren waarom de kennis en de kenbaarheid van de toepasselijke rechtsregel(s) door het, eronder gebukt gaande, rechtssubject er niet toe doet eenmaal zijn (hun) toepassingsvoorwaarden verenigd raakten.

De ware verklaring van het adagium is immers niet een veronderstelde juridische kennis, maar wel de maatschappelijke finaliteit van de rechtsregel en van de, daarop afgestemde rechtsbedeling. Als emanaties van openbare diensten dragen zij tot de organisatie en de handhaving van de gekozen samenlevingsvorm bij; meer is er niet aan de hand en doekjes daarrond doen meer kwaad dan goed.

\subsubsection{Smeulend vuur}

II. Indien het gezegde zich desondanks generatielang kranig heeft weten te houden, moet de verklaring in onderliggende motieven worden gezocht.

Eén ervan is ongetwijfeld 'didactisch' te noemen: elkeen wordt met veronderstelde juridische kennis om de oren geslagen om niet verder te moeten uitleggen dat niet aan de rechtsregel te ontkomen valt, eenmaal zijn toepassingsvoorwaarden in de feiten verenigd raakten. ${ }^{\text {II }}$

Het adagium werkt bovendien als bliksemafleider, vermits vermanend op een veronderstelde juridische kennis wordt gewezen. Zodoende wordt de aandacht van de intrinsieke, smeulende, dan wel oplaaiende onzekerheden afgeleid, die elke rechtsregel en zijn toepassing kenmerken en wellicht ook moeten kenmerken, omdat andere oplossingen nu eenmaal ontbreken.

I2. De kennis van de (toepasselijke) rechtsregel is daarbij slechts één bescheiden aspect van het traject, dat wordt doorlopen om tot een concrete toepassing te komen.

Het bangelijke verhaal begint met de feiten die zich, over een korte dan wel lange tijdspanne, hebben voorgedaan en tot een - al bij al - hevig conflict ${ }^{12}$ tussen rechtssubjecten hebben geleid.

Het rechtenonderwijs heeft er nauwelijks aandacht voor, maar dat laat onverlet dat het onontbeerlijk is een zo juist en zo volledig mogelijk inzicht in de feiten te krijgen, zoals ze zich chronologisch hebben voorgedaan, om de rechtsregel(s) correct te kunnen toepassen.

Het in kaart brengen van alle feiten, die zich in onderlinge interactie hebben voorgedaan, is een hachelijke, zo niet onmogelijke opdracht. De eerlijkheid gebiedt te

II Die idee komt in de Franse versie van het gezegde beter tot uiting; 'nul n'est censé ignorer la loi' drukt uit dat aan de wet/de rechtsregel niet is te ontkomen.

I2 Het conflict moet inderdaad hevig zijn om een partij ertoe aan te zetten een (externe) beoordeler te vatten. 
erkennen dat er daarbij al te veel stoorzenders opduiken, die het (zeer) onwaarschijnlijk maken dat de feiten volledig en juist kunnen worden gereconstrueerd.

13. Het resultaat ${ }^{13}$ is dat ... vrede is te nemen met een feitenrelaas, dat slechts min of meer met de werkelijke toedracht strookt.

Die vaststelling ontneemt het zogenoemd adagium het laatste greintje (feitelijke) legitimiteit.

Vermits de toepasselijke rechtsregels in functie van de vastgestelde feiten zijn te bepalen en er niet kan worden geanticipeerd op de wijze waarop de beoordeler de feiten zal (kunnen) vaststellen, moet de veronderstelde juridische kennis van het rechtssubject wel een slag in het water zijn.

Juridische kennis wordt immers pas relevant wanneer de feiten bekend zijn waarop zij kan voortgaan. Het adagium hult zich evenwel in stilzwijgen met betrekking tot de kennis van die feiten; daarop gaat het niet in. Het rechtssubject wordt m.a.w. niet verondersteld om alle relevante feiten te kennen, wat overigens niet kan verbazen. Vervolgens, desondanks, beweren dat eenieder wordt geacht de toepasselijke rechtsregel(s) te kennen, is eerder een bedroevend spektakel dan een opsteker voor de juridische trots.

I4. Het adagium moge dus in vrede rusten.

Zorgt dit eerste besluit voor toenemende juridische onrust en onzekerheid in het licht van de perceptie van een toegenomen complexiteit van het rechtsgebeuren, waardoor de voorspelbaarheid van het in rechte te bereiken resultaat terugloopt of zou teruglopen?

De meningen daarover zullen ongetwijfeld uiteenlopen: of zulks voldoende kan zijn om een onwaarschijnlijk verhaal als dat van eenieders veronderstelde juridische kennis aan het infuus te houden, is echter zeer te betwijfelen.

Het positief recht en de rechtsbedeling lijken meer gebaat bij transparantie, dan bij schijnmanoeuvres. Het is daarom beter te erkennen dat de zogenoemd veronderstelde juridische kennis geen been heeft om op te staan.

De eliminatie van de voorgestelde onderzoeksvraag is trouwens geen drama. Zij leidt integendeel naar drie andere onderzoeksvragen, die daardoor het zonlicht zien: waarom is het rechtsgebeuren complex, ${ }^{14}$ is er sprake van een toenemende complexiteit ${ }^{15}$ en, mits die toename wordt bevestigd, heeft het privaat recht middelen in huis om daaraan iets te veranderen ${ }^{16}$

I3 Zijnde het feitenrelaas, waarop de beoordeler in fine voortgaat.

I4 Zie hierna de nrs. I5-43.

I5 Zie hierna de nrs. 44-78.

I6 Zie hierna de nrs. 79-II7. 


\subsubsection{Complexiteit troef}

I5. Om tot toegenomen complexiteit te besluiten, moet de complexiteit van het rechtsgebeuren kunnen worden gemeten.

Empirisch onderzoek daaromtrent is, voor zover aan de verslaggevers bekend, beperkt. ${ }^{17}$ De conceptie van dergelijk onderzoek is een uitdaging op zichzelf.

Om de complexiteit van het rechtsgebeuren en de, gebeurlijke, toename ervan te meten, moet vooreerst de periode worden bepaald, waaraan de perceptie van toegenomen complexiteit wordt getoetst: wordt er tien, twintig, vijftig, dan wel honderd jaar in de tijd teruggegaan?

De resultaten op het vlak van toenemende complexiteit zullen manifest verschillen naargelang het gebruikte 'venster'.

Tevens rijst de vraag welke onderzoeksgroepen zijn in te schakelen: jongeren/ouderen, met welke opleiding, dan wel beroepservaring...?

I6. Het grootste obstakel is evenwel de subjectiviteit, in alle mogelijke tinten en vormen. De beoordeling dat een gebeuren complex is, kan immers sterk subjectief gekleurd zijn.

Elke jurist weet dat een startende of ontoereikende kennis van een rechtsprobleem (en van zijn feitelijke onderbouw) of van een rechtsdomein met de indruk gepaard gaat dat met een (al te) complexe juridische wereld is af te rekenen.

Nadat de daartoe vereiste inspanningen zijn geleverd (studie, opzoekingen, ervaring, enz.) en eenmaal de relevante concepten en beginselen van het eerder onontgonnen rechtsprobleem of -domein meer en meer onder de knie zijn gekregen, verdampt het complexiteitsbesef beetje bij beetje om, recht evenredig, door zelfvertrouwen en voldoening te worden vervangen.

Het spreekt voor zich dat het rechtsgebeuren voor een niet-juridisch getrainde geest een verschrikking kan/moet zijn, meteen veroordeeld als zijnde van disproportionele complexiteit.

De jurist die door een medicus een ziektebeeld en de daarop aan te sluiten behandeling uitgelegd krijgt, bevindt zich in een soortgelijke toestand.

Subjectief ingevulde complexiteit gaat aldus met het risico dan wel met de zekerheid gepaard dat daarmee veel meer over ontoereikende kennis of inzicht dan over de moeilijkheidsgraad van het rechtsgebeuren wordt gezegd.

17. Ofschoon, zoals hierna blijkt, subjectieve elementen niet volledig uit de complexiteitsbeoordeling zijn weg te cijferen, kan er toch naar worden gestreefd een aantal valstrikken te vermijden om de gebeurlijke toename van complexiteit te beoordelen.

I7 J. Dumortier, m.m.v. M. Penninckx en Y. Timmermans, 'Wie wordt nog geacht de wet te kennen?', RW I992-I993, 938 (zij verwijzen in een voetnoot naar Zwitsers empirisch onderzoek). 
Meer bepaald moet de complexiteit die, intrinsiek, zowel aan de rechtsregel als aan de rechtsbedeling eigen is, buiten beschouwing blijven wanneer de vraag ter discussie staat of het rechtsgebeuren al dan niet in complexiteit toeneemt.

Voor de intrinsieke complexiteit van het rechtsgebeuren hoeft de jurist zich overigens niet te schamen: zij is slechts een flauw afkooksel van de complexiteit die het samenlevingsgebeuren kenmerkt en die de juridische complexiteit overigens verklaart.

Om een tipje van de sluier op te lichten: het is beter de klemtoon op die complexiteit en de daarmee noodzakelijk gepaard gaande onzekerheid te leggen, eerder dan met halfslachtige drogredenen het juridische imperium op te poetsen. Wie de hierbij voorgestelde benadering volgt, moet dan wel belangstelling hebben en tonen voor het (ruimere dan strikt juridische) samenlevingsgebeuren, waarvan juristen - jammer genoeg en om uiteenlopende redenen -doorgaans denken dat zij daarvoor niet, in het bijzonder, hebben in te staan.

I8. Zowel de wettelijke als de jurisprudentiële rechtsregel wordt door complexiteit gekenmerkt.

Rechtsregels enten zich op feiten, die zich als gebeurtenissen, omstandigheden, toestanden, handelingen, enz. in de samenleving voordoen.

Ten aanzien van die feiten neemt de bevoegde overheid stelling: zij wil die feiten, in het belang van de samenlevingsstructuur, hetzij vermijden, hetzij aanmoedigen. Om de hiervoor toegelichte redenen gebruikt de bevoegde overheid daartoe wetten in de materiële betekenis, alsmede jurisprudentiële rechtsregels.

De complexiteit van het rechtsgebeuren zit in de verschillende stadia gebakken, die worden doorlopen om tot een rechtsregel en/of zijn toepassing te komen.

De gevolgde werkwijze verschilt weliswaar naargelang het resultaat een wettelijke, dan wel een jurisprudentiële rechtsregel is, maar wordt steeds door complexiteit gekenmerkt.

Ze hebben verder met elkaar gemeen dat de feiten in de hiervoor omschreven betekenis, de rechtsregelvorming en de rechtsregeltoepassing voorafgaan en haar bepalen. Die feiten en hun beoordeling aan de hand van gangbare waarden worden, traditioneel, de materiële bronnen van het recht genoemd.

\section{a) Complexe wetgeving}

\section{a.1 De finaliteit van de wettelijke rechtsregel}

I9. Een scherp en volledig inzicht in de zich voordoende, dan wel beoogde feiten, is voor de overheid een onontbeerlijke voorwaarde om tot een daarop aansluitende, wettelijke rechtsregel te komen, die de door haar nagestreefde maatschappelijke impact kan hebben.

Op papier is dit kinderspel: verzamel de relevante feiten en bepaal, in functie daarvan, de gepaste rechtsregel om het gewenste maatschappelijke effect te bekomen.

Zulks is veel gemakkelijker gezegd dan gedaan. De genesis van de wettelijke rechtsregel overtreft niet enkel, in ruime mate, het strikt juridische: er duiken daarbij ook tal van knelpunten op, waarmee behoedzaam is om te springen. 
Vooreerst zijn de in aanmerking te nemen feiten niet van het maatschappelijke kader los te koppelen, waarin ze zich voordoen. Feiten worden niet louter vastgesteld; aan hun vaststelling zit, onlosmakelijk, een beoordeling vast, die wordt bepaald door een - moeilijk te doorgronden - mengsel van onder meer politieke, sociale, morele, economische en/of juridische overwegingen, die de wetgever, al dan niet onder invloed, aaneenrijgt, omdat hij meent dat ze de samenleving dienen.

Zijn waarneming van feiten is derhalve door maatschappelijke overwegingen gekleurd: de feiten ontlenen daaraan hun belang.

Hetzelfde geldt met betrekking tot de door de wetgever nagestreefde gevolgen: eenmaal gekaderd en geëvalueerd worden de feiten in een juridisch keurslijf gegoten om er - welbepaalde - rechtsgevolgen aan te koppelen. Die rechtsgevolgen worden eveneens gedetermineerd door gangbare, onder meer politieke, sociale, morele, economische en/of juridische opvattingen en bekommernissen, zoals zij door de wetgever worden gezien.

20. De wijze waarop wetgevers zich actueel van hun regulerende taak plegen te kwijten, kan de indruk wekken dat de complexiteit (en de daarmee gepaard gaande moeilijkheidsgraad) van het wetgevend proces wordt overroepen.

Het aureool van delicaat maatwerk is vervangen door een onnauwkeurig afgestelde productie aan de lopende band, met resultaten die eerder op prototypes, dan op afgewerkte producten lijken.

Het kind met het badwater weggooien is evenwel zelden een oplossing.

Kwaliteitsvolle wettelijke rechtsregels blijven een artisanale aanpak vergen, waarbij de bevoegde overheid, die zich daartoe de vereiste middelen ter beschikking moet stellen, de vinger op de pols van de maatschappelijk gangbare, onder meer politieke, sociale, morele, economische en/of juridische opvattingen en bekommernissen moet houden. Zij kleuren immers niet enkel de feiten, maar bepalen ook de, daaraan te verbinden rechtsgevolgen.

De omstandigheid dat zulks, tegen beter weten in, door sommige wetgevers en juristen niet meer ernstig wordt genomen, verandert de weg niet om tot kwaliteitsvolle rechtsregels te komen.

Wie van dat patroon afwijkt, draagt de verantwoordelijkheid van de ermee gepaard gaande neveneffecten, zoals de aantasting van het krediet waarover wetgevers moeten beschikken om met succes op de maatschappelijke reacties te kunnen anticiperen, waarmee elke regelgeving gepaard gaat.

Een wetgevend initiatief met averechtse gevolgen of met uitzicht op niet vooraf geneutraliseerd ontwijkingsgedrag, kan als kiespijn worden gemist. Hoe sneller en ondoordachter een wetgevend initiatief in elkaar wordt gebokst, hoe groter het risico dat de wet niet ernstig wordt genomen en dat leemten gebruikt kunnen worden om de wetgever een neus te zetten. 
Vermits de toekomst onkenbaar is zolang hij niet, via het korte heden, verleden is geworden, bestaat het anticiperen op toekomstige ontwikkelingen in het afwegen van, omzichtig en evenwichtig, in kaart gebrachte waarschijnlijkheden. Er bestaat een onoverbrugbaar verschil tussen het omzichtig afwegen van feitelijk ondersteunde waarschijnlijkheden en het voortgaan op de natte vinger, om van buikgevoel te zwijgen.

2I. Kortom, ook wanneer de wetgever de tijd neemt en de passende middelen inzet om tot een kwaliteitsvolle wettelijke rechtsregel te komen, gesneden op de maat van de maatschappelijk gangbare, onder meer politieke, sociale, morele, economische en/of juridische opvattingen en bekommernissen en uitzicht gevend op daarmee strokende rechtsgevolgen, die zelfs ten opzichte van ontwijkingsgedrag kunnen worden afgedwongen, blijft vast te stellen dat de genesis van de wettelijke rechtsregel, naar feitelijke onderbouw en nagestreefde objectieven, een bijzonder complex karakter heeft.

Voor het rechtssubject en voor de jurist die naderhand met die rechtsregel te maken krijgen, leidt dit tot de volgende, onaantrekkelijke boodschap: om de inhoud, de zin en de draagwijdte van een wettelijke rechtsregel te doorgronden en, in functie daarvan, zijn toepasselijkheid te kunnen beoordelen, is kennis van die complexe feitelijke onderbouw en van de ermee nagestreefde objectieven onmisbaar en bepalend.

De complexiteit van het wetgevend proces is immers in elke wettelijke rechtsregel verankerd.

22. De complexiteit krijgt zelfs angstaanjagende proporties naarmate de persoon, al dan niet jurist, die met een wettelijke rechtsregel wordt geconfronteerd, minder inzicht in of kennis van de, door wetgevers beoordeelde feitelijke onderbouw en/of van de ermee nagestreefde objectieven heeft.

Omgekeerd wordt het interpretatieproces vergemakkelijkt en wordt de complexiteit tot haar ware dimensie herleid naarmate die persoon het verband tussen de wettelijke rechtsregel en de maatschappelijke gangbare, onder meer politieke, sociale, morele, economische en/of juridische opvattingen en bekommernissen weet te leggen, die de feitelijke onderbouw van de wet zijn en haar objectieven tastbaar maken.

Euforie is daarbij evenwel nooit op haar plaats: zelfs een jurist die over alle relevante maatschappelijk gangbare, onder meer politieke, sociale, morele, economische en/ of juridische inzichten, in de juiste, onderlinge verhouding zou beschikken ${ }^{18}$ om het verband tussen de vastgestelde feiten, de beoogde rechtsgevolgen en de daarop gesteunde wettelijke rechtsregel te leggen, heeft immers nog geen vrije doorgang.

Een bijkomende moeilijkheid en niet de minste duikt op. Het zijn immers niet de inzichten van het rechtssubject, van de jurist en, ultiem, van de beoordeler die de 
inhoud, de zin en de draagwijdte van de wettelijke rechtsregel bepalen, maar wel die van de bevoegde wetgever, die het wetgevend initiatief heeft genomen.

\section{a.2 Wat de interpretatie ervan maakt}

23. Zoals alle juristen (horen te) weten, is de bedoeling van de wetgever de vaste leidraad bij de interpretatie van wettelijke rechtsregels.

De technieken om die bedoeling, post factum, te achterhalen zijn eveneens welbekend: achtereenvolgend de tekstanalyse, waarbij taalkennis primordiaal is, de voorbereidende werken, de algemene economie van de wet, de 'ratio legis' en de maatschappelijke context waarin het wetgevend initiatief zich voordeed. ${ }^{19}$

Die technieken worden idealiter met elkaar gecombineerd om tot een onderbouwd besluit te komen, waarbij het rijtje in de juiste volgorde is af te lopen.

De kans dat de rechtsbeoefenaar zijn/haar inzichten aan de wetgever toerekent, groeit immers exponentieel, naarmate van de wettekst meer en meer afstand wordt genomen.

24. Overigens, en daarover gaat het, is de substitueerbaarheid van inzichten, binnen welbepaalde grenzen, voor de rechtsbeoefenaar steeds een optie. Anders gezegd, bij de interpretatie van een wettelijke rechtsregel is zoveel meer mogelijk dan zich louter aan de bedoeling van de wetgever te houden. Het is, in vele gevallen, een koud kunstje om over die bedoeling twijfel uit te drukken om vervolgens, op eigen inzichten voort te gaan: 'ni vu, ni connu'.

Er is veel zelfcontrole, zelfdiscipline en/of nederigheid nodig om daaraan niet toe te geven. Wie de aard van het beestje kent, weet dat zulks voor de menselijke natuur, zelfs in de gedaante van een jurist, regelmatig te hoog is gegrepen.

Niet enkel de ontstaansgeschiedenis van de wettelijke rechtsregel, maar ook de latere interpretatie van die rechtsregel gaan aldus onder complexiteit gebukt.

Het voorgaande leidt geenszins tot afkeuring; er wordt enkel verduidelijkt dat de kwaliteit van de rechtsregel en van zijn toepassing onder meer in het kader van het interpretatieproces op de maat van het - begrensde - menselijke vermogen is gesneden. Dat menselijk vermogen ligt aan de wieg zowel van het ontstaan als van de toepassing van die rechtsregel. Ongeacht de (mogelijk ondermaatse) kwaliteit, worden daarbij steeds complexe processen doorlopen, die ondoorzichtelijker worden naarmate van minder politieke, sociale, morele, economische en/of juridische kennis wordt uitgegaan, dan wel toenemend van de initiële bedoeling van de wetgever afstand wordt genomen. Beide tendensen gaan er evenwel, jammer genoeg, sterk op vooruit.

I9 W. Van Gerven, Algemeen deel, in Beginselen van Belgisch privaatrecht, I, Antwerpen, Standaard WA, I973, 5I-6I. 
25. Zijn de recente generaties van juristen beter (of slechter) opgeleid om met de materiële bronnen van het recht om te gaan, dan wel beter (of slechter) getraind om de bedoeling van de wetgever in ere te houden?

Gelet op het onderwijsaanbod van de rechtenfaculteiten moet worden vastgesteld dat kennelijk veel meer heil van de technische, formele bronnen van het recht, dan van de, door de samenleving bepaalde en nagestreefde materiële bronnen van het recht wordt verwacht.

Investeren in juridische techniek is vanzelfsprekend een vereiste wanneer het op de vorming van juristen aankomt, maar of zulks ten koste moet gaan van de algemene vorming en dus van voeling met de samenleving, is de echte vraag. Een aantal zogenoemde reflectievakken op het einde van het curriculum vullen de leemte niet. Om te reflecteren is algemene en brede basiskennis vereist; daar nijpt het schoentje.

Leren de studenten op de universiteitsbanken de maatschappelijke functie aan die zij, ongeacht de gekozen beroepsweg, zullen hebben? Leren ze omgaan met de toestand van kennisasymmetrie waarin zij zich permanent en, naarmate hun kennis en ervaring toeneemt, intensiever bevinden? Leren ze de signalen van de daarmee gepaard gaande belangenconflicten ontcijferen? Weten ze met belangenvermenging in het reine te komen?

Ze weten, overduidelijk, meer - althans op het vlak van de juridische techniek - over rechtsregels van allerhande slag, die op anderen zijn toe te passen en/of door anderen zijn na te leven, dan over de rol van (maatschappelijke) betekenis die hun toevalt.

Het recht wordt hun voorgesteld als een instrument om hun levenswandel te structureren. Het maatschappelijke kader en de openbare dienstverlening die zowel het recht als de rechtsbedeling kenmerken, worden daarbij slechts uitzonderlijk vermeld en toegelicht. Het resultaat daarvan draait noodzakelijk uit op een zeer eenzijdige kijk op het rechtsgebeuren, namelijk één waarin het eigenbelang van de jurist, via dat van de opdrachtgever, centraal staat.

b) Jurisprudentiële complexiteit

b.1 Op de feiten komt het aan

26. Alweer, op papier, is er niets moeilijks aan het rechtspreken.

Bepaal de feiten die zich hebben voorgedaan (de thesis) en - op grond daarvan - de toepasselijke rechtsregels (de antithesis), pas vervolgens die rechtsregel(s) op die vastgestelde feiten toe (de synthese) en ... recht is geschied.

Onder die vereenvoudiging gaat een wereld schuil, die, naar complexiteit gemeten, hoge toppen scheert.

Het lange en wisselvallige verhaal van de rechtsbedeling begint met de vaststelling van de feiten zoals ze zich hebben voorgedaan: andermaal veel gemakkelijker gezegd dan gedaan. 
Ofschoon die feiten voor de synthese (de beoordeling, het dispositief) bepalend zijn, is onmogelijk te garanderen dat alle feiten, in hun juiste chronologie en interactie, aan bod komen.

Het feitenrelaas waarop de beoordelers moeten voortgaan, is meestal een - vaak zeer gebrekkige - reconstructie van de werkelijke toedracht, die voor eens en altijd - onder meer wegens het tijdsverloop, door de wens om gelijk te krijgen en ook omwille van gebrek aan inzet van de betrokkenen - ontoegankelijk is geworden.

27. De geschilvoerende partijen zijn bijzonder slecht geplaatste getuigen om de feiten die tot het dispuut aanleiding gaven, weer te geven.

Hun geschil is, in vele gevallen, te herleiden tot uiteenlopende visies omtrent feiten die zich (al dan niet) hebben voorgedaan. Hun belangen en geheugen spelen de partijen lelijk parten bij de weergave van die feiten, ook wanneer zij zich daarvan niet volledig bewust zijn.

Hun dikwijls zeer uitgesponnen en door emoties doordrongen verhalen, overtuigd van gelijk, worden vervolgens door hun raadslieden samengevat. Die samenvattingen leiden tot (min of meer goed gestructureerde) feitelijke toelichtingen, bestemd om aan de beoordeler te worden voorgelegd.

Gelet op die finaliteit is niet de feitelijke toelichting, maar wel de daaraan toekomende overtuigingskracht voor de partij en haar raadsman leidinggevend. Die overtuigingskracht is voor hen bepalend, omdat zij ernaar streven het gevorderde (de toekenning, dan wel de afwijzing van de vordering(en)) te bekomen.

De feiten worden in die optiek door hen belicht en gesmaakt.

Aan de beoordeler worden aldus weinig meer dan geselecteerde feiten voorgelegd, afgezien van de vaststelling dat de zorg waarmee de feiten worden vergaard en naar pertinentie worden geëvalueerd, van partij tot partij, van raadsman tot raadsman verschilt. De kans dat het aan de beoordeler voorgelegde feitenrelaas werkelijkheidsgetrouw is te noemen, kan dan ook niet hoog worden ingeschat.

28. Aan de beoordeler komt vervolgens de moeilijke taak toe om orde in de opgediste feiten te brengen. Daarvan kan mogelijk veel worden verwacht, maar in elk geval niet dat het tendentieuze of minstens onvolledige feitenrelaas van elke partij door hem tot een synthese wordt omgeturnd, die, als bij wonder, de waarheid en niets anders dan de waarheid aan het licht zou brengen.

De samenvatting van de feiten die door de beoordeler op zijn/haar beurt wordt uitgewerkt, heeft die ambitie niet: uitgaande van het beschikkingsbeginsel ${ }^{20}$ nemen de partijen en niet de beoordeler de verantwoordelijkheid om de, naar hun oordeel, relevante feiten in rechte aan te voeren.

Daarop kan de beoordeler voortbouwen. Onder voorbehoud van de incidentie van rechtsregels van gebiedend of verbiedend recht $^{21}$ hoeft hij/zij zich niet af te vragen

20 B. Allemeersch, Taakverdeling in het burgerlijk proces, Antwerpen, Intersentia, 2007, I3-27.

2I Zie hierna nr. 9I. 
of de partijen een voldragen, dan wel een vertekend beeld van de feiten geven. Uitgaande van de voorgelegde feiten zoekt de beoordeler uit of daarvan, in overeenstemming met de rechtsregels inzake de bewijslastverdeling, door hen het bewijs wordt geleverd.

Inzake bewijs heeft de beoordeler niet enkel de macht om onderzoeksmaatregelen te bevelen, maar ook een zeer aanzienlijke beoordelingsvrijheid, ongeacht het (de) aangevoerde bewijsmiddel(en).

Die vrijheid vindt haar oorsprong in de alles overrompelende feitelijke vermoedens $^{22}$ die in de bewijsbeoordeling bepalend zijn, ook wanneer het erop aankomt de bewijswaarde van onder meer geschriften, getuigenissen, verklaringen en andere te beoordelen.

Bewijsmiddelen moeten, voornamelijk wanneer zij met betrekking tot rechtshandelingen worden aangewend, vaak aan vormvoorwaarden voldoen. Die vormvoorwaarden zijn slechts een eerste bewijsdrempel. Daaropvolgend dient er zich een tweede, minder bekende maar gewichtiger, drempel aan die erin bestaat dat wordt bepaald of en in welke mate aan het bewijsmiddel geloof is te hechten. Op een paar uitzonderingen $\mathrm{na}^{23}$ bepalen feitelijke vermoedens de bewijswaarde die de beoordeler aan het bewijsmiddel zal toekennen.

Om van het zekere feit (het voorgelegde bewijsmiddel) naar het onzekere feit (de geloofwaardigheid ervan) over te stappen ${ }^{24}$ kan de beoordeler immers enkel op feitelijke vermoedens voortgaan.

29. Het mist grondslag te denken dat elke beoordeler, in dezelfde omstandigheden geplaatst en dus geconfronteerd met dezelfde feiten en bewijsmiddelen, op grond van feitelijke vermoedens, noodzakelijk tot hetzelfde besluit inzake bewijs komt.

Daarvan uitgaan, sust de gemoedsrust, meer niet.

De weg die het zekere van het onzekere feit scheidt en op grond waarvan de beoordeler vervolgens al dan niet zal aannemen dat het onzekere feit voortaan rechterlijk zeker is te noemen, ligt bezaaid met - bewust of onbewust - in stelling gebrachte, persoonlijke waardeoordelen, die de uitkomst van de gedachtegang, door de jurist als een feitelijk vermoeden omschreven, bepalen.

De omstandigheid dat die beoordeling, in het kader van een gewoon of zelfs buitengewoon rechtsmiddel, kan worden overgedaan, verandert niets aan die vaststelling. Ook die beoordelers zullen immers een beroep op feitelijke vermoedens moeten doen die op hun waardeoordelen steunen, waardoor wat slechts (on)waarschijnlijk is, als juridische zekerheid wordt voorgesteld.

22 M.b.t. feitelijke vermoedens zie o.m. B. Cattoir, Burgerlijk bewijsrecht, in APR, Mechelen, Kluwer, 20I3, 43I-448; B. Samyn, Privaatrechtelijk bewijs, Gent, Story-scientia, 20I2, 368-37I; P. Van Ommeslaghe, o.c., III, 24I6-2422.

23 Zie o.m. B. Cattoir, o.c., 227 e.v.

24 Volgens artikel $\mathrm{I} 349 \mathrm{BW}$ is het (feitelijk) vermoeden een 'gevolgtrekking die (...) de rechter afleidt uit een bekend feit om tot een onbekend feit te besluiten'. 
30. De in de tijd onmeetbare overstap van aangevoerd tot bewezen feit is nogmaals een bijzonder complex proces, dat meer van de persoonlijkheid van de beoordeler dan van het voorgelegde bewijsmateriaal afhankelijk is. De partijen en hun raadslieden zullen de beoordeler, vanzelfsprekend, willen en mogelijk kunnen beïnvloeden, maar de beslissing met betrekking tot elk te bewijzen feit komt steeds aan die beoordeler toe.

Zijn/haar beslissingen bepalen dus hoe het, door de partijen opgehemelde feitenrelaas de eindstreep haalt: feiten die door de beoordeler als onbewezen worden afgewezen, ${ }^{25}$ komen niet langer in het stuk voor.

De geschiedenis van het geschil wordt met andere woorden in functie van de door de partijen aangevoerde feiten en bewijsmiddelen en van de beoordeling van hun bewijswaarde ge- of herschreven.

Doekjes zijn ook hier overbodig; het besluit verdraagt het licht. Tenzij voor de beoordeler is de uitkomst van de bewijswaardebeoordeling en derhalve van de feiten die de beoordeler in aanmerking neemt, zo goed als onvoorspelbaar, al kan op grond van de maatschappelijk gangbare waardeoordelen mogelijk het risico van enige voorspelling worden genomen.

Naast het eindresultaat is evenwel niet te kijken: de feiten op basis waarvan recht wordt gesproken, zullen zelden of nooit een getrouwe weergave van de feiten zijn zoals zij zich daadwerkelijk hebben voorgedaan en waardoor het geschil is ontstaan.

3I. Dat alles is nog steeds geen reden om het kind met het badwater weg te gooien: een beter of overtuigender resultaat ligt immers niet in het verschiet. Bij afwezigheid van registratie van alle feiten, wat op zichzelf een betwistbaar idee zou zijn dat het met het EVRM aan de stok zou krijgen, wordt van de rechtsbedeling het onmogelijke gevraagd wanneer ervan wordt verwacht dat zij de waarheid in ere zou herstellen of, nog sterker, zou laten triomferen.

Het is beter daaromtrent ontgoocheling te voorkomen door toe te geven dat een dergelijk objectief, om de hiervoor toegelichte redenen, buiten de actieradius van de rechtsbedeling moet vallen.

Zelfs dubbelzinnigheid op dat vlak zorgt voor misverstanden: het is daarom evenzeer af te raden om het resultaat van de rechtsbedeling als de zogenoemd juridische waarheid voor te stellen.

Die omschrijving maakt mogelijk voor juristen duidelijk dat het om een ersatz-waarheid gaat, maar oningewijden zien de woordspeling over het hoofd en voelen zich, wanneer zij de vergissing inzien, tweemaal bekocht.

25 De vaststelling dat een feit onbewezen blijft, houdt niet in dat het aangevoerde feit zich niet heeft voorgedaan. Het betekent slechts dat met dat feit verder geen rekening wordt gehouden; het wordt uit het feitenrelaas gelicht, dat daardoor een ander uitzicht krijgt. 


\section{b.2 De toepassing van de rechtsregel: geen makkie}

32. De draad met het kramiekige feitenrelaas terug opnemend, wordt duidelijk dat de rechtsbedeling - die de hoop op te achterhalen waarheid moet laten varen - het zelfs aartsmoeilijk heeft om te garanderen dat het recht zal zegevieren.

Als het feitenrelaas ver van de werkelijke toedracht kan liggen, is er immers rekening mee te houden dat op basis van een gereconstrueerd (onvolledig, onjuist) feitenrelaas aan rechtsregels wordt gedacht die mogelijk buiten beschouwing hadden moeten blijven, indien alle feiten gekend en bewezen zouden zijn of, omgekeerd, dat, in die hypothese, rechtsregels worden genegeerd die zich hadden opgedrongen.

Zelfs wanneer vrede wordt genomen met het in rechte gereconstrueerde feitenrelaas, blijft het nog van naïviteit getuigen te denken dat de bepaling van de daarop toepasselijke rechtsregels kinderspel zou zijn.

De feiten vaststellen, hoe wispelturig reeds, is nog iets anders dan ze in functie van de toepassingsvoorwaarden van één of meerdere, in de balans liggende, rechtsregels kwalificeren.

33. Ook wanneer buiten beschouwing wordt gelaten dat de toepassingsvoorwaarden van de rechtsregel vaak onnauwkeurig zijn omschreven dan wel het voorwerp van jurisprudentiële of doctrinale meningsverschillen kunnen zijn, vergt de kwalificatie van de in aanmerking genomen feiten een gerichte interpretatie door de beoordeler. Zoals bij interpretatie steeds het geval is, zitten daarbij waardeoordelen aan het stuur.

De uitkomst van het kwalificatieleerstuk wordt bepaald door het door de beoordeler gewenste resultaat (de beschikking), dat niet louter op te kwalificeren feiten maar ook en onvermijdelijk op zijn/haar waardeoordelen berust.

Alerte lezers zullen overigens terecht opwerpen dat het kwalificatiespook zich reeds bij de vaststelling van de feiten en bij de bewijsbeoordeling in de debatten kan mengen/mengt.

34. De bescherming die in het kader van het interpretatieproces aan de partijen en hun raadslieden toekomt, strekt er niet toe om de werkelijke toedracht, de waarheid of zelfs het recht (in globo), in de mate van het mogelijke, te laten zegevieren, maar wel om, weze het onrechtstreeks, enige greep op het interpretatieproces van de beoordeler te krijgen.

Van de beoordeler wordt gevergd dat hij/zij bij de vaststelling, de bewijsbeoordeling en de kwalificatie van de feiten de daartoe gebruikte stukken ${ }^{26}$ niet doet liegen door er een inhoud, zin of draagwijdte aan te geven die er onverenigbaar mee is. Aan het stuk mag niets worden toegeschreven dat er niet in voorkomt of worden ontnomen dat erin voorkomt. Die beoordeling vergt andermaal interpretatie.

26 In de ruime betekenis van het woord, elke drager van informatie; zie o.m. B. Cattoir, o.c., I56-I57, nrs. 293-294. 
De voornaamste begrenzing van het interpretatiegeweld is evenwel in de motiveringsverplichting gelegen. Door de beoordeler met middelen (standpunten) te confronteren die tot gedachtegangen (feitelijke vermoedens) uitnodigen, dan wel omgekeerd tegenspreken, en hem/haar ertoe te verplichten uit te leggen waarom een welbepaalde gedachtegang niet dan wel toch wordt gevolgd, verhoogt de kans dat de beoordeler (eventueel na aanwending van een rechtsmiddel) tot de bevinding komt dat de gedachtegang waarop hij/zij (op grond van waardeoordelen) zou willen voortgaan, geen steek houdt.

Via de motiveringsvereiste wordt een ingewikkeld en complex steekspel tussen de partijen en hun raadslieden enerzijds en de beoordeler anderzijds mogelijk. ${ }^{27}$ Motivering is het onontbeerlijk sluitstuk van de tegenspraak, die haar grondslag in de rechten van verdediging vindt.

De finaliteit daarvan, het moet nogmaals worden benadrukt, is niet te zoeken in het achterhalen van de 'waarheid' of in de garantie dat de 'juiste' regel wordt toegepast, maar wel in de begrenzing van de - hoe dan ook nog steeds zeer aanzienlijke - interpretatievrijheid van de beoordeler.

35. De vaststelling, de bewijsbeoordeling en de kwalificatie van de feiten wijzen steeds in een en dezelfde richting: de persoon van de beoordeler, die veel meer dan de feitelijke of juridische 'waarheid' centraal in de rechtsbedeling staat.

Vermits aan de persoon van die beoordeler niets menselijks vreemd is, kan het beste en het minder goede worden verwacht. Er zijn overal opgewekte en neerslachtige, gemotiveerde en futloze, verstandige en minder verstandige, optimistische en pessimistische geesten aan te treffen. Beoordelers ontsnappen daaraan niet.

De energie of de domper van de beoordeler blijft trouwens bepalend, ook wanneer, uitgaande van de vastgestelde, bewezen en gekwalificeerde feiten, het rijk van de rechtsregels wordt betreden.

$\mathrm{Al}$ hebben de beoordelers - in grote lijnen - veelal een gelijkaardige scholing doorlopen, hun doorzicht, vernuft, kennis, ervaring, werkkracht, inzet, enz. zijn en blijven ongelijk verdeeld.

Het daardoor bepaalde (rechts)denken van de beoordeler laat zijn/haar keuze van de toepasselijke rechtsregel(s) en hun aanwending niet onberoerd, eenmaal de feiten vastgesteld en bewezen zijn verklaard. Het resultaat is de allerindividueelste uitdrukking van zijn/haar goede en minder goede kenmerken.

36. Zoals de feiten en het bewijs behoeven rechtsregels immers interpretatie om te worden toegepast. Afgezien van de persoonlijke interpretatie door de beoordeler ${ }^{28}$

27 Het is opmerkelijk dat die grondwettelijke verplichting (artikel I49 Grondwet) niet alsdusdanig wordt hernomen door G. Rommel, L'art de juger. A l'écart de Montquestieu, Brugge, die Keure, 2008, I69 p., zie p. VIII.

$28 \mathrm{Al}$ dan niet tot het zgn. beleid van de rechter (feitenbeoordeler) veredeld (zie W. Van Gerven, Het beleid van de rechter, Antwerpen, Scriptoria, I973, I67 p.). 
bestaan er bovendien inzake de inhoud, de zin en draagwijdte van rechtsregels tal van meningsverschillen.

Wie rechtspraak en rechtsleer raadpleegt, komt tot de jammerlijke vaststelling dat ze door meningsverschillen worden overwoekerd. De toepassingsvoorwaarden van de rechtsregels blijken namelijk niet, dan wel onnauwkeurig te zijn omschreven, waardoor aan de botsende belangen van de rechtssubjecten, die de juristen optimaal in stelling weten te brengen, de vrije loop wordt gegeven.

In deze wirwar van zienswijzen en botsende belangen moet de beoordeler zijn/haar weg vinden: elke beoordeler geeft daarop een eigen antwoord, in functie van zijn/ haar persoonlijkheid.

\section{b.3 Het licht door de tunnel: de beoordeler}

37. Een andere onbekende van formaat maakt zijn opwachting: hoever reikt de kennis van het (positief) recht in hoofde van de beoordeler?

'Da mihi factum, dabo tibi ius' en vooral 'iura novit curia' klinken beloftevol en bemoedigend, ${ }^{29}$ maar waar staan die adagia uiteindelijk voor? Zij verwijzen niet naar een absolute, een uitstekende of zelfs een goede kennis van het recht, zoals door het bestaan van rechtsmiddelen wordt bevestigd.

De juridische kennis waarnaar de adagia verwijzen, is die van de beoordeler op één bepaald moment van zijn/haar levensloop. Die - punctuele en dus relatieve - kennis is de vrucht van natuurlijke, sociale en individuele componenten. Over de vraag of alles, zo niet veel gedetermineerd is, dan wel of aan de vrije wil al dan niet een rol van betekenis toekomt, bestaan - zoals bekend is - zeer uiteenlopende zienswijzen. ${ }^{\circ}$

Hoe dan ook, natuurlijke, sociale en individuele componenten - in wisselende verhoudingen - bepalen de kennis die de beoordeler op het moment van de beslissing ter beschikking heeft.

Kortom, gelet op al die variabelen zal ook de perceptie van de rechtsregel door de beoordelers niet uniform kunnen zijn.

Excessieve op(mis)vattingen ${ }^{31}$ zullen kunnen worden gecorrigeerd. ${ }^{32}$ Binnen de formele grenzen van wat in het rechtsgebeuren 'redelijk' wordt geacht, spat de rechtsregel evenwel uiteen in een groot aantal klonen, in functie van de kennis van de beoordelers of hun verbeelding daaromtrent.

De rechtsregel blijft uiterlijk onveranderd, één en ondeelbaar, maar wordt door de beoordelers in uiteenlopende gedragsregels gewrongen, die door de toepassingen die zij ervan maken tot leven komen.

29 Zie daarover o.m. B. Allemeersch, o.c., I77-I96.

30 D. Swaab, Wij zijn ons brein. Van baarmoeder tot alzheimer, Amsterdam, Contact, 20II, 480 p.

3 I Wat andermaal interpretatie vergt, zoals immer, een mijnenveld.

32 Door middel van gewone dan wel buitengewone rechtsmiddelen die moeten worden aangewend om tot rechtzetting te kunnen leiden. 
38. Het kan dan ook niet verbazen dat de laatste etappe in de rechtsbedeling, zijnde de toepassing van de geïdentificeerde rechtsregel(s) (of wat daarvan overblijft) op de vastgestelde, bewezen en gekwalificeerde feiten en de daarmee bereikte beslissing, op haar beurt niet ver van dezelfde complexe boom valt.

Inzicht opbouwend in functie van de, door hem/haar vastgestelde, bewezen geachte en gekwalificeerde feiten, wordt dat inzicht door de beoordeler doorlopend aan zijn/haar kennis van de rechtsregels getoetst om uit te zoeken welke rechtsregels in dat feitelijk kader - al dan niet - dienend zijn.

Feitenconstructie, rechtsregelselectie en besluitvorming zijn, althans in theorie, chronologisch uit elkaar te houden. In werkelijkheid lopen ze in het rechtsbedelingsproces door elkaar. In theorie moet het ene aspect onbesmet op het andere onbesmet voortbouwen; in werkelijkheid bepaalt het door de beoordeler gewenst geachte resultaat niet zelden zijn/haar feitenreconstructie (met inbegrip van de bewijs- en kwalificatieaspecten) en rechtsregelselectie. ${ }^{33}$

Wie moeite heeft om aan dergelijke kronkels - die onvermijdelijk blijken te zijn - het predicaat 'complex' toe te wijzen, moet toelichten wat er nog bijkomend nodig zou zijn om tot dat besluit te komen.

\section{b.4 Rechtspraak, redder in nood?}

39. Hoe opmerkelijk dat ook is, de - al bij al - ten aanzien van de formele uitgangspunten povere kwaliteitsgarantie van de rechtsbedeling blijkt toch de bakermat van jurisprudentiële rechtsregels te zijn die op nog verdergaand rechterlijk beleid wijzen. ${ }^{34}$

In beginsel kan de beoordeler geen uitspraak doen bij wijze van algemene en als regel geldende beschikking. ${ }^{35}$

Vermits rechtsregels, althans in de Belgische rechtstraditie, algemeen, ${ }^{36}$ abstract $^{37}$ en duurzaam ${ }^{38}$ moeten zijn, afgezien van de vereiste dat zij van een daartoe bevoegde overheid moeten uitgaan, kan een rechterlijke uitspraak, die individueel, concreet en punctueel is, per definitie niet als rechtsregel gelden.

33 Niet enkel beoordelers in het kader van de rechtsbedeling handelen met 'the end in mind'; de aan de beoordeler daarmee geboden mogelijkheden komen onder meer aan bod in F. Evers en P. Lefranc (eds.), Kiezen tussen recht en rechtvaardigheid, Brugge, die Keure, 2009, 263 p. Genuanceerder is P. Scholten, De greep van de wetgever op de rechter, Brugge, Die Keure, 20II, 299 p.

34 Zie m.b.t. de rol van de rechtspraak als formele rechtsbron: W. Van Gerven en S. Lierman, Algemeen deel. Veertig jaar later, in Beginselen van Belgisch privaatrecht, I, Mechelen, Kluwer, 20I0, 26I-27I; M. Van De Kerckhove, 'La jurisprudence revisitée: un retour aux sources', in Les sources du droit revisitées, II, Limal, Anthemis, 20I2, 667-7I2; T. Hachez, 'Les sources du droit: de la pyramide au réseau et vice versa', in Les sources du droit revisitées, IV, Limal, Anthemis, 2012, 77-80.

35 Artikel 6 Gerechtelijk Wetboek.

36 De algemeenheid garandeert de gelijke behandeling van de rechtssubjecten.

37 Het abstracte karakter garandeert eveneens de gelijke behandeling van de rechtssubjecten.

$3^{8}$ De duurzaamheid draagt bij tot de handhaving van het door de rechtsregel beoogde samenlevingsmodel. 
De relativiteit van het gezag van gewijsde en van de bindende kracht van de uitspraak drukt niets anders uit. ${ }^{39}$

Het mechanisme dat toelaat om desondanks tot het bestaan van jurisprudentiële rechtsregels te besluiten die door algemeenheid, abstractie en duurzaamheid zijn gekenmerkt, kan dan ook geen eenvoudig verhaal zijn.

40. Jurisprudentiële rechtsregels concretiseren het onderling verband dat meerdere uitspraken van beoordelers, genomen op grond van vergelijkbare feiten en van 'dezelfde' rechtsregels, kenmerkt.

De jurisprudentiële rechtsregel brengt dat onderling verband tussen uitspraken onder woorden. Eenmaal verwoord en door latere uitspraken bevestigd, ${ }^{\circ}$ kan van een jurisprudentiële rechtsregel worden gesproken.

Om de cohesie binnen het positief recht te vrijwaren en, in het bijzonder, kortsluiting met de staatsstructuur te vermijden, moet het toepassingsgebied van de jurisprudentiële rechtsregels nauwkeurig worden afgebakend.

Hun inhoud, zin en draagwijdte moeten niet enkel op wettelijke rechtsregels zijn geënt, maar mogen daarmee bovendien niet onverenigbaar zijn. Jurisprudentiële rechtsregels moeten rechtstreekse of onrechtstreekse ${ }^{4 \mathrm{I}}$ verbijzonderingen van wettelijke rechtsregels zijn, waarmee ze niet in botsing mogen komen.

Zou zich toch een dergelijke botsing voordoen, dan moet de jurisprudentiële rechtsregel aan het kortste einde trekken.

Binnen de grenzen van de toepassingsvoorwaarden en van de, door de wettelijke rechtsregel opgelegde gebiedende of verbiedende, gedragsregel is er ruimte zat voor talloze jurisprudentiële rechtsregels die de wettelijke toepassingsvoorwaarden dan wel het wettelijk ge- of verbod uitwerken.Artikel ${ }_{3} 382 \mathrm{BW}$ is daarvan een treffende illustratie. ${ }^{42}$

4I. Daarbij rijst vanzelfsprekend de vraag op grond van welk criterium (welke criteria) een jurisprudentiële rechtsregel eerder met één welbepaalde inhoud, dan met een andere wordt bedacht.

39 Zie o.m. P. Taelman, Het gezag van het rechterlijk gewijsde. Een begrippenstudie, Mechelen, Kluwer, 200I, $465 \mathrm{p}$.

40 Voornamelijk de bevestiging door de hoogste rechtscolleges is van tel.

4I Onrechtstreeks wanneer het gaat om jurisprudentiële rechtsregels die een eerdere jurisprudentiële rechtsregel verder uitwerken, wat zich vaak voordoet.

42 Zoals o.m. blijkt uit recente overzichten van rechtspraak, gewijd aan die wetsbepaling: B. Dubuisson, V. Callewaert, B. De Coninck en G. Gathem, La responsabilté civile, chronique de jurisprudence, 1996-2007, I, Le fait générateur et le lien causal, Brussel, Larcier, 2009, I074 p.; M. Van Quickenborne, Aansprakelijkheid uit onrechtmatige daad (2000-2007), I, Oorzakelijk verband, TPR 20Io, 283 e.v.; H. Vandenberghe, Aansprakelijkheid uit onrechtmatige daad (2000-2008), II, III en IV, TPR 20I0, I749 e.v. en TPR 20II, 349 e.v. 
Als antwoord op die vraag wordt meestal naar het beleid van de rechter of van de rechterlijke macht verwezen: inhoudelijk stelt dat antwoord evenwel weinig voor, vermits dat beleid inhoudelijk onbeschreven en dus ontoegankelijk blijft.

Voor de hand liggend is dat de keuzes of opties van de beoordelers worden bepaald door de, in hun ogen, gangbare maatschappelijke, onder meer politieke, sociale, morele, economische en/of juridische waardeoordelen, die zich tijdens het hiervoor bondig beschreven rechtsbedelingsproces manifesteren.

Even ondoorgrondelijk en complex als de waardeoordelen die aan de basis van de wettelijke rechtsregels liggen, zijn de daarbij aan het werk zijnde rechterlijke waardeoordelen een reden te meer om er stevig de hand aan te houden dat de jurisprudentiële rechtsregel zich binnen het kader van één of meerdere wettelijke rechtsregel(s) situeert en daarmee steeds en in alle opzichten verzoenbaar blijft. 43

De vaststelling dat de beoordelers die jurisprudentiële rechtsregels uitwerken, niet over de middelen beschikken die de wetgevers bij rechtsregelvorming kunnen inzetten, maakt die vereiste enkel dwingender.

Voortgaan op eigen inzichten, zonder dat de beoordeler de kwaliteit of de volledigheid van zijn/haar inzichten aan de controle van een derde kan onderwerpen dan wel controleerbaar kan maken, gaat met een toegenomen risico van vergissingen gepaard: averechtse effecten dan wel rechtsregelontwijkende gedragingen liggen daardoor in het verschiet.

\section{c) Voorlopig, complex besluit}

42. De complexiteit blijkt een wezenlijk en onvermijdelijk kenmerk van de wettelijke en jurisprudentiële rechtsregel te zijn. Zij neemt in het kader van de rechtsbedeling bovendien exponentieel toe.

Wanneer getrainde juristen reeds tot die bevinding komen, dan is nauwelijks te overzien hoe de man/vrouw in de straat, zonder vergelijkbare juridische kennis, het rechtsgebeuren moet vrezen of wantrouwen.

Complex en ondoorgrondelijk moet het rechtsgebeuren overkomen, zodat het gezegde dat elkeen wordt geacht de toepasselijke wet of rechtsregel te kennen, hem/ haar ofwel de angst om het hart doet slaan, dan wel elk vertrouwen in het rechtengedoe ontneemt. Daarmee wordt noch de samenleving, noch de openbare diensten van het recht en van de rechtsbedeling een dienst in de goede richting bewezen.

Veel accurater is de aanpak die erin bestaat de nadruk op de regulerende werking van het recht, alsmede op de conflictbeslechtende functie van de rechtsbedeling te leggen.

Maatschappelijk is het feit van de regulering en van de conflictbeslechting belangrijker dan de inhoud van de rechtsregel en van de uitspraak: de essentie van beide openbare diensten en hun maatschappelijke relevantie ligt besloten in een regelgeving waaraan ieder rechtssubject een boodschap heeft, en in de 
geschillenbeslechting wanneer zich tussen rechtssubjecten botsende opdrachten belangen voordoen.

Eenmaal die fundamentele opdrachten centraal staan kan worden toegelicht dat zowel de rechtsregel als de rechtsbedeling - gelet op hun onvermijdelijke complexiteit - zodanig is opgevat, gestructureerd en georganiseerd, dat - ondanks de menselijke onvolmaaktheid - aansluiting wordt gezocht met de in de samenleving gangbare, onder meer politieke, sociale, morele, economische en/of juridische opvattingen en bekommernissen, wanneer het erop aankomt de inhoud van de rechtsregel te bepalen. Daaraan is toe te voegen dat ook de beslechting van geschillen gebeurt op grond van de in de samenleving gangbare, onder meer politieke, sociale, morele, economische en juridische opvattingen en bekommernissen, toevertrouwd aan de beoordeler, waardoor een evenwichtige benadering van de conflicterende belangen mogelijk wordt.

Een beroep op leuzen (iedereen wordt geacht de toepasselijke rechtsregel te kennen; iura novit curia) die van zodra ze aan het zonlicht worden blootgesteld door de mand vallen, wordt daardoor overbodig.

43. De eerste onderzoeksvraag die naar de complexiteit van het rechtsgebeuren peilt, is derhalve om te buigen tot de vraag of er van de perceptie van toenemende complexiteit van het rechtsgebeuren iets overblijft, wanneer abstractie wordt gemaakt van de complexiteit, die ieder rechtsgebeuren (ont)siert.

Van Gerven en Lierman zijn, om juridisch-technische redenen, van mening daarop bevestigend te kunnen antwoorden. Zij verwijzen naar de toenemende meergelaagdheid waaronder het rechtsgebeuren gebukt gaat. ${ }^{44}$

Aan het onderzoek van de piramidale complexiteit is derhalve niet te ontkomen.

\subsubsection{Piramidale complexiteit}

\section{a) De hiërarchie der normen}

44. In het Belgische recht geldt sinds oudsher een hiërarchie der normen, wat met meergelaagdheid van het rechtsgebeuren gepaard gaat. ${ }^{45}$

Er wordt van uitgegaan dat de hiërarchisch hoger geplaatste rechtsregel op de lager geplaatste voorrang heeft, wanneer hun toepassingsvoorwaarden gelijktijdig vervuld zijn.

De opgebouwde hiërarchie is piramidaal omdat, zo wordt eveneens aangenomen, aan de top ervan minder rechtsregels dan aan de basis voorkomen.

44 W. Van Gerven en S. Lierman, Algemeen deel, Veertig jaar later, in Beginselen van Belgisch privaatrecht, I, Mechelen, Kluwer, 2010, 603 p.

45 M.b.t. die hiërarchie der normen: zie o.m. W. Van Gerven en S. Lierman, o.c., I5I-I72; I. Hachez, 'Les sources du droit: de la pyramide au réseau et vice versa', in Les sources du droit, IV, Limal, Anthemis, 2012, 55-100. 
De hiërarchie der normen is erop gericht de toepassing van de rechtsregels te 'vergemakkelijken' door een criterium aan te reiken, namelijk hun plaats in de hiërarchie, wanneer over de toepasselijke rechtsregel twijfel bestaat.

Om daarvan de vruchten te kunnen plukken, is een juist inzicht in de meergelaagdheid vereist. Dat inzicht is, in de regel, aan juridisch geschoolden voorbehouden.

Voor personen die juridische scholing missen, blijven de rechtsregels/normen even ondoorgrondelijk en complex, met of zonder hiërarchie.

45. Alvorens op de ontwikkeling in te gaan die de hiërarchie der normen kende, is bij het daarin voorkomende woord 'normen' stil te staan.

De hiërarchie omvat alle normen, ongeacht de formele bron waaraan zij hun bestaan danken.

De jurisprudentiële rechtsregels zijn aldus op het hiërarchisch niveau van de wetten te situeren, die hun grondslag vormen.

Wanneer de jurisprudentiële rechtsregel uit meerdere wetten (in de materiële betekenis) is afgeleid, zoals onder meer met een zogenoemd algemeen rechtsbeginsel het geval is, moet hij worden gesitueerd op het niveau van de hiërarchisch hoogst geplaatste wettelijke rechtsregel waaraan hij zijn bestaan ontleent.

De hiërarchie omvat ook de jurisprudentiële rechtsregels die op grond van een reeds eerder geformuleerde jurisprudentiële rechtsregel zijn uitgewerkt.

46. In die hiërarchie schakelen zich eveneens de gewoonte en de billijkheid in.

Daarbij is een onderscheid te maken al naargelang een wettelijke rechtsregel uitdrukkelijk naar de toepassing van de gewoonte, dan wel billijkheid verwijst. ${ }^{6}$

In dat geval zal de jurisprudentiële rechtsregel, die op de gewoonte of de billijkheid is gestoeld, zich op het hiërarchisch niveau van die wet situeren.

Zonder wettelijke grondslag is aan te nemen dat de jurisprudentiële rechtsregel, die op de gewoonte dan wel op de billijkheid wordt gesteund, aan alle andere normen ondergeschikt is.

Zulks verklaart overigens de wankele positie in het Belgische recht van jurisprudentiële verschijningsvormen van de zogenoemde objectieve goede trouw (redelijkheid en billijkheid), wanneer de wetgever er geen toepassing van heeft gemaakt.

De zogenoemde vertrouwens- of schijnleer, het zogenoemde verbod van rechtsmisbruik, enz. zijn op te vatten als spookrijders in de hiërarchie der normen

46 Voorbeelden op het vlak van de billijkheid zijn de artikelen II35 en I386bis van het Burgerlijk Wetboek. 
wanneer aan die jurisprudentiële 'rechtsregels' toch voorrang op rechtsregels wordt gegeven, die hun plaats in de hiërarchie op grond van wetgevende initiatieven kunnen verantwoorden.

47. De hiërarchie der normen biedt geen oplossing voor de conflicten tussen rechtsregels die zich op eenzelfde hiërarchisch niveau situeren.

Gelet op het groot aantal rechtsregels dat eenzelfde niveau bevolkt, doen dergelijke conflicten zich regelmatig voor.

Wanneer het conflict op eenzelfde niveau erin bestaat dat een wettelijke met een jurisprudentiële rechtsregel botst, ${ }^{47}$ komt aan de wettelijke rechtsregel voorrang toe. Die keuze is niet door de persoonlijke voorkeur van de verslaggevers ingegeven, maar is het onmiddellijke en rechtstreekse gevolg van de staatsstructuur, waarin de verordenende macht (ge- of verbod) niet aan de beoordelers (in het kader van de rechtsbedeling), maar wel aan de wetgevers (lato sensu) werd en wordt toegekend.

Jurisprudentiële rechtsregels horen derhalve buiten beschouwing te blijven wanneer zij aan een conflicterende wetgevende rechtsregel van hetzelfde niveau afbreuk doen.

48. Het conflict kan zich verder onderling voordoen tussen wettelijke dan wel jurisprudentiële rechtsregels die zich op eenzelfde hiërarchisch niveau situeren.

De oplossing is dan vooreerst in de aard van de met elkaar conflicterende rechtsregels te zoeken.

Zoals onder juristen bekend is, zijn de gebiedende/verbiedende rechtsregels van de wilsaanvullende rechtsregels te onderscheiden.

Tot de eerstgenoemde categorie behoren de rechtsregels die de openbare orde dan wel de goede zeden aanbelangen, alsmede de rechtsregels van dwingend of imperatief recht..$^{8}$

Komt een rechtsregel van wilsaanvullend recht met een gebiedende/verbiedende rechtsregel in botsing, dan weet de jurist - in beginsel - wat gedaan: de wilsaanvullende rechtsregel delft het onderspit in de mate dat hij met de ge- of verbiedende rechtsregel onverenigbaar is.

49. Ook tussen ge- of verbiedende rechtsregels die tot eenzelfde hiërarchisch niveau behoren, kunnen er zich conflicten voordoen.

Dwingende of imperatieve rechtsregels zijn handig als concept, maar zij zijn vanuit rechtstheoretisch oogpunt ten opzichte van de rechtsregels van openbare orde/ goede zeden moeilijk inpasbaar en te verantwoorden. ${ }^{49} \mathrm{Zij}$ lijken voornamelijk om

47 Wat andermaal interpretatie vergt.

48 Het gebod of verbod kan als dusdanig uit de wettekst volgen, dan wel daaruit door de bijkomende jurisprudentiële rechtsregels zijn afgeleid. Dat onderscheid is van belang wanneer is te bepalen of een wetmiskenning met een burgerlijke fout is te assimileren (zie T. Léonard, o.c., TBH 2013, 960-973).

49 P. Van Ommeslaghe, o.c., I, 338-348; P. Wéry, o.c., I, 303-307; P. Wéry, 'L'essor du droit impératief et ses rapports avec l'ordre public en matière contractuelle', in I. Samoy (ed.), Evolutie van de basis- 
pragmatische redenen te zijn geconcipieerd, namelijk om afwijkingen op rechtsregels die anders van openbare orde/goede zeden zouden zijn, te kunnen verantwoorden.

Niettemin van hun bestaan uitgaande dringt zich de vaststelling op dat de imperatieve of dwingende rechtsregel het onderspit moet delven, wanneer hij tegen een rechtsregel ingaat die de openbare orde dan wel de goede zeden aanbelangt, vermits laatstgenoemde rechtsregels geen afwijking dulden.

In theorie kan ook aan een conflict tussen rechtsregels van openbare orde enerzijds en rechtsregels met betrekking tot de goede zeden anderzijds worden gedacht.

Om die hypothese te kunnen doorgronden is het nodig dat de begrippen 'openbare orde' en 'goede zeden' van elkaar zijn te onderscheiden.

De verslaggevers zijn de mening toegedaan ${ }^{50}$ dat zulks niet mogelijk is: de goede zeden verwijzen naar de morele orde die voor een samenleving bepalend is. Zij vormen aldus een onderdeel van de openbare orde die naar de gangbare maatschappelijke onder meer politieke, sociale, morele, economische en/of juridische, enz. basisregels verwijst, waardoor een bepaalde samenleving op een bepaald tijdstip is georganiseerd..$^{\mathrm{I}}$

Daaruit volgt dat het overbodig is naar een voorrangsregel tussen openbare orde en goede zeden te zoeken.

50. De volgende stap bestaat erin de conflicten in overweging te nemen die zich tussen de rechtsregels kunnen voordoen die op eenzelfde hiërarchisch niveau huizen en bovendien van dezelfde aard zijn.

Technische voorrangsregels zijn beschikbaar om die conflicten aan te pakken.52

Van de rechtsregel van recentere makelij kan worden aangenomen dat hij beter aan de actuele samenleving dan de oudere rechtsregel is aangepast.

De bijzondere rechtsregel werd, in beginsel, ontwikkeld om (maatschappelijke) noden te lenigen die met een algemenere rechtsregel moeilijk of niet waren op te vangen.

Doorslaggevend kunnen die technische voorrangsregels evenwel niet worden genoemd.

beginselen van het contractenrecht, Antwerpen, Intersentia, 20IO, I2I-I42.

50 Opvatting die reeds ten tijde van de voorbereidende werken van de Code civil door Dhr. Fauré (toespraak van I5 maart I803) werd verdedigd (Locré, Législation civile, commerciale et criminelle, Brussel, Tarlier, I836, I, 319).

5I Zulks volgt o.m. uit de - voor het overige sibilijnse - omschrijving van de openbare orde door het Hof van Cassatie (o.m. Cass. 9 december 1948, Pas. 1948, I, 699); zie ook L. Cornelis, 'About public order and other vermin', in Finance and law, twins in trouble, te verschijnen bij Intersentia, Antwerpen, 20I4.

52 O.m. W. Van Gerven, Algemeen deel, 58. 
Zoals hierna wordt hernomen ${ }^{33}$ moet in eerste instantie worden onderzocht welke botsende maatschappelijke belangen via de conflicterende rechtsregels in de weegschaal liggen.

Ongeacht de aard van de rechtsregels moeten juristen ermee leren omgaan dat er inhoudelijke voorrangsregels tussen rechtsregels bestaan en moeten bestaan: een meer dan uitdagende en inspirerende vaststelling. Die inhoudelijke voorrangsregels zijn immers nog tot leven te brengen.

b) Tussenbeschotten die naar ontdubbelingen leiden

5I. De hiërarchie der normen heeft aldus sinds lang voor een ingewikkeld kluwen gezorgd, waarin het gemakkelijk verloren lopen was en is.

Die toestand moet dus buiten beschouwing worden gelaten wanneer naar toegenomen complexiteit van het rechtsgebeuren wordt gepeild.

Terecht benadrukken Van Gerven en Lierman ${ }^{54}$ dat de hiërarchie der normen in 2014 moeilijk of niet met die hiërarchie der normen, bijvoorbeeld in I830, vergelijkbaar is.

Ontwikkelingen die voornamelijk sinds een vijftigtal jaren op gang kwamen of zich hebben herhaald, hebben niet enkel de omvang maar ook de vorm en de structuur van de hiërarchie der normen gewijzigd.

Eerst als een piramide opgevat blijkt zij die - driedimensionele - vorm te zijn ontgroeid.

$\mathrm{Zij}$ lijkt thans meer op een cilinder met een buikje en vooral op de hoogste niveaus deden zich meerdere (stille) revoluties voor.

Initieel aan de Grondwet voorbehouden nestelden er zich, naargelang de desbetreffende publiekrechtelijke visie, op datzelfde niveau of, volgens sommigen, op een hoger niveau, tal van internationale dan wel supranationale (wettelijke en jurisprudentiële) rechtsregels.

52. Die internationale en supranationale rechtsregels (met horizontale, dan wel verticale rechtstreekse werking), en ongeacht het niveau waarop ze worden gesitueerd, hebben voorrang op alle rechtsregels van nationale oorsprong. Ten aanzien van grondwettelijke rechtsregels wordt het conflict-althans in beginsel-vermeden doordat de, op basis van de Grondwet aan internationale verdragen of instellingen toegekende, bevoegdheden nauwkeurig (moeten) zijn omschreven en er wordt aangenomen dat ze de Grondwet uitwerken en vervolledigen.

Bevoegdheidsafbakeningen gaan evenwel steeds met interpretaties gepaard, afgezien van de alom bekende verleiding om een paar stappen (of meer) op andermans terrein te zetten.

53 Zie hierna nr. 88.

54 W. Van Gerven en S. Lierman, o.c., 9-I2. 
De grenzen van bevoegdheidsdelegaties afbakenen is een lastige klus, zeker in de afwezigheid van een (onafhankelijke) supranationale overheid die over de verenigbaarheid met de bevoegdheidsdelegatie van de, daarop ogenschijnlijk gesteunde, wettelijke dan wel jurisprudentiële rechtsregels bindend kan beslissen.

Overheidsinstellingen die een onderdeel van de internationale of supranationale structuur zijn, zijn rechter en partij wanneer het over gebeurlijke bevoegdheidsoverschrijdingen gaat, waardoor hun onpartijdigheid en onafhankelijkheid vragen oproept.

Het belang van die vaststelling is niet te onderschatten, zeker niet in een economische unie waar andere belangen bovendrijven dan in een politieke of sociale unie het geval zou zijn.

53. Bevoegdheidsdelegaties, met de eraan verbonden moeilijkheden, kregen intussen zo goed als alle niveaus van de Belgische hiërarchie der normen in hun greep.

Meer en meer wetgevers kunnen, volgens het boekje, slechts binnen de hun toegewezen bevoegdheden rechtsregels tot stand brengen: die bevoegdheidsdelegaties, gesitueerd op eenzelfde hiërarchisch niveau, doen zich als tussenbeschotten voor, waardoor het 'jachtgebied' van elke wetgever wordt begrensd.

Existentiële regeldrift, de behoefte zich ten opzichte van andere wetgevers te laten gelden, zelfs wanneer is geweten dat de ingeroepen bevoegdheid voor betwisting vatbaar is, zorgen voor een steeds verder uitdijend wetgevend lappendeken, waarop steeds meer jurisprudentiële rechtsregels worden afgestemd.

Vanzelfsprekend werden er juridische mechanismen en instellingen in het leven geroepen, waardoor toezicht op gebeurlijke bevoegdheidsoverschrijdingen mogelijk is. Daardoor ontstaan nieuwe jurisprudentiële rechtsregels die ertoe strekken de bevoegdheidsdelegatie nauwkeuriger te begrenzen, maar die ook zelf voor betwisting kunnen zorgen.

Niet alle bevoegdheidsoverschrijdingen worden overigens (meteen) aangevochten: in afwachting van een gebeurlijke betwisting vertroebelen de over de schreef gaande rechtsregels de hiërarchie der normen.

54. De tussenbeschotten, gesitueerd op eenzelfde hiërarchisch niveau, veranderen de structuur van de hiërarchie. Zij leiden tot meerdere piramidale hiërarchieën, die tezamen de globale hiërarchie der normen vormen.

De ontdubbelingen van de hiërarchie der normen waartoe die tussenbeschotten leiden, zorgen onmiskenbaar voor een toenemende complexiteit van het rechtsgebeuren: er kunnen geen (goed getrainde) ogen genoeg zijn om de verschillende piramides en hun onderling verband in de gaten te houden. Bezwarend daarbij is dat, alle voorzorgsmaatregelen ten spijt, niet kan worden gegarandeerd dat de afbakening van de bevoegdheidsdelegatie door de ultieme beoordeler correct kan worden voorspeld. 55 
Die verhoogde moeilijkheidsgraad om de toepasselijke rechtsregel te bepalen, kan aan toegenomen meergelaagdheid worden toegerekend, maar het pijnpunt wordt nog nauwkeuriger omschreven wanneer de schijnwerpers op de tussenbeschotten worden gericht die tot de hoogste hiërarchische niveaus zijn doorgedrongen, alsmede door de afwezigheid van een afdoende anticipatieve of corrigerende controle op de verenigbaarheid van de daaropvolgende regulering met de bevoegdheidsdelegatie.

\subsubsection{De keizerlijke (uit)weg?}

\section{a) Aantrekkelijke subjectieve rechten}

55. Die overdonderende, globale hiërarchie der normen, waarin slechts met grote moeite een lijn is te trekken, ontmoedigt zelfs getrainde juristen.

Moeilijkheden vragen een oplossing of, als zulks niet meteen lukt of als te belastend wordt ervaren, om omzeild te worden. Juristen weerstaan daaraan niet: wanneer zij door de bomen het bos niet meer zien, zoeken ze een redding nabij. Zij schakelen op subjectieve rechten of, nog onbegrensder, op belangenafwegingen over.

Aan subjectieve rechten (en de, in een rechtsverhouding daartegenover staande verbintenissen) is niets verkeerd, zolang de, op de feiten toepasselijke rechtsregels de inhoud, de zin en de draagwijdte van de macht bepalen, die de schuldeiser onder de garantie van sanctie en dwang op de schuldenaar kan laten gelden..$^{6}$

De macht om van de schuldenaar een welbepaalde prestatie (iets geven, doen of niet doen) te eisen, kan de schuldeiser slechts aan de voorafgaande vaststelling ontlenen dat de toepassingsvoorwaarden van één of meer rechtsregels ten aanzien van de schuldenaar verenigd raakten, waardoor laatstgenoemde onder het in die rechtsregels vervatte ge- of verbod valt en daarom aan de schuldeiser de gevorderde prestatie verschuldigd is.

Subjectieve rechten hebben ten opzichte van de onderliggende rechtsregels een feitelijke toegevoegde waarde: zij zijn een punctuele, aan de feitelijke omstandigheden aangepaste, bijzondere en concrete synthese van één of meer rechtsregels.

Via subjectieve rechten transiteren de (toepasselijke) rechtsregels naar de feiten en vervolgens van de feiten terug naar die toepasselijke rechtsregels.

56. Populair om de rechtsregels naar de achtergrond te verdringen en aldus, meer dan eens, uit hun hengsels te lichten, is de 'uitbouw' van subjectieve rechten en, nog ondoorzichtelijker, van (beschermingswaardig geachte) belangen.

In de plaats van de (juridische) aandacht op de feiten en op de daarop toepasselijke rechtsregels te richten, wordt op basis van een prima facie onderzoek tot het bestaan van één of meer subjectieve rechten besloten.

56 T. Léonard, Conflits entre droits subjectifs, libertés et interest légitimes, Brussel, Larcier, 2005, 29-I05. 
In functie van de feitelijke omstandigheden en van een belangenafweging, waarover de beoordeler heer en meester is, worden de grenzen van de subjectieve rechten en de daaraan te verbinden gedragingen uitgetekend.

Zodoende wordt door de beoordeler bepaald welk gedrag van de schuldenaar kan worden geëist, respectievelijk van de schuldeiser kan worden getolereerd. Het beroep op subjectieve rechten is aldus een ander, handiger middel dan de (algemene, abstracte en duurzame) rechtsregel om het gedrag van de rechtssubjecten, via een a posteriori beoordeling, te reguleren.

De handigheid bestaat erin dat de beoordeler op zweet en tranen bespaart: hij/zij kan het spoor van de rechtsregels verlaten en met de subjectieve rechten een binnenweg nemen om tot de uitspraak te komen.

Een onvoorbereid toeschouwer zou kunnen vragen wat daarop is aan te merken.

Het antwoord luidt, kort en goed, 'onnoemelijk veel'.

57. De afbakening van het subjectief recht ${ }^{57}$ blijkt immers te kunnen gebeuren zonder dat wordt nagegaan of het daarmee bereikte resultaat al dan niet met de, op de in aanmerking genomen feiten, toepasselijke rechtsregels in overeenstemming dan wel verenigbaar is.

Er wordt integendeel voluit voor uitgekomen dat die binnenweg bestaat om zich aan de zogenaamd rigiditeit van de toepasselijke rechtsregels te onttrekken, wat als een rechterlijke correctie wordt aangeprezen..$^{8}$

Met het te bereiken resultaat voor ogen, wordt m.a.w. voluit toegegeven dat er in de op subjectieve rechten afgestemde rechtsbedeling van de, in beginsel, toepasselijke rechtsregels wordt afgeweken, omdat zij om - zelden of nooit toegelichte - redenen niet passend (?) worden geacht en derhalve, in een concreet en bijzonder geschil, via de omweg van het subjectief recht, correctie behoeven.

De in het duister blijvende motieven die tot de zogenoemd corrigerende gedragsregels ${ }^{59}$ leiden, zijn overigens een tweede steen des aanstoots.

In absolute termen bestaat er geen perfecte rechtsregel, zoals er evenmin een perfecte mens rondloopt. Over de verbetering van eender welke rechtsregel kan bodemloos worden gefilosofeerd, al kunnen daaruit constructieve en beredeneerde voorstellen tot aanpassing volgen.

57 Waartoe o.m. het jurisprudentieel uitgewerkte verbod van rechtsmisbruik strekt: pleegt rechtsmisbruik, de persoon die kennelijk de grenzen te buiten gaat van de uitoefening van een (subjectief) recht door een normaal redelijk persoon; L. Geudens, Het verbod op rechtsmisbruik in contracten, Brugge, die Keure, 20I4, I46 p. en T. Léonard, o.c., 757-832.

58 O.m. A. Lenaerts, Fraus omnia corrumpit in het privaatrecht, Brugge, die Keure, 2013, 37I-392.

59 De corrigerende gedragsregel is meestal bekend, maar de beweegredenen van de beoordeler die verklaren waarom hij/zij tot die welbepaalde correctie besloot, worden niet ontsloten. 
Die mogelijkheid van gedachtewisseling bestaat evenwel niet wanneer subjectieve rechten als sluipweg worden gebruikt om aan het juk van een of andere rechtsregel te ontsnappen.

De grenzen van het subjectief recht worden door de beoordeler 'à la carte' uitgestippeld op basis van feitelijke beoordelingen en belangenafwegingen die hoogstens kunnen worden vastgesteld, maar door de beoordeler zelden of nooit worden ontsloten.

De verenigbaarheid van die toestand met de basisbeginselen inzake vrijheid en gelijkheid wordt, op zijn minst, in het gedrang gebracht.

Vermits de onderliggende gedragsregel waarvan de beoordeler meteen een toepassing maakt onuitgesproken blijft, ontbreekt de garantie dat in dezelfde of zelfs gelijkaardige feitelijke omstandigheden eenzelfde gedrag van elke burger zal worden verwacht. Zulks gaat met een (aanzienlijk) risico van willekeur gepaard, die vrijheids- en gelijkheidsbeperkend is.

De rechtsregel biedt tegen dat alles bescherming door de algemene, abstracte en duurzame toepassingsvoorwaarden, die verenigd moeten zijn opdat via het (wettelijk of rechterlijk) ge- of verbod, één rechtssubject op een welbepaald gedrag van een ander rechtssubject aanspraak zou krijgen.

Door tot subjectieve rechten en hun draagwijdte te besluiten, zonder na te gaan of het kader van de abstracte, algemene en duurzame toepassingsvoorwaarden van de onderliggende rechtsregels wordt geëerbiedigd, groeit er een (niet te verantwoorden) kloof tussen die rechtsregels en de gedragsregels, die uit de subjectieve rechten worden gededuceerd en meteen op een procespartij worden toegepast.

58. Het is maar een kleine stap van de in het duister gehulde ondergrond van het subjectief recht, opgevat als een zogenoemde correctie op de rechtsregel, naar de persoon van de beoordeler.

Subjectieve rechten worden immers door de beoordeler gewikt en gewogen.

Op zijn/haar feitelijke beoordelingen en belangenafwegingen (die met elkaar zijn verknocht) komt het in de rechtsbedeling, gebaseerd op subjectieve rechten, aan. De rechtsregels worden daarbij tot een algemeen kader herleid, een voorwendsel om de beoordeler toe te laten, op basis van feitenbeoordeling en belangenafweging, tot de 'gepaste' subjectieve rechten te besluiten, daaruit gedragsregels af te leiden en meteen op een procespartij toe te passen.

Met de, als correctie op de rechtsregel uit de kast gehaalde, subjectieve rechten werd een stille revolutie ingezet die, er kan en mag niet worden aan voorbijgegaan, met een impliciete omwenteling van de politieke structuren en orde gepaard gaat.

Op de keper beschouwd wordt de rechtsregel (algemeen, abstract, duurzaam en eenzijdig bevel van een bevoegde overheid) onder de vorm van een subjectief recht, tot een bijzondere, concrete, punctuele gedragsregel omgedoopt en eventueel vervangen, die door de aan de slag zijnde beoordeler wordt uitgewerkt. 
De regulerende beslissingsmacht van de wetgevers wordt via rechtsbedeling ${ }^{60}$ door de feitenbeoordeler overgenomen, wanneer hij/zij het subjectief recht van de onderliggende rechtsregels loskoppelt, wat bovendien enkel marginaal door de hoogste rechtscolleges ${ }^{6 \mathrm{r}}$ kan worden gecontroleerd.

De gedragsregel op grond waarvan het geschil in de hypothese door de feitenbeoordelers wordt beslecht, wordt door zijn/haar feitelijke inschattingen en de belangenafwegingen gevormd. Hij/zij is daarvoor op zich/haarzelf aangewezen: ${ }^{62}$ zijn/haar wijsheid, opvoeding, ervaring, gemoedstoestand, vernuft, creativiteit, volgzaamheid, alertheid, nieuwsgierigheid, leergierigheid, energie, tegenslagen, scepticisme, ironie, visie, opvattingen, enz. staan in dat beslissingsproces centraler dan de rechtsregel.

De feitenbeoordelingen en belangenafwegingen die zich daarop, nog steeds in die hypothese, meteen enten, zijn een ongedefinieerde en overigens ondefinieerbare cocktail van gevoelens en rede, zelfs voor de beoordeler, ongeacht de aan zelfkennis bestede tijd.

\section{b) Belangenafwegingen: nog aantrekkelijker}

59. De weg die wordt gevolgd wanneer de rechtsbedeling op grond van corrigerende subjectieve rechten gebeurt, is reeds sterk subjectief en oncontroleerbaar.

Het wordt nog erger wanneer de door de beoordeler bepaalde en toegepaste gedragsregel louter op feitelijke belangenafweging is gebaseerd, vanzelfsprekend aan die beoordeler voorbehouden. ${ }^{63}$

Wanneer slechts de bij het geschil betrokken of opduikende belangen in aanmerking worden genomen om het 'gepaste' gedrag te bepalen, kunnen de rechtsregels nog meer uit de weg worden gegaan; er wordt zelfs op hun schaduw bespaard.

Belangen verwijzen naar materiële en morele voordelen die worden nagestreefd. Het vermijden van een materieel of moreel nadeel geldt evenzeer als belang.

De belangenafweging die naar een werkwijze verwijst zonder te bepalen in functie van welk criterium er wordt 'afgewogen', komt erop neer dat de beoordeler bepaalt wat, gelet op de met elkaar botsende belangen in een welbepaald geschil, al dan niet aan elke geschilvoerende partij 'hoort' toe te vallen en daarom van haar kan worden verwacht. In functie van die - a posteriori - (gedrags)beoordeling wordt het geschil beslecht.

Ten onrechte zou die belangenafweging met de verdelende rechtvaardigheid in verband worden gebracht.

60 P. Scholten, o.c., II9-I65.

6I De marginale controle (in de plaats van de volledige controle) bepleit een rechterlijke terughoudendheid in de beoordeling: in wezen een vrome, maar oncontroleerbare wens.

62 P. Scholten, o.c., 77-86 en I69-2I9.

63 T. Léonard, o.c., I74-288. 
6o. Indien rechtvaardigheid inhoudt dat wordt bepaald wat aan elkeen toekomt, dringt zich immers nochtans het besluit op dat zij niets gemeen heeft met de belangenafweging op grond waarvan een beoordeler, bij veronderstelling, individuele en concrete geschillen beslecht.

De rechtvaardigheid is gebaseerd op vooraf bepaalde, en dus kenbare, verdelende criteria, waarvan de toepassing het besluit rechtvaardigt dat er al dan niet rechtvaardig is gehandeld of een rechtvaardige toestand is bereikt. De daartoe gebruikte verdelende criteria zijn, per definitie, algemeen, abstract en duurzaam om de kenbaarheid ervan te vrijwaren en een consequente toepassing mogelijk te maken. Ze worden bepaald met het oog op de verdeling van middelen en lasten op groepsniveau. De individuele en concrete belangen van de partijen die de pech hebben met elkaar in een geschil verwikkeld te raken, komen in dat stuk niet voor.

Op zichzelf staande belangenafwegingen die in het kader van de rechtsbedeling opgang maken, beantwoorden niet aan die rechtvaardigheidsvoorwaarden: de criteria waarmee de belangenafweging gebeurt, zijn in dat kader vooreerst onbekend, zodat zij noch voor tegenspraak, noch voor onderzoek en controle vatbaar zijn. De belangenafweging wordt een 'soevereine' beslissing genoemd, omdat zij op individuele en concrete omstandigheden voortgaat, die als een feitelijke beoordeling worden gekwalificeerd (onder voorbehoud van een marginaal wettelijkheidstoezicht, dat, in wezen, op een belangenafwegingstoezicht neerkomt).

In werkelijkheid zijn niet de feiten maar wel de waardeoordelen van de beoordeler, in wisselwerking met de individuele en concrete, met elkaar botsende belangen van de partijen, doorslaggevend. Dat maakt meer dan een slok verschil.

Het heeft mogelijk, gelet op het kader waarin het zich voordoet, een schijn van rechtvaardigheid, maar is daarvan mijlenver verwijderd: het mag worden gezegd.

\subsubsection{Complex besluit}

6r. Het rechtsgebeuren, emanatie van de openbare diensten van het positief recht en van de rechtsbedeling, ontkomt niet aan het besluit dat het, per definitie, door grote complexiteit wordt gekenmerkt.

Die vaststelling geldt niet enkel vanuit het perspectief van de burger, maar ook uit dat van de jurist. Niet voor niets vergt zijn/haar vorming meerdere levensjaren. In het beste geval is het daarmee bereikte resultaat dat de gevormde jurist er zich rekenschap van geeft dat zijn/haar vorming een levenstaak wordt, wil hij/zij niet louter persoonlijke belangen nastreven.

Juridische kennis mag geen middel zijn om de intrinsieke complexiteit van het rechtsgebeuren toe te dekken.

Adagia zijn daarin sterk: de leuzen dat elkeen wordt geacht de toepasselijke rechtsregel te kennen dan wel dat de beoordeler het recht kent (iura novit curia), leiden naar valse zekerheden en zorgen voor frustratie wanneer uitkomt dat de werkelijkheid zich anders voordoet.

Eerlijkheid duurt het langst, ook in het rechtsgebeuren.

Ervoor opkomen dat recht en rechtsbedeling, zoals elke menselijke activiteit, met gissen en missen gepaard gaan, is geen schande. Het verschil tussen theorie en praktijk is trouwens niet aan het rechtsgebeuren voorbehouden. 
Waar het op aankomt, is dat het juridisch gissen en missen en de intrinsieke onzekerheid ervan (die op complexiteit wijst en ze versterkt) op de handhaving van de gangbare maatschappelijke, onder meer politieke, sociale, morele, economische en juridische opvattingen en bekommernissen gericht blijft. Daarom en onder die voorwaarde zijn recht en rechtsbedeling als openbare diensten in het leven geroepen.

62. De overweldigende complexiteit die het rechtsgebeuren doordesemt, is vooreerst aan te treffen in de totstandkoming zowel van de wettelijke ${ }^{64}$ als van de jurisprudentiële rechtsregel. ${ }^{65}$

Beleidsmakers en juristen hebben er een gewoonte van gemaakt om die complexiteit te minimaliseren, eerder dan bescheiden toe te geven dat zij niet beter kunnen, omdat complexiteit en onzekerheid nu eenmaal aan het rechtsgebeuren eigen zijn. Wat in grote mate subjectief, bijzonder en concreet is, wordt door hen onder de dekmantel van een objectief, algemeen en abstract rechtsgebeuren aan de samenleving voorgesteld.

Hooggespannen verwachtingen zijn daarvan het gevolg, waaraan dat rechtsgebeuren, om de hiervoor toegelichte redenen en alle inspanningen ten spijt, jammer genoeg niet kan beantwoorden.

63. Het rechtsgebeuren wordt namelijk niet gestuurd door de betrachting om de waarheid of de rechtvaardigheid te laten zegevieren, maar wel om in het algemeen te benaarstigen dat de samenleving binnen een welbepaald, georganiseerd kader (politiek, sociaal, moreel, economisch) is gereguleerd en dat daarin opduikende geschillen, ter vrijwaring van dat kader, worden beslecht.

Uiteindelijk komt het met het rechtsgebeuren meer op de regelgeving en op de geschillenbeslechting dan op de inhoud van de rechtsregel of van de uitspraak aan.

Daarmee wordt niet gezegd dat aan de totstandkoming (de procedure) en aan de inhoud van de rechtsregel of van de uitspraak geen belang toekomt. De te volgen procedure en de inhoud van de rechtsregel of van de uitspraak bepalen immers de kwaliteit zowel van de samenleving, als van dat rechtsgebeuren: het belang daarvan kan niet voldoende worden benadrukt.

Toch staat daarbij steeds centraal dat procedure en inhoud zo belangwekkend zijn, omdat zij er, in eerste instantie, toe strekken de samenleving te reguleren en daarin opduikende conflicten niet te laten ontsporen, maar integendeel tijdig te neutraliseren.

De wereld wordt dan ook op zijn kop gezet wanneer wordt gedacht dat of wordt gehandeld alsof de (bijzondere, concrete, punctuele) inhoud van een (gedrags)regel of van een uitspraak de essentie van het rechtsgebeuren zou zijn.

64 Zie nrs. I9-25.

65 Zie nrs. 26-4I. 
Het rechtsgebeuren vindt zijn verantwoording op samenlevingsniveau, als instrument om de duurzaamheid van die samenleving te garanderen. Die betrachting, die geenszins aanpassing, remediëring en verbetering van het rechtsgebeuren uitsluit, staat centraal en vergt zowel regulering als geschillenbeslechting. Beide activiteiten impliceren, zonder de minste twijfel, optimale procedures en inhoud, maar de inspiratie daartoe is niet in subjectieve rechten of belangenafwegingen te vinden, wel in de gangbare maatschappelijke opvattingen en bekommernissen die, in een welbepaalde samenleving, aan de basis van haar politieke, sociale, morele, economische en juridische ordening liggen.

64. De bevattelijkheid van het rechtsgebeuren neemt sterk toe door, zonder dubbelzinnigheid, te benadrukken dat het rechtsgebeuren in mensenhanden ligt. De menselijke perfectie is meer dan relatief: bescheidenheid kan geen kwaad en maakt het mogelijk te erkennen dat rechtsregels al bij al gebrekkig voorbereid worden. Dezelfde bescheidenheid is ook inzake rechtsbedeling op haar plaats.

Het menselijk vermogen kan, inzake regelgeving en geschillenbeslechting, gewoonweg niet beter, maar zulks mag niet verhinderen dat er, met vallen en opstaan, naar rechtsregels en rechtsbedeling wordt gestreefd, die tot de gestructureerde organisatie, handhaving en financiering van de samenleving bijdragen, in overeenstemming met de maatschappelijk gangbare, onder meer politieke, sociale, morele, economische en juridische opvattingen en bekommernissen, die door het rechtsgebeuren worden geïmplementeerd.

Rozengeur en maneschijn zijn aan het rechtsgebeuren niet besteed: het is beter de tering naar de nering te zetten en daarbij paard en man te (be)noemen.

Wie met artificiële middelen naar erkenning of krediet hengelt, ontmoet vroeg of laat de - onverbiddelijke - man met de hamer. Het rechtsgebeuren bevindt zich, weliswaar ten onrechte, sinds lang in die toestand. Van maatschappelijke erkenning en van maatschappelijk krediet kan het rechtsgebeuren slechts dromen.

Voor een belangrijk deel hebben de wetgevers, de beoordelers en de juristen dit te danken aan, door hen in het leven geroepen, misleidende verwachtingen, waarop ze - getuigend van misplaatste standvastigheid - niet willen terugkomen.

65. In de plaats van de dubbelzinnigheid met betrekking tot de, nochtans niet te ontkennen, complexiteit op de spits te drijven, is een lans te breken voor een andere benadering van het rechtsgebeuren, gebaseerd op zijn maatschappelijke waarde en op, in toom te houden menselijke tekorten (waaraan ook juristen niet ontsnappen).

In afwachting daarvan hebben Van Gerven en Lierman het bij het rechte eind, wanneer zij de toenemende complexiteit met de 'meergelaagdheid' van het rechtsgebeuren associëren. ${ }^{66}$ 
Die exponentieel toegenomen complexiteit is voornamelijk toe te rekenen aan de tussenbeschotten die zich omwille van bevoegdheidsdelegaties of van bevoegdheidsopdelingen tot op de hoogste niveaus van de hiërarchie der normen hebben voorgedaan. Door die tussenbeschotten ontstaan er in wezen meerdere piramides (of dikbuikige cilinders) die zich naast elkaar bevinden en vaak op elkaar inhaken, omdat de bevoegdheden niet steeds voldoende nauwkeurig zijn omschreven en daardoor een bron van gewilde/ongewilde incidenten worden. ${ }^{67}$

Bijkomende piramides (of dikbuikige cilinders) ontstaan wanneer die hiërarchie niet enkel op basis van rechtsregels, maar ook louter op grond van corrigerende subjectieve rechten of, nog ondoorzichtelijker, van beschermingswaardig geachte belangen die op gedragsregels uitlopen, wordt geconcipieerd. ${ }^{68}$

Het rechtsgebeuren wordt daardoor een wespennest: door de samenvlechting van die verschillende en, in essentie, met elkaar onverenigbare piramiden of cilinders van normen, kunnen behendige rechtssubjecten, om hun belangen te optimaliseren, op hetzelfde moment alles en het omgekeerde daarvan nastreven en, mogelijk, bekomen.

Vermits de eerste onderzoeksvraag ${ }^{69}$ met een bevestigend antwoord wordt afgesloten, moet worden bepaald waaraan die vastgestelde, toegenomen complexiteit is toe te rekenen.

\section{I.2 Symptomen van vergiftiging}

\subsubsection{Eigenbelang meet zich met collectief belang}

66. Juristen zouden voorwaar de enigen zijn die, geconfronteerd met de toegenomen complexiteit van het rechtsgebeuren, de diagnose tot een toegenomen meergelaagdheid zouden beperken en, voor het overige, 'node' aan de beleidsmakers zouden overlaten om het tij, eventueel, te keren..$^{\circ}$

Zij doen er beter aan te erkennen dat zij de rechtsregels en de daaraan ontleende gedragsregels in ruime mate zelf bepalen.

Een geneesheer die tot een diagnose komt maar nalaat zich over de daarop aansluitende medicatie uit te spreken, krijgt het lastig. Waarom zou het voor een jurist anders zijn?

Het volstaat in andere menswetenschappen een kijkje te nemen om vast te stellen dat politicologen, sociologen, (moraal)filosofen, antropologen, economisten,

67 Zie nrs. 44-54.

68 Zie nrs. 55-60.

69 De eerste onderzoeksvraag peilt naar een gebeurlijke toenemende complexiteit van het rechtsgebeuren.

70 W. Van Gerven en S. Lierman (o.c., 48I-499) gaan verder dan de vaststelling, maar de diagnose is slechts gevolgd door - voorzichtig - geformuleerde bekommernissen, grotendeels van juridische aard. 
psychologen, historici, enz. de afstandelijke en hoofse benadering van de jurist niet genegen zijn..$^{\text {I }}$

Zij streven ernaar om met hun diagnoses de techniciteit van hun vakgebied te overstijgen en zich op samenlevingsniveau te situeren. Zij zoeken, gemotiveerd, naar remedies om (al dan niet vermeende) problemen op te lossen.

67. Het is noch de plaats, noch het tijdstip om op die verzamelde kennis en analyses in te gaan.

De grote lijnen daarvan zijn trouwens welbekend: de toegenomen complexiteit van het maatschappelijk gebeuren houdt alle geesten bezig.

Slechts ogenschijnlijk of gemakkelijkheidshalve is die toenemende maatschappelijke complexiteit door industriële, technische en/of technologische ontwikkelingen te verklaren.

Die ongetwijfeld diepgaande ontwikkelingen zijn in de huidige Westerse samenleving immers eerder zelf verschijningsvormen van een veel fundamenteler omwenteling in het gedachtegoed met betrekking tot de tussen de samenleving en het dikke-ik ${ }^{72}$ bestaande verhouding.

De samenleving dankt haar bestaan en voortbestaan aan de wens van de groepsleden om van de bescherming en de voordelen van de samenleving te genieten, in het besef dat zij die bescherming en voordelen, individueel, niet op eigen kracht kunnen evenaren.

Dat geldt ook voor de maatschappelijk sterksten, ${ }^{73}$ ook de elite genoemd. ${ }^{74}$

De van de samenleving verwachte bescherming en voordelen vergen structuren, organisatie, handhaving en financiering, die de groepsleden tot stand brengen en vervolgens ondergaan.

De structuren, organisatie, handhaving en financiering van de van de samenleving verwachte bescherming en voordelen houden noodzakelijk in dat de groepsleden water bij de wijn moeten doen en beperkingen moeten aanvaarden (zo niet opgelegd krijgen), die bij ontstentenis van samenleving hun doen en laten niet zouden bezwaren.

7I Een indrukwekkend en allesomvattend overzicht, weliswaar op de Noord-Amerikaanse samenleving afgestemd, is te lezen in Al Gore, The future, WH Allen, 2013, $55^{8} \mathrm{p}$.

72 Naar een omschrijving gebruikt door H. Kunneman, Voorbij het dikke-ik. Bouwstenen voor een kritisch humanisme, I, Amsterdam, SWP, 2009, 287 p.

73 In de hedendaagse Westerse samenleving worden de maatschappelijk sterksten vnl. in functie van hun vermogenstoestand omschreven, aldus o.m. T. Pikketty, Le capital au XXIème siècle, Paris, Seuil, 20I3, 970 p. die verwijst naar de Io\% meest vermogenden; M Sandel, What money can't buy. The moral limits of markets, Allen Lane, 20I2, 244 p. die spreekt van 'the affluent'. Op andere tijdstippen en/of plaatsen kan vanzelfsprekend een ander criterium bepalend zijn. Overigens steunen het vermogen en zijn toename zelf op andere criteria die evenzeer bepalend zijn (afstamming, hogere scholing, enz.).

74 O.m. F. Garçon, Enquête sur la formation des élites, Mernil-sur-Estrée, Perrin, 20II, 430 p. 
68. Bestaan en voortbestaan van de samenleving leidt aldus naar een spanningsveld met de, wellicht aan de door de evolutieleer benadrukte, drift ${ }^{75}$ van de groepsleden om, altijd en overal, naar eigen inzicht en belang te kunnen handelen.

Naarmate de door de samenleving verstrekte bescherming en voordelen een vast onderdeel van eenieders landschap zijn geworden, laait de haat-liefdeverhouding tussen de (onpersoonlijke ${ }^{76}$ ) samenleving en het dikke-ik op, waarop - in het bijzonder - de maatschappelijk sterksten behendig weten in te spelen.

Het spanningsveld tussen de zelfbeschikking die de groepsleden, terecht, nastreven en de samenleving die door middel van haar structuren, organisatie, handhaving en financiering de zelfbeschikking van de groepsleden tegelijk bevordert en beperkt, is een oud zeer, zoals uit de oudste geschriften en de geschiedenis sindsdien blijkt.

Het is manifest een explosief goedje: wanneer de verhouding uit balans geraakt, worden correcties onvermijdelijk die de bestaande samenleving, waarover onvrede bestaat, aantast, zo niet opblaast. Zoals door recente conflicten wordt bevestigd (de Arabische 'lente', Oekraïne, enz.) gebeuren die (fundamentele) aanpassingen zelden vreedzaam en offeren zij integendeel enkele generaties op, alvorens een nieuw evenwicht kan worden gevonden.

69. Zelfs zonder dramatische omwenteling is de perceptie van de verhouding tussen het collectief belang (de samenleving) en het eigenbelang (het dikke-ik) een perpetuum mobile. Het daarop betrekking hebbende gedachtegoed wordt, ononderbroken, in de ene of de andere richting aangescherpt. Het zijn die voortkabbelende wijzigingen waarop weinig of geen acht wordt geslagen, omdat ze aan de gang zijn en dus tot het dagdagelijkse decor behoren, die, onder omstandigheden, het plotse besluit kunnen uitlokken dat de verhouding onhoudbaar uit balans is geraakt.

70. De troeven van de hedendaagse Westerse samenleving hoeven geen uitvoerige toelichting: van haar wordt verwacht dat zij haar leden bescherming tegen indringers van buitenaf en tegen andere burgers met 'kwade' bedoelingen ${ }^{77}$ biedt.

Van haar wordt eveneens verwacht dat zij (preventief en curatief) voor de gezondheidszorg van haar leden instaat en voor doorgedreven onderwijs zorgt.

Interne en externe veiligheid zijn steeds essentiële en hoofdbekommernissen geweest..$^{8}$ Doorgedreven gezondheidszorg en onderwijs maakten pas in de twintigste eeuw een steile opgang, na de ontgoochelingen die door twee wereldoorlogen, en tussendoor een financieel economische crisis, werden veroorzaakt.

C. de Duve, Genetics of the original sin, New Haven, Yale, 20Io, 223 p.

Zo ervaart het dikke-ik de samenleving, wat hem/haar toelaat er zich van te dissociëren.

Die kwade bedoeling bestaat erin aan een ander lid opzettelijk schade te berokkenen, dan wel om eventuele schade, als gevolg van opzettelijk gedrag, erbij te nemen (zie o.m. A. Lenaerts, o.c., 316-323).

78 Zie o.m. D. Graeber, Debt. The first 5000 years, New York, Melvillehouse, 20II, 534 p. 
Wie het in de Westerse samenleving zonder die essentiële, op samenlevingsniveau verstrekte (openbare) diensten (vrede, veiligheid, gezondheid en/of onderwijs) moet waarmaken, is weinig meer dan een vogel voor de kat.

Meedogenloos worden de groepsleden die kortstondig of gedurende langere tijd die essentiële openbare diensten moeten missen, naar de marge van de samenleving verwezen, alvorens helemaal uit de boot te vallen.

Zelfs de maatschappelijk sterksten hebben die openbare diensten nodig. Privémilities, private gezondheidszorg en privaat onderwijs bestaan weliswaar, zodat zij die behoeften, althans ogenschijnlijk, zonder de tussenkomst van de samenleving zouden kunnen opvangen.

Evenwel zijn privémilities, private gezondheidszorg en privaat onderwijs slechts door hen te vertrouwen wanneer zij, naar personeel en in te zetten middelen, maatschappelijk zijn omkaderd.

De autonomie van de maatschappelijk sterksten reikt dus mogelijks verder dan die van andere groepsleden, maar ook zij blijven, rechtstreeks en onrechtstreeks, voor hun essentiële behoeften op de samenleving aangewezen.

7 I. De nadelen van de hedendaagse Westerse samenleving worden door de groepsleden echter minder en minder geduld. Om tot een vreedzame samenleving met georganiseerde gezondheidszorg en georganiseerd onderwijs te komen, moeten er gebiedende/verbiedende regels worden opgelegd en nageleefd, enerzijds, en moeten er structuren worden opgezet, georganiseerd, gehandhaafd en gefinancierd met middelen, die aan de groepsleden (of sommigen van hen) worden onttrokken, anderzijds.

Rechtstreeks en onrechtstreeks wordt daardoor de zelfbeschikking ${ }^{79}$ ingekort, dan wel beknot.

Naarmate het besef van die beperkingen toeneemt en/of wordt uitvergroot, neemt de onvrede daarover toe.

Het dikke-ik haalt dan, onweerstaanbaar, de bovenhand: er - al te snel - van uitgaande dat de samenleving door zijn/haar bijdragen wordt gestructureerd, georganiseerd, gefinancierd en gehandhaafd, meent het dikke-ik dat zij hoogstens een instrument mag zijn om de eigen levenswandel te vergemakkelijken.

Het dikke-ik wil niet enkel zo min mogelijk last van de samenleving, maar meent tevens dat zij op dieet moet om dikke-ikken over maximale middelen te laten beschikken.

79 De individuele vrijheid is het instrument om tot zelfbeschikking te komen. Door naar zelfbeschikking te verwijzen, wordt de relativiteit van het menselijk bestaan benadrukt, een - wezenlijk - aspect dat met de excessieve ophemeling van de individuele vrijheid in een dode hoek komt te zitten (zie o.m. T.F. Ruiz, The terror of history. On the uncertainties of life in western civilization, Princeton, P.U.P., 20II, 178 p.). 
Het volstaat ooit in enig groepsverband actief te zijn geweest ${ }^{80}$ om te weten dat het uitgangspunt van dit paradigma geen steek houdt: de groep en zijn realisaties zijn meer dan de optelsom van de bijdragen van de leden. Het dikke-ik maakt zich aan overschatting of manipulatie schuldig door voor te houden dat de samenleving hem/ haar dankbaarheid zou zijn verschuldigd: groepsleden, zelfs de dikste-ikken, zijn steeds substitueerbaar, terwijl de grondslagen van de - bestaande - samenleving dat niet zijn.

Voor de samenleving, zijnde al haar groepsleden, zijn de door haar structuren, organisatie, handhaving en financiering gegarandeerde essentiële openbare diensten ${ }^{8 \mathrm{r}}$ de ultieme finaliteit, waartegen de persoonlijke verzuchtingen van zelfs het dikste-ik niet (kunnen) opwegen.

De zelfbeschikking, met reden dierbaar aan elkeen van ons, ent zich op dat vooraf bestaande samenlevingskader.

Het paradigma van de zelfbeschikking is structureel van het samenlevingskader afhankelijk: het ontleent daaraan zijn inhoud, zin en draagwijdte.

Het collectief (of algemeen) belang en het eigen belang zijn van een verschillende orde van grootte waardoor zich - in theorie - geen botsingen of conflicten zouden mogen voordoen. Artikel 6 van het Burgerlijk Wetboek drukt de idee wonderwel uit. $^{82}$

Wanneer dergelijke botsingen of conflicten toch worden geduld, wijst zulks op belangeninversie. Eigenbelang hijst zich op het niveau van het collectief belang en meet zich ermee.

\subsubsection{Een geschiedenis die zich herhaalt}

72. Met de Franse revolutie is een ontwikkeling op gang gekomen die na de zogenoemde Belle Epoque door twee wereldoorlogen tijdelijk en brutaal tot stilstand is gebracht, doch vanaf de jaren I965-I970 de verloren gegane tijd zeer snel heeft weten te recupereren.

Kenmerkend voor die, overigens aan elkeen vertrouwd in de oren klinkende, ontwikkeling is de aan eenieder, principieel, toegezegde en de door elkeen opgeëiste persoonlijke vrijheid, ${ }^{8}$ waardoor de zelfbeschikking over de levensloop wordt bepaald.

8o Wat een gezins-, een beroeps-, dan wel vrijetijdsverband kan zijn.

8I Het zijn immers die openbare diensten die voor de structuur en de organisatie van de samenleving zorgen. De handhaving en de financiering ervan strekken er vervolgens toe die samenlevingsstructuur en -werking te vrijwaren en te bestendigen.

82 Artikel 6 BW: 'Aan de wetten die de openbare orde en de goede zeden betreffen, kan door bijzondere overeenkomsten geen afbreuk worden gedaan.'

83 M.b.t. de aan de individuele vrijheid toegekende maatschappelijke betekenis: P. Verhaeghe, Identiteit, Amsterdam, De Bezige Bij, 20I2, 27 I p.; R.D. Putman, Bowling alone, NY, Simon \& Schuster, 2000, 54I p.; C. Audard, Qu'est-ce que le libéralisme? Ethique, politique, société, Paris, Gallimard, 2009, $843 \mathrm{p}$. 
Sinds de Franse revolutie werd in amper één eeuw duidelijk gemaakt dat de individuele vrijheid niet enkel vele verschijningsvormen heeft en dus elastisch is te noemen, maar ook de bron van toenemende maatschappelijke ongelijkheden is.

Haar elasticiteit dankt de individuele vrijheid (de zelfbeschikking) aan de vaststelling dat de erdoor geboden mogelijkheden van de (persoonlijke en/of materiële) middelen afhankelijk zijn, waarover de titularis in concreto beschikt.

Om het met een boutade te zeggen: een hongerlijder is even vrij als een stervoetballer, maar hun beleving van de individuele vrijheid ligt ver uit elkaar.

Bovendien hadden de maatschappelijk sterksten snel door dat een, via een paradigma, gesacraliseerde individuele vrijheid op eerder ongeziene resultaten uitzicht gaf. Het volstond daartoe op de individuele vrijheid van anderen in te spelen, zodat zij de indruk zouden krijgen 'vrij' te beslissen, wat de maatschappelijk sterksten in wezen van hen gedaan wensten te krijgen.

Onder meer de overstap van de agrarische naar een industriële samenleving en de opkomst van de consumptiemaatschappij zijn daarvan een illustratie; het bleef daartoe niet beperkt.

In amper een vijftigtal jaren (I860-I9I4) werd daardoor de maatschappelijke ongelijkheid tussen de elite (ongeveer 10\%) en de rest van de bevolking tot ongekende proporties uitgediept, temeer algemene gezondheidszorg, algemeen onderwijs en sociale zekerheid op dat moment, hoogstens, in de kinderschoenen stonden.

De elite (Io tot $15 \%$ van de bevolking) legde de hand op het overgrote deel van de nationale rijkdom (ongeveer 80 tot $90 \%$ daarvan), ${ }^{84}$ in een periode zonder middenklasse.

Toen reeds ging individuele vrijheid (en zelfbeschikking) voor velen met een bittere nasmaak gepaard.

73. Na de herverdelingen en de eendrachtige heropbouw, die door twee opeenvolgende wereldoorlogen en de tussentijdse financieel-economische crisis in het Westen noodzakelijk waren gemaakt, heeft de lokroep van het dikke-ik, overgestimuleerd door de maatschappelijk sterksten die de verloren gegane glorie en hegemonie zo snel mogelijk wilden heroveren, zich vanaf 1965 -I970 van het maatschappelijk gebeuren meester gemaakt.

Vanaf toen werd meer en meer op het kompas van de individuele vrijheid gevaren, in het bijzonder gerechtvaardigd door de overtuiging dat de vrijheid van de maatschappelijk sterksten de ganse samenleving ten goede zou komen. De rode loper werd dan ook voor hen uitgerold.

Een tijdlang slaagden de maatschappelijk sterksten er trouwens in de schijn hoog te houden door aan de samenleving betere resultaten voor te leggen, dan de

84 T. Piketty, o.c, 538-550. 
resultaten die de overheid met een meer georganiseerde en dus vrijheidsbeperkende samenleving bleek te kunnen boeken.

Intussen is duidelijk geworden dat die, in eerste instantie, hoopgevende resultaten voornamelijk door een (eenmalige) inhaalbeweging en een bevolkingstoename zijn te verklaren, waarvoor de maatschappelijk sterksten zich geen pluim op de hoed kunnen steken. ${ }^{85}$

Even duidelijk is geworden dat de individuele vrijheid naar een concentratie van rijkdom en macht leidt, omdat de maatschappelijk sterksten van geen ophouden weten, steeds meer rijkdom en macht nastreven en de concentratie van rijkdom en macht sneller en sneller willen laten plaatsvinden. Op korte termijn denkend en aannemend dat hun doel de middelen heiligt, worden allerhande zeepbellen geblazen om hun doelstellingen te halen ${ }^{86}$ en worden scenario's uitgewerkt om hetzij tijdig de benen te kunnen nemen, hetzij de verliezen/lasten bij anderen (liefst de samenleving) te alloceren. ${ }^{87}$

74. Vermits rijkdom en macht onder meer in het hedendaagse Westen met vermogen en vermogenstoename wordt geassocieerd, hebben de maatschappelijk sterksten zich op het ruilverkeer toegelegd, dat zij op uiteenlopende manieren naar hun hand proberen te zetten.

Ruilverkeer impliceert immers een ruilverhouding tussen de waarde van de 'geruilde' goederen en/of diensten.

Wie erin slaagt om de ruilverhouding stelselmatig in zijn/haar voordeel om te buigen, zet eenrichtingsvermogenstransferten op die op vermogensaccumulatie uitdraaien.

De opgang van het ruilverkeer is door het door de overheid gecontroleerde muntwezen mogelijk gemaakt. Het muntwezen aan de maatschappelijk sterksten toevertrouwen is - zo leert de geschiedenis overduidelijk ${ }^{88}$ - geen optie. Eerder vroeg dan laat leidt zulks naar excessieve valsspelerij, waardoor niet enkel het muntwezen, maar ook het ruilverkeer zelf (thans economie genoemd) op apegapen komt te liggen. ${ }^{89}$

Het ruilverkeer gaat dus met vermogenstransferten gepaard, wanneer de ruilverhouding ongelijk is bepaald. In die hypothese ontvangt een partij meer dan zij geeft en maakt zij winst.

85 T. Piketty, o.c, I26-I79.

86 T. Piketty, o.c., 270-278.

87 De IJslandse monetair-financiële crisis is een voorbeeld van snel de benen nemen; de financieeleconomische crisis sinds 2007 illustreert hoe de financiële sector (vennootschappen en hun aandeelhouders) gigantische verliezen wist te collectiviseren (zie inzake de bancaire activiteit A. Admati en M. Hellwig, The bankers' new clothes, Princeton, P.U.P., 2012, 398 p.).

88 D. Graeber (Debt. The first 5000 years, NY, Melleville, 20II) toont dit overtuigend aan.

89 Het recente wedervaren van de zgn. 'bitcoin' is daarvan een bijkomende illustratie. 
Bij veralgemening, herhaling en steeds groter wordende ongelijke ruilverhouding wordt de vermogensaccumulatie geoptimaliseerd.

Tegenover die vermogensaccumulatie staat een correlatieve verarming van de wederpartijen in de ruilverhouding. Hoe groter hun aantal, hoe minder zij de effecten van de ongelijke ruilverhouding - in beginsel ${ }^{90}-$ zullen voelen.

Vele kleintjes maken een groot euvel: wanneer steeds dezelfde wederpartijen in de elkaar opeenvolgende ruilverhoudingen - die zij als uitdrukkingen van hun individuele vrijheid benaderen - aan het kortste einde trekken en dus meer geven dan zij krijgen, doet er zich snel verarming van die wederpartijen voor.

Recent sociaal-economisch onderzoek ${ }^{9 \mathrm{r}}$ heeft aangetoond dat de vermogensongelijkheden die de Belle Epoque ontsierden, zich heden ten dage ook in het zogenaamd rijke Westen opnieuw voordoen en, gelet op de economische hefbomen die aan het werk zijn, nog dramatischer vormen aannemen en verder zullen blijven aannemen..$^{92}$

\subsubsection{Spiegeltje aan de wand, wie is de sterkste in dit land?}

75. Het geeft op zijn minst stof tot nadenken dat de vermogensongelijkheid die het einde van de negentiende eeuw kenmerkte, op ultraliberaal gedachtegoed, zonder sociale vangnetten, was gesteund, terwijl de actuele vermogensongelijkheid, ondanks de intussen door de samenleving uitgebouwde sociale vangnetten, toeneemt. ${ }^{93}$

Beide perioden hebben met elkaar gemeen dat het eigenbelang langzaam maar zeker boven het collectief belang is beginnen tronen, wat door een gewijzigde perceptie van het tussen die belangen bestaande onderlinge verband mogelijk is gemaakt.

Het grote verschil bestaat erin dat de maatschappelijk sterksten in de tweede helft van de negentiende eeuw de overheid rechtstreeks controleerden. ${ }^{94} \mathrm{Zij}$ konden hun eigenbelang derhalve moeiteloos op al het overige laten voorgaan en voor elke toegeving hard onderhandelen.

Op dit moment is zulks, gelukkig, niet langer het geval, maar de ontwikkeling die vanaf ${ }_{19} 65$ is ingezet en in de jaren 1990 , voorlopig, met de zogenoemde mondialisering en/of globalisering van economische en financiële activiteiten werd bezegeld, moet worden geanalyseerd als een sluipweg om, in een sterk gewijzigd maatschappelijk kader, toch tot eenzelfde resultaat (of erger) te komen.

90 Bij bedrog of gekwalificeerde benadeling werkt de verarming veel sneller door.

9I Dat is de verdienste van T. Piketty en de groep van onderzoekers rondom hem die de data bij elkaar brachten verwerkt in Le capital au XXIème siècle (Paris, Seuil, 20I3).

92 Meer bepaald de, op data gebaseerde vaststelling dat het rendement op kapitaal het percentage van de jaarlijkse groei van het BNP overtreft, enerzijds, en dat het rendement op kapitaal toeneemt in functie van de orde van grootte ervan, anderzijds; zie hierna nr. Iog.

93 Afgezien van het werk van T. Piketty, ook J. Stiglitz, The price of equality, London, Penguin Books, 2013, 523 p.; Changing inequalities in rich countries, Analytical and comparative perspectives (ed. W. Solverda e.a.), Oxford, UP, 20I4, 4II p.; Changing inequalities and societal impacts in rich countries. Thirty countries experiences (ed B. Nolan e.a.), Oxford, UP, 20I4, 743 p.

94 Via het cijnsrecht beschikten zij alleen over het kies- en verkiesbaarheidsrecht. 
De maatschappelijk sterksten, bij voorkeur actief in internationaal gestructureerde 'corporations' (vennootschapsgroepen, met opdeling zowel van de handelsactiviteiten als van de private vermogens) hebben eerst onrechtstreekse controle op de nationale overheden nagestreefd, met tewerkstelling en belastinginkomsten als hefbomen. Met die toestand wordt door hen evenwel minder en minder vrede genomen, zoals uit exotische delokaliseringen blijkt om het rendement op hun investeringen de hoogte in te jagen.

Die tendens maakt de voornamelijk nationale overheden - die (moeten?) laten begaan - steeds kwetsbaarder: het leidt ertoe dat de nationale overheden het dubieus eigenbelang van de maatschappelijk sterksten voor lief moeten nemen en dat het, op de één of andere wijze, zelfs een onderdeel van het socio-economische overheidsbeleid wordt.

76. Aan de basis van die ontwikkelingen ligt de inversie in de perceptie van het belang dat aan de samenleving, respectievelijk aan het dikke-ik toekomt.

Op ingenieuze en meergelaagde wijze zijn de promotoren van de individuele vrijheid erin geslaagd om bij een overgrote Westerse meerderheid de rotsvaste overtuiging in te hameren dat het eigenbelang met het collectief belang kan wedijveren en het zelfs overklast.

Consument, producent, investeerder, werknemer, werkgever en rentenier vallen elkaar in de armen wanneer het erop aankomt 'hun' individuele vrijheid tegen elke inmenging vanwege de overheid of anderszins van buitenaf te beschermen. De gemeenschappelijke vijand is weliswaar de overheidsinmenging, maar ook in verhouding met andere groepsleden staat elkeen op zijn/haar eigenbelang, gediend door de individuele vrijheid.

De 'hype' daarrond is dermate groot dat die meerderheid erbij neemt dat de individuele vrijheid, waarover de maatschappelijk sterksten beschikken, disproportioneel groot is, vergeleken met de vrijheidsbeoefening die voor de - grote - meerderheid weggelegd is.

Er wordt hun eveneens, zonder veel nadenken, vergeven dat zij die disproportionele mogelijkheden in eigenbelang aanwenden om het collectief belang onder vuur en bij de neus te nemen, omdat elkeen ook zijn/haar eigenbelang wil kunnen nastreven.

77. Alles bij elkaar genomen is het voor het dikke-ik erg gemakkelijk om van de hoge toren te blazen wanneer de samenleving, dankzij inspanningen waarvoor meerdere generaties hebben ingestaan, alle essentiële voorzieningen (vrede, veiligheid, gezondheidszorg, doorgedreven onderwijs, enz.) ter harte neemt.

Van die hoge toren een ivoren toren makend zet het dikke-ik er zich voor in om de indruk, het paradigma, te cultiveren dat hij/zij in de samenleving allesbepalend is en moet zijn.

Hoge, zelfs ivoren, torens zonder grondvesten is geen lang bestaan gegund.

De hoge, ivoren torens van het dikke-ik zingen het uit omdat zij hun grondvesten in de structuren, de organisatie, de handhaving en de financiering van de openbare diensten vinden, die de samenleving in het collectief belang ter beschikking van de groepsleden stelt. 
De inhoud, zin en draagwijdte van die openbare diensten zijn de verantwoordelijkheid van de overheid (niet van de maatschappelijk sterksten). De gangbare maatschappelijke, onder meer politieke, sociale, morele, economische, juridische, enz. opvattingen en bekommernissen worden door de overheid in die openbare diensten geïntegreerd. Die taak komt haar en haar alleen toe.

Kortom, de perceptie en, mogelijk, illusie van - onbegrensde - individuele vrijheid als ultiem levensdoel, mist grondslag. Zelfs de levensloop van Mevr. Ayn Rand bevestigt dat. ${ }^{95}$ Zonder de structuren, organisatie, handhaving en financiering van de samenleving via openbare diensten, zou het dikke-ik daarvoor zelf moeten instaan: de 'samenleving' zou er daardoor onvergelijkbaar anders uitzien en van het dikke-ik, bezig met de zorg (vrede, veiligheid, gezondheid en onderwijs) voor zichzelf en de zijnen, zou nog bitter weinig te horen of te vrezen zijn.

78. De perceptie dat het eigenbelang waardevoller dan het collectief belang wordt geacht, is aan bevraging toe.

Vermits de hoge, ivoren toren van het dikke-ik zijn bestaan aan (maatschappelijke) grondvesten dankt, moet hij/zij een toontje lager leren zingen.

De fundamenten, die ook de toren van het dikste-ik overeind houden, moeten voor elkeen dezelfde te zijn. Daarom moet worden vermeden dat de maatschappelijk sterksten ermee kunnen doorgaan hun torens steeds verder op te hogen en de grondvesten ervan te verstevigen met gebruik van middelen, die zij aan de fundamenten van de samenleving en dus van anderen onttrekken.

Vermogenstransferten van de meerderheid naar de minderheid en/of inkorting van de herverdeling die de vermogensconcentratie in handen van de minderheid tegenwerkt, kunnen als kiespijn worden gemist, zeker wanneer zij, op termijn of bij veralgemening, de grondvesten van de samenleving in het gedrang brengen.

\subsubsection{Belangeninversie in het rechtsgebeuren?}

79. Vermits het rechtsgebeuren zich op het maatschappelijk gebeuren ent, moet het vanuit het perspectief van dat maatschappelijk gebeuren worden geanalyseerd.

Daarvan uitgaande rijst de vraag of het rechtsgebeuren zich al dan niet door de hiervoor beschreven belangenversie heeft laten beïnvloeden, dan wel overmeesteren.

Veel onderzoek is niet nodig om vast te stellen dat de juristen zich gedurende de laatste vijf decennia voornamelijk hebben ingezet en laten inzetten om elkeens dikke$\mathrm{ik}^{96}$ zo veel mogelijk in bescherming te nemen, zowel op het vlak van de regelgeving als van de rechtsbedeling.

95 Ondanks haar literair succes, was Mevr. Ayn Rand in de jaren I970 van een leefloon en een ziekte-uitkering afhankelijk.

96 Waarbij overigens is te benadrukken dat de (financiële) middelen die inzetbaar moeten zijn om op het rechtsgebeuren een beroep te doen en om, via dat medium, voor (eigen) individuele vrijheid en eigenbelang op te komen, tot gevolg hadden dat voornamelijk de maatschappelijk sterksten de juristen onder de arm namen en aldus het rechtsgebeuren stuurden. 
a Greep op regelgeving

8o. De - overigens uiteenlopende - piramides, gebaseerd enerzijds op internationale normen die individuele vrijheden en rechten centraal stellen, en anderzijds op subjectieve rechten en op belangenafwegingen, getuigen daarvan. ${ }^{97}$

De hiërarchie van supranationale normen, die in het kader van de - economische - Unie werd uitgewerkt, is in hoofdzaak op vrij verkeer en op vrije mededinging gesteund. Die technieken om het ruilverkeer te bevorderen, voornamelijk in het eigenbelang van de maatschappelijk sterksten, gaan uit van de hoop of, erger, het geloof dat daardoor tegelijk het collectief belang zou worden gediend. Op het einde van de negentiende eeuw bleek evenwel reeds overduidelijk dat die hoop, dat geloof elke feitelijke grondslag mist..$^{8}$

Afgezien daarvan hebben de regelgevers in de tweede helft van de twintigste eeuw al te lang geloofd dat zij hun taken en opdrachten risicoloos via deregulering of herregulering, dan wel privatisering, aan de maatschappelijk sterksten konden delegeren.

Zij hebben aldus niet alleen de kat bij de melk gezet (en de politieke orde onder hoogspanning geplaatst), ${ }^{99}$ maar hebben daardoor tegelijk de greep op het maatschappelijk gebeuren, in het bijzonder op het vlak van de economie en financiën, verloren. Zij controleren niet langer de maatschappelijk sterksten, die in die sectoren actief zijn: zij missen vaak zelfs de kennis en de inzichten die daartoe nodig zijn, omdat zij er eerder de ogen van hebben afgewend. Wie klappen vraagt, krijgt die ook.

\section{b Greep op rechtsbedeling}

8I. De rechtsbedeling volgde eenzelfde trend.

Zowel de jurisprudentiële rechtsregels als de punctuele, bijzondere en concrete gedragsregels die in de rechtsbedeling welig tieren, worden daar, per definitie, in functie van met elkaar conflicterende eigenbelangen geconcipieerd.

Feitenbeoordelers zijn kinderen van hun tijd: opgeleid in de ban van de persoonlijke vrijheid, die voor de behartiging van eigenbelang wordt ingezet, blijken zij daarmee meer voeling dan met samenlevingsbelangen te hebben.

$\mathrm{Zij}$ wegen bij voorkeur de, door de individuele vrijheid gestuurde, eigenbelangen af die in het kader van een geschil met elkaar botsen.

De wettelijke rechtsregels blijven uiteraard algemeen richtinggevend, maar hun toepassingsvoorwaarden worden zo ruim mogelijk opgevat, om de beoordeler meer en meer beoordelings- en beslissingsruimte te gunnen. Zogenoemde jurisprudentiële correctiemechanismen zijn daarvan het logische gevolg.

97 Zie hiervoor de nrs. 55-6o.

98 Wat het einde van de twintigste en, in het bijzonder, de aanvang van de eenentwintigste eeuw (met de financieel economische crisis van 2007) heeft bevestigd.

99 In het bijzonder door de onrechtstreekse democratie te laten verwateren ( $\mathrm{T}$. Todorov, Les ennemis intimes de la démocratie, Paris, Laffont, 20I2, 260 p.; L. Huyse, De democratie voorbij, Leuven, Van Halewijck, 20I2, 2II p. 
Het juridische speelveld wordt aldus door punctuele belangenafwegingen gekenmerkt, waarover de beoordeler wikt en beschikt.

Soms gaat de uitdeinende interpretatie en/of correctie van de wettelijke rechtsregels zover dat zij worden geneutraliseerd en daardoor, in het kader van een geschil, voor ongeschreven worden gehouden.

Het klinkt hard; een paar voorbeelden uit het verbintenissenrecht zorgen voor 'passende' illustratie.

82. De aan het verbod van rechtsmisbruik jurisprudentieel toegekende corrigerende functie leidt ertoe dat aan de titularis van een subjectief recht de mogelijkheid wordt ontzegd om zich, geheel of deels, op dat recht te beroepen. ${ }^{\text {10o }}$

Vermits het subjectief recht verwijst naar de macht om van een ander rechtssubject te eisen dat een welbepaalde prestatie ${ }^{\text {Ior }}$ wordt geleverd, omdat het zich, gelet op de feitelijke omstandigheden, in de toepassingsvoorwaarden van één of meer rechtsregels bevindt die dat rechtssubject ertoe verplichten aldus te handelen, gaat de neutralisering van het subjectief recht noodzakelijk met een evenredige neutralisering van de, daaraan onderliggende rechtsregels gepaard.

Juristen proberen die vaststelling af te zwakken door kurkdroog te verklaren dat het verbod van rechtsmisbruik zelf een rechtsregel en dan nog wel een algemeen rechtsbeginsel is. ${ }^{102}$

Daarmee is mogelijks de schijn gered; onverklaard blijft evenwel hoe is te verantwoorden dat een correctieve, jurisprudentiële rechtsregel ${ }^{103}$ de toepassing van wettelijke rechtsregels, die steeds aan de basis van subjectieve rechten liggen, kan uitschakelen. De wetgevers en hun werking worden daarbij kennelijk niet ernstig genomen.

Ongetwijfeld kan en zal de met het verbod van rechtsmisbruik nagestreefde correctie goed bedoeld zijn.Vaak wordt zij bedacht om aan de zwakkere bijkomende bescherming tegen een sterkere te bieden.

Die correctie, die noodzakelijk anecdotisch en punctueel blijft vermits zij zich tot één geschil beperkt en naar bestaan, inhoud en draagwijdte van de inzichten van de feitenbeoordeler afhankelijk is, stelt maatschappelijk weinig voor.

Ioo Zie Cass. 8 februari 200I, RW 200I-2002, 778-779 met noot A. Van Oevelen; L. Geudens, o.c., I04II2.

IOI Die een geven, een doen of een onthouden tot voorwerp kan hebben: steeds wordt - impliciet - naar een daarmee overeenstemmend gedrag verwezen.

I02 S. Stijns, Verbintenissenrecht, I, Brugge, die Keure, 2005, 52; A. Lenaerts, 0.c., 375-377. Het Hof van Cassatie rekent het verbod van rechtsmisbruik tot de zgn. algemene rechtsbeginselen (o.m. Cass. 6 januari 20II, TBBR 20I2, 388).

I03 Zie hiervoor nrs. 56-58. 
Indien de zwakkere bescherming tegen de maatschappelijk sterkere behoeft, moet die bescherming algemeen, abstract en duurzaam worden verstrekt. Zij mag niet afhankelijk zijn van een (in te stellen) procedure en van de (goedbedoelde) inzichten van de feitenbeoordeler.

Het komt aan de wetgever toe die bescherming te bieden en indien hij nalaat zulks te doen, moet hij daarover worden aangesproken en verantwoording afleggen.

Juridisch geschoolde stemmen kunnen daarbij zwaar wegen.

De vaststelling dat de wetgevers, actueel, al te veel van de maatschappelijk sterksten afhankelijk (willen) zijn, is onvoldoende reden om de basisbeginselen van het democratisch staatsmodel af te vallen. Zulks speelt slechts in de kaarten van het kortetermijndenken.

Die vaststelling moet er integendeel toe leiden dat de democratisch georganiseerde samenleving van haar wetgevers eist dat deze steeds het collectief belang op elk eigenbelang laten voorgaan en het beschermingsniveau daarop afstemmen.

83. Een ander voorbeeld is in de jurisprudentieel gestuurde toenadering van het contractueel en het buitencontractueel aansprakelijkheidsrecht aan te treffen.

In het Burgerlijk Wetboek werden beide aansprakelijkheidsregimes, onder meer op het vlak van de vergoedbare schade en de causaliteit, van elkaar onderscheiden. ${ }^{\text {I04 }}$ Het toepassingsgebied van de contractuele aansprakelijkheid was daardoor beperkter dan de actieradius van het buitencontractuele aansprakelijkheidsrecht.

Zonder daar veel woorden aan vuil te maken werd ditverschil in de tweede helft van de twintigste eeuw jurisprudentieel dichtgereden: beide aansprakelijkheidsvormen hebben thans, op weinige uitzonderingen na, hetzelfde toepassingsgebied. ${ }^{105}$

84. Het laatste, en wellicht meest verregaande, voorbeeld is aan artikel 6 BW ontleend.

Sinds een zeventigtal jaren bekennen de, zelfs de meest vooraanstaande, Belgische juristen in koor hun onmacht, zo niet onvermogen om aan het in die wetsbepalingen opduikend begrippenpaar 'openbare orde' en 'goede zeden' een werkbare inhoud te geven. Dat begrippenpaar zou hun verzamelde krachten ver te boven gaan. ${ }^{\text {106 }}$

Juristen van alle slag hebben evenwel al voor veel hetere vuren gestaan: ze werken zich met grote vanzelfsprekendheid uit de meest netelige, juridische situaties.

Dat dit met het begrippenpaar 'openbare orde' en 'goede zeden' eeuwenlang niet wil lukken, wekt de indruk dat zij erop uit zijn de speelruimte te vrijwaren, die zij zouden kwijtspelen wanneer een sluitende omschrijving voorhanden zou zijn.

Aan het begrippenpaar een algemene, sluitende omschrijving ontzeggen, maakt artikel 6 BW en andere rechtsregels die dezelfde concepten gebruiken, monddood.

I04 Zie de artikelen II49, II50 en II5I BW.

I05 Zie L. Cornelis, 'Verkeerd verbonden', in V. Sagaert en D. Lambrecht (eds.), Actuele ontwikkelingen inzake verbintenissenrecht, Antwerpen, Intersentia, 2009, 272-29I.

ıo6 O.m. P. Van Ommeslaghe, o.c., I, 338; P. Wéry, o.c., I, 299. 
Het alternatief bestaat er immers in dat er slechts punctuele toepassingen uit de bus komen, waaraan, in één adem, wordt toegevoegd dat die toepassingen relatief zijn, omdat de samenleving voor verandering vatbaar is. ${ }^{107}$

\section{c Stand van zaken}

85. Deze voorbeelden betreffen geen details in het verbintenissenrecht, maar bepalen integendeel de structuur van die rechtstak.

Zij doorprikken het idyllische plaatje dat de beoordeler zich steeds aan de wettelijke rechtsregels zou weten te houden.

Het kan geen kwaad erop te wijzen dat een democratisch gestructureerde en georganiseerde samenleving een andere benadering van de beoordelers mag verwachten en dat de moeite die de beoordelers blijkbaar ondervinden om binnen de krijtlijnen van de wettelijke rechtsregels te blijven, in zich draagt dat zij zich van het door de wetgevers omschreven collectief belang afwenden.

Wat komt er in de plaats?

Jurisprudentiële rechtsregels, op de maat (van eigenbelang) gesneden subjectieve rechten en belangenafwegingen die de beoordeler in de beroepsbeoefening ongetwijfeld meer vrijheid geven: het dictaat van de (voornamelijk wettelijke) rechtsregel wordt ontlopen.

Voor de beoordeler blijkt het comfortabeler en voor zijn/haar zelfbeeld bevredigender om naar eigen inzichten te kunnen oordelen.

Weinig verbeeldingskracht is nodig om daarin de echo van de individuele vrijheid in het kader van de rechtsbedeling te herkennen: een specifieke vorm van belangeninversie.

86. Allemaal goed en wel: hoe gaan de beoordelers om met de, door hen aan henzelf toegekende, toenemende invloed op de rechtsbedeling?

Beoordelers beschikken niet over de middelen die wetgevers kunnen inschakelen om hun wetgevende initiatieven te kaderen en op de maat van de samenleving te snijden.

Mogelijks troosten zij zich met de idee dat ze die niet nodig hebben, omdat hun beoordeling slechts een micro- en geen macro-economisch effect heeft. Het geschil betreft ogenschijnlijk enkel een paar rechtssubjecten, niet de samenleving als dusdanig.

Die benadering miskent echter de precedentwaarde van de beoordeling, evenals de gedragsaanpassingen (ten goede of ten kwade) waartoe uitspraken aanleiding kunnen geven.

Nog zorgwekkender is dat de beoordeler, zelfs wanneer hij/zij over (afdoende) middelen zou beschikken om de invloed en draagwijdte van zijn/haar uitspraak, op

I07 O.m. P. Van Ommeslaghe, o.c., I, 345-35I; P. Wéry, o.c., I, 30I-302. 
termijn en bij herhaling, op de samenleving te bepalen, enkel bij zichzelf te rade kan gaan.

Van de beoordeler wordt 'wijsheid' verwacht. ${ }^{108}$ Waar haalt hij/zij de mosterd daartoe? Om in vrede met zichzelf te kunnen leven, zal de beoordeler de eigen opvattingen/zienswijzen volgen, die in ruime mate zijn bepaald door zijn/haar sociale achtergrond en door de beroepsgroep waartoe hij/zij behoort.

Door zijn/haar opleiding en maatschappelijke status behoort de boordeler tot de maatschappelijk sterksten, wiens taal hij/zij spreekt en wiens gedachtegoed hij/zij het beste kent en begrijpt.

De tijd dat overheidsinstellingen, bij een geschil betrokken, op ingebakken sympathie van de beoordelers konden rekenen, is sinds lang vervlogen.

Beoordelers worden scherp, kritisch, zelfs cynisch wanneer het overheidsoptreden ter beoordeling wordt voorgelegd: in regulatoire geschillen is dit schering en inslag. De individuele vrijheid krijgt een beschermende hand boven het hoofd gehouden.

De toegenomen vrijheid die de beoordelers bij de geschillenbeslechting opeisen, drijft hen niet enkel in de armen van het door de maatschappelijk sterksten gevolgde en ondersteunde gedachtegoed, zij leidt tevens tot verbrokkeling van de rechtspraak, zoals hiervoor werd beschreven. ${ }^{\text {109 }}$

\section{Oogt het plaatje fraai? Geeft het aanleiding tot juridische fierheid?}

Het eigenbelang, verpaktals individuele vrijheid, heeft de overheden klemgereden.

Doordat het individueel belang wordt gepercipieerd als belangrijker, minstens even belangrijk dan het collectief belang, wordt in de kaarten van de maatschappelijk sterksten gespeeld die, economisch en financieel, van dat paradigma optimaal gebruik kunnen maken.

Ze boeken er op alle fronten, inclusief op het vlak van de openbare diensten 'recht' en 'rechtsbedeling', successen mee.

Hun geaccumuleerde financieel-economische macht overtreft de macht die de overheden kunnen mobiliseren, mede doordat zij zich daaraan hebben weten te onttrekken. ${ }^{\text {iro }}$

Wie daaraan nog kan twijfelen, moet met de financieel-economische crisis die de wereld sinds 2007 teistert, zijn/haar les wel hebben geleerd.

Het zijn niet de brokkenmakers, maar wel de overheden (en dus de samenlevingen) die op de blaren zijn gaan zitten. De precedentwaarde daarvan is, zonder meer, huiveringwekkend.

Io8 De procespartijen kunnen zich overigens naar de wijsheid van de rechter gedragen, wat een principiële betwisting van het standpunt van de tegenpartij in houdt.

Iog Zie hiervoor nrs. 23-24 en 29.

IIO Door hun activiteiten te verleggen, dan wel door boekhoudkundige technieken die zgn. 'toelaten' om de resulaten van hun activiteiten naar fiscale en andere paradijzen te delocaliseren (zie hierna nrs. IIO-III). 
De regelgevers liggen in de lappenmand: wanneer het er echt op aankomt, m.a.w. wanneer het collectief belang met het eigenbelang van de maatschappelijk sterksten botst (of zelfs zou kunnen botsen), is de uitkomst, in de regel, bekend, hoe goed de overheden ook hun best doen om, met de hulp van de maatschappelijk sterksten, het gezicht te redden.

De rechtsbedeling biedt geen alternatief: niet alleen beschikken de maatschappelijk sterksten over de meeste middelen om hun kansen op dat strijdtoneel zo goed mogelijk te benutten, zij weten bovendien dat de rechtsbedeling, om de hiervoor toegelichte redenen, sterk anekdotisch verloopt. In functie van de persoon(lijkheid) van de beoordeler is alles en het tegendeel steeds en overal mogelijk. Afschrikken doet zulks hen niet; het leidt hen integendeel naar beredeneerde processtrategieën, waarvan de geschillenbeslechting niet langer, steeds, de prioriteit of de finaliteit is.

88. De discussie over de vraag welk belang voorrang heeft, is geenszins als zijnde theoretisch naar een vergeethoek te verwijzen. Het is integendeel bepalend voor de levensloop van de actuele en toekomstige generaties dat daarover klare wijn wordt geschonken.

Indien wordt doorgedraafd op de perceptie van de voorrang van het eigenbelang, staat niet alleen in de sterren geschreven dat de politieke structuren en organisatie steeds verder van het democratisch model zullen komen te liggen, ${ }^{\mathrm{III}}$ maar ook dat de concentratie van rijkdom en macht in steeds minder handen tot onhoudbare sociale spanningen en te verwachten explosies van geweld zullen leiden. ${ }^{\mathrm{II} 2, \mathrm{II} 3}$

De onder meer politieke, sociale, morele, economische, psychologische, enz. analyses die daarop met aandrang wijzen, zijn sinds lang beschikbaar. ${ }^{\mathrm{II}}$

Uiteraard is er niets of weinig nieuws onder de zon: zoals de maatschappelijk sterksten, die hun eigenbelang en individuele vrijheid met tabak of polluerende activiteiten nastreven, jarenlang met de ingekochte hulp van de zogenaamd 'beste' specialisten ${ }^{115}$ hebben bestreden dat er een verband tussen tabak en longkanker, dan wel tussen verontreiniging en opwarming zou bestaan, zo roepen die maatschappelijke sterksten ook thans alle hens aan dek om te betwisten dat er zich samenlevingsbedreigende ongelijkheden voordoen, die met het (verdergaande) verval van de democratie gepaard gaan.

Juristen, ook wanneer ze de complexiteit van het rechtsgebeuren betreuren, hebben de neiging de zijlijn te verkiezen en anderen te laten betijen, wanneer er zich maatschappelijke moeilijkheden voordoen.

III Al Gore, 0.c., I04-I33; T. Todorov, 0.c., 7-20, L. Huysse, o.c., I6-54.

II2 Zowel de Belle Epoque als de 'Arabische lente' zijn daarvan pijnlijke illustraties.

II3 Het geweld kan meerdere richtingen uit: onderdrukking door de maatschappelijk sterksten, uitschakeling van de maatschappelijk sterksten, buitenlandse oorlogen om binnenlandse problemen onder controle te houden, enz.

II4 Zie o.m. de hiervoor geciteerde werken van R. Wilkinson en K. Pickett, J. Stiglitz, Al Gore, T. Todorov, L. Huysse, T. Piketty.

II5 Die zich daartoe leenden, van hun individuele vrijheid eigenbelang gebruikmakend (zie N. Oreskes en E. Conway, Les marchands de doute, 20I0, 523 p.). 
Is de tijd niet aangebroken om die voorzichtigheid, die niet langer aan de zich voordoende situatie is aangepast, ter discussie te stellen?

Politieke, sociale, morele, economische, enz. analyses, hoe briljant en beklijvend ook, missen tanden die kunnen bijten om de zaken aan te pakken en/of te corrigeren. Juristen beschikken over de technieken van regelgeving en rechtsbedeling die, via sanctie en dwang, afdwingbaar zijn.

'Noblesse oblige': de organisatie, de handhaving en de financiering van de samenleving zijn hun, in ruime mate, toevertrouwd. De andere richting uitkijken dient mogelijk juridisch eigenbelang maar is, in de gegeven omstandigheden, geen te verdedigen optie.

In alle takken van het publiek en het privaat recht is dringend fundamenteel onderzoek nodig om te bepalen waar de belangeninversie zich heeft voorgedaan en hoe daaraan kan worden verholpen.

Geen rechtstak kan aan die oefening ontsnappen. De inversie heeft in elke rechtstak lelijk huisgehouden door het eigenbelang te laten betijen, zonder de impact op de samenleving, op termijn en bij veralgemening, (voldoende) in aanmerking te nemen.

De daaruit volgende bevindingen moet de juridische wereld onder de neus van de wetgevers blijven wrijven. Als zij niet thuis zouden geven, moeten juridische rechtsregels, op grond van het begrippenpaar openbare orde/goede zeden dat onder meer in artikel $6 \mathrm{BW}$ opduikt, soelaas brengen.

\section{I.3 Kentering op komst?}

89. De toenemende complexiteit van het rechtsgebeuren is derhalve het gevolg van de toenemende complexiteit van het maatschappelijke gebeuren, waarin zich de onverstoorbaar uitdijende belangeninversie voordoet.

Door het eigenbelang (de facto, het eigenbelang van de maatschappelijk sterksten) op het collectieve belang te laten voorgaan, nemen de ongelijkheden ongekende proporties aan, die op meer dan gespannen voet met democratisch uitgebouwde politieke en sociale (samenlevings)structuren staan.

Ervan uitgaande dat de belangeninversie van een verkeerd paradigma uitgaat, komt de derde onderzoeksvraag aan bod: kan het privaat recht ertoe bijdragen de toegenomen complexiteit van het maatschappelijk en het rechtsgebeuren te temperen en, eventueel, terug te dringen?

Op papier lijdt het antwoord geen twijfel: de middelen daartoe zijn in het rechtsgebeuren beschikbaar. Ze vergen evenwel de wil om ermee aan de slag te gaan en daardoor het collectieve belang op eender welk eigenbelang, te laten voorgaan. Zulks kan en moet nochtans gebeuren, zonder ervoor te moeten vrezen dat de individuele vrijheid, vector van eigenbelang en van zelfbeschikking, excessief in het gedrang zou komen, dan wel zou verdwijnen. 


\subsubsection{Eerherstel voor het gebiedend/verbiedend recht}

90. In het algemeen moeten 'privatisten' opnieuw durven (en willen) erkennen, dat hun activiteiten de samenleving ten goede moeten komen en dat private (eigen) belangen daaraan steeds ondergeschikt zijn.

Opnieuw... omdat die benadering, reeds in I804, de grondslag van het artikel 6 BW vormde. ${ }^{\text {II6 }}$

Eerder dan de gebiedende/verbiedende rechtsregels als te slopen hindernissen op te vatten, moet hun maatschappelijke relevantie door de juristen in ere worden hersteld.

Met de - al te goedkope - bewering dat het begrippenpaar 'openbare orde' en 'goede zeden' voor geen precieze en/of werkbare omschrijving vatbaar zou zijn, moet komaf worden gemaakt.

Er moet trouwens niet lang over de, aan dit begrippenpaar toe te kennen inhoud, zin en draagwijdte worden nagedacht om te beseffen dat zij geen juridische inhoud, maar wel een maatschappelijke betekenis behoeven.

Om uit te zoeken waarover het gaat, moet de jurist zich de inspanning getroosten om over de grenzen van de juridische techniek te kijken en zich met de gangbare maatschappelijke, onder meer politieke, sociale, morele, economische, juridische, enz. opvattingen en bekommernissen in te laten.

Geen kleine opdracht weliswaar, maar er is niet in te zien waarom juristen niet zouden aankunnen wat politicologen, sociologen, filosofen, historici, antropologen, economisten, historici, statistici, psychologen, enz. reeds jarenlang doen: de vinger aan de maatschappelijke pols houden.

Als excuus tot verdere afzijdigheid inroepen dat juristen daarmee geen ervaring hebben, slaat een mal figuur. Juristen weten maar al te goed hoe het verhaal eindigt wanneer de aangesprokene zich op eigen tekortkomingen beroept om zijn/haar aansprakelijkheid tegen te spreken of te milderen.

Alles aan de opdracht is, naargelang de benadering, loodzwaar of spannend en uitdagend.

Per domein (politiek, sociaal, moraal, economie, ecologie, recht) moeten de gangbare maatschappelijke opvattingen en bekommernissen in kaart worden gebracht en, vervolgens, naar - onderlinge - waarde worden geschat en beoordeeld.

De onderlinge rangorde tussen die domeinen moet worden bepaald om tot voorrangregels te komen, inzetbaar wanneer ze met elkaar botsen (wat niet uitzonderlijk is). ${ }^{117}$

II6 Zoals door Dhr. Portalis, tijdens de voorbereidende werken van het BW, overtuigend en met groot talent werd aangetoond (Locré, o.c., I, 306).

II7 Niet zonder reden blijkt uit de gebruikte opsomming een rangorde: de politieke ordening overschaduwt alle andere vermits het machtscentrum erdoor wordt gealloceerd en gestructureerd; de sociale ordening organiseert de verhouding tussen de bevolkingsgroepen, onder meer in 
Ondoenbaar? Geenszins, mits de jurist de kennis opbouwt en onderhoudt om per domein te begrijpen waarom de daarin aangetroffen structuren, organisatie, handhaving en financiering tot de beschikbare openbare diensten hebben geleid. ${ }^{\mathrm{I} 8}$

Dat kan niet te veel zijn gevraagd wanneer wordt bedacht dat de openbare diensten van het recht en van de rechtsbedeling precies hun verantwoording in de structuren, organisatie, handhaving en financiering van die - overige - openbare diensten vinden. Recht en rechtsbedeling hebben immers als eerste opdracht ervoor te zorgen dat de samenleving noch meteen, noch op termijn door toedoen van een sluipende ontrafeling haar cohesie verliest.

9I. Gebiedende en verbiedende rechtsregels hebben de laatste decennia vele keren in het zand moeten bijten, tot op het niveau van de hoogste rechtscolleges. ${ }^{\text {II }}$

De afgang van het begrippenpaar ging zo ver dat de leemten, ontstaan ten gevolge van hun neutralisering of wegcijfering, vervolgens met andere begrippen, zoals algemene rechtsbeginselen van grondwettelijke aard, ${ }^{220}$ moesten worden opgevuld om het 'bouwsel' overeind te houden.

Die omweg is overbodig: inhoudelijk gaan de zogenoemde algemene rechtsbeginselen van grondwettelijke aard probleemloos in het begrippenpaar 'openbare orde' en 'goede zeden' op.

Zulks ligt voor de hand: reeds de opstellers van het Burgerlijk Wetboek zagen in dat de basisbeginselen van het publiek recht via het begrippenpaar in het privaat recht doorwerken. ${ }^{\text {22I }}$

De enige 'verdienste' van die zogenoemd algemene beginselen van grondwettelijke aard bestaat erin dat zij 'iets' van het begrippenpaar inzake de politieke ordening veruitwendigen.

Voor het overige verarmen ze, impliciet, de, aan het begrippenpaar toekomende, veel rijkere inhoud, zin en draagwijdte.

In het kader van de rechtsbedeling moet bovendien van de beoordelers kunnen worden verwacht dat zij de toepasselijke gebiedende of verbiedende rechtsregels niet louter ambtshalve kunnen inroepen, maar integendeel ambtshalve moeten inroepen, wanneer hun toepasselijkheid uit de feiten, die hun worden voorgelegd, kan blijken. ${ }^{122}$

functie van hun fysische, psychische en materiële toestand. De morele ordening verwijst naar de gedragsregels die moeten worden gevolgd om de overige ordeningen te handhaven; de economische ordening organiseert het ruilverkeer, dat in overeenstemming met de politieke, sociale en morele ordening moet plaatsvinden. De juridische ordening zet de politieke, sociale, morele en economische ordeningen in rechtsregels om.

II8 Die openbare diensten, alsmede hun kwaliteitsniveau, verschillen immers per samenleving.

II9 O.m. Cass. Io oktober 2002, Pas. 2002, I, I902; Cass. I6 mei 20II, R.W. 20I2-2013, I904 met noot C. Eliaerts.

I20 O.m. A. Lenaerts, o.c., 435-446.

I2I Zie Portalis, Second exposé devant le corps législative du 23 février I803 (Locré, o.c., I, 306).

I22 Zie m.b.t. dat vraagstuk: B. Allemeersch, o.c., I88-I96; B. Cattoir, o.c., 3I-33. 
Hoewel niet steeds duidelijk blijkt op Europees niveau te worden aangenomen dat de beoordeler ambtshalve de rechtsregels van Europese oorsprong moet aanvoeren, die de consument beschermen. ${ }^{123}$

Indien de consument bescherming verdient, is de verklaring daarvan niet te zoeken in de persoon van deze of gene consument, maar wel in de plaats en de relevantie van consumenten en, meer nog, van consumptie in samenlevingsperspectief. Hoe dan ook, er bestaat geen reden om de verplichting tot het ambtshalve aanvoeren te beperken tot zogenoemde dwingende of imperatieve rechtsregels dan wel tot Europese rechtsregels.

In het kader van de openbare dienst van de rechtsbedeling moet dus van de beoordelers worden verwacht dat zij de hand aan de gebiedende of verbiedende rechtsregels houden.

Gelet op hun kennis en ervaring moeten zij er attent op zijn en onderzoeken of uit de hun voorgelegde feiten niet blijkt dat één of meer rechtsregels van gebiedend/ verbiedend recht in het geschil relevant kunnen zijn.

In functie daarvan moeten zij de partijen kunnen ondervragen en hun ertoe kunnen verplichten, gebeurlijk onder een dwangsom die aan de overheid ten goede moet kunnen komen, om bijkomende inlichtingen te verschaffen en/of bijkomende stukken voor te leggen.

Het is moeilijk dan wel in het geheel niet te verantwoorden dat procespartijen van de rechtsbedeling gebruik zouden kunnen maken om hun geschil, in strijd met gebiedende/verbiedende rechtsregels van openbare orde/goede zeden, door een beoordeler te laten beslechten.

Daaruit moet eveneens volgen dat de beoordeler die nalaat een toepasselijke gebiedende of verbiedende rechtsregel ambtshalve in te roepen, daarmee in elke stand van de procedure, inclusief de cassatieprocedure, moet kunnen worden geconfronteerd.

92. Een nauwkeurige invulling van het begrippenpaar is niet enkel nodig om te kunnen bepalen wanneer een rechtsregel de openbare orde dan wel de goede zeden raakt, maar ook om met de algemene begrippen openbare orde/goede zeden overweg te kunnen.

Zoals onder meer uit het Burgerlijk Wetboek, het Unieverdrag en het EVRM blijkt, bestaan er naast de gebiedende en verbiedende rechtsregels ook algemene begrippen 'openbare orde' en 'goede zeden', die trouwens voorrang hebben wanneer contractuele clausules (artikel $6 \mathrm{BW}$ ), dan wel de verdragsmatig erkende of toegekende vrijheden en/of rechten (het Unieverdrag en het EVRM) ermee botsen.

Die voorrang verliest elke betekenis wanneer het begrippenpaar tot een paar casussen wordt beperkt en, voor het overige, oningevuld wordt gelaten.

I23 Zie HvJ C-243/o8, Pannon, Jur. 2009, I-047I3. 
De boodschap is derhalve dat juristen zich aan schuldig verzuim bezondigen, wanneer ze, om welke reden ook, de samenleving in de steek laten door de openbare orde/de goede zeden zo goed als inhoudsloos te laten.

Dat verzuim heeft als rechtstreeks gevolg dat aan de individuele vrijheid, aan het dikke-ik, meer armslag wordt gegund dan wanneer het begrippenpaar een sluitende en gebruiksklare bepaling krijgt.

Juristen moeten er een punt van eer van maken om zich voor een precieze en sluitende omschrijving van openbare orde/goede zeden in te zetten.

Overigens, door hun kiezen op elkaar te houden wanneer de vraag naar een gebruiksklare en sluitende invulling van het begrippenpaar ter sprake komt, arbitreren de juristen reeds tussen het collectief (samenlevings)belang en het individuele belang (het dikke-ik), terwijl ze om hun stilzwijgen te rechtvaardigen nochtans bij hoog en bij laag aanvoeren dat het niet aan hen (maar wel aan de beleidsmakers) zou toekomen om tot die arbitrage over te gaan.

93. Daarbij is nogmaals te benadrukken ${ }^{124}$ dat de juristen erin slagen heel wat moeilijker begrippen dan de openbare orde/de goede zeden van een werkzame definitie te voorzien.

De bewering dat het een zogenoemd onmogelijke opdracht zou zijn om voor het begrippenpaar een criterium uit te werken, houdt dan ook geen steek.

Om zulks te illustreren, volstaat het naar het gangbare schade- en causaliteitsbegrip te verwijzen.

Opgevat als het negatieve verschil (opzichtens een waarde) tussen de toestand van het slachtoffer na de onrechtmatige daad (zijn actuele toestand) en de toestand waarin het zich bij ontstentenis daarvan zou hebben bevonden (zijn hypothetische toestand), ${ }^{125}$ maakt het schadebegrip het noodzakelijk zich over de werkelijke en de virtuele toekomst - eventueel over zeer lange termijn - uit te spreken.

De actuele toestand is immers niet beperkt tot het tijdstip waarop de beoordeler uitspraak doet, maar loopt door, gebeurlijk tot de volledige levensduur van het slachtoffer.

De toekomst is evenwel, per definitie, onkenbaar.

De hypothetische toestand bakt het nog bruiner; precies omwille van de onrechtmatige daad doet de hypothetische toestand vanaf de onrechtmatige daad tot de, in die hypothese, gehele levensduur van het slachtoffer, zich immers niet eens voor. Het onbekende/het niet gebeurde vaststellen is een onmogelijke opdracht.

I24 Zie hiervoor nr. 84 .

I25 D. de Callatay en N. Estienne, 'La responsabilité civile', Chronique de jurisprudence 1996-2007, II, Le dommage, Brussel, Larcier, 2009, 57; T. Vansweevelt en B. Weyts, o.c., 633. 
Fluitend lopen de juristen nochtans rond die moeilijkheden: zij hebben het schadebegrip sluitend omschreven en passen het achteloos toe, dag in dag uit.

Fysici en chemici weten dat wanneer in een ketting van gebeurtenissen die tot een welbepaald resultaat leiden, één gebeurtenis geheel of deels wordt verwijderd of gewijzigd, niets daarna nog op dezelfde wijze verloopt: de relativiteitstheorie staat daarvoor.

Wanneer ze bepalen of een welbepaalde onrechtmatige daad die zich steeds in een ketting van gebeurtenissen voordoet, al dan niet een welbepaalde schade heeft veroorzaakt, hebben de juristen daaraan evenwel geen boodschap.

Zij menen dat zij, gebruik makend van het zogenoemd rechtmatig alternatief en/of van de, daaraan ten grondslag liggende waardeoordelen, wel in staat zijn te bepalen of de in aanmerking genomen schade zich, al dan niet, nog (op dezelfde wijze) bij gebreke aan de onrechtmatige daad zou hebben voorgedaan.

$\mathrm{Zij}$ nemen aldus aan dat in de ketting van gebeurtenissen al het overige bij het oude zou zijn gebleven, wanneer de onrechtmatige daad wordt weggedacht of door een rechtmatige daad wordt vervangen. Wanneer zij tot de 'bevinding' komen dat de schade (geheel of minstens gedeeltelijk) achterwege zou zijn gebleven, besluiten ze tot causaliteit. ${ }^{126}$

94. Begrippen die overduidelijk met onbekenden zijn bezaaid, blijken aldus door juristen moeiteloos met een sluitende, gebruiksklare omschrijving te worden bedacht.

Openbare orde/goede zeden daarentegen doen geen beroep op onbekenden: zij verwijzen naar bestaande toestanden die zich in de samenleving voordoen en die op een onder meer politieke, sociale, morele, economische, juridische, enz. structuur, organisatie, handhaving en financiering berusten.

De kenbaarheid daarvan is niet ernstig te betwisten: gissingen over eventualiteiten, over een toekomstig, al dan niet virtueel verloop, zijn overbodig.

Met - aartsmoeilijke - schade- en causaliteitsbeoordelingen, die aan de lopende band waardeoordelen integreren, hebben de juristen geen last.

De openbare orde/de goede zeden van een werkbare en sluitende definitie voorzien, daarbij steunend op maatschappelijk gangbare, onder meer politieke, sociale, morele, economische, juridische, enz. opvattingen en bekommernissen, zou hun krachten evenwel te boven gaan.

Zoals hiervoor is benadrukt volstaat het over de grenzen van de formele rechtsbronnen te kijken en voor de materiële rechtsbronnen enige belangstelling aan de dag te leggen om over onder meer de politieke, sociale, morele, economische en juridische

I26 B. Dubuisson e.a., o.c., 32I-335; T. Vansweevelt en B. Weyts, o.c., 775-799. 
openbare orde en goede zeden zinnig stelling te kunnen nemen en, op grond daarvan, bruikbare en sluitende omschrijvingen uit te werken.

Het zal de juristen niet enkel voeling met de samenleving geven, die ze behoren te dienen, maar hen ook toelaten om de aan het begrippenpaar in, onder meer, het privaat recht toekomende functie te concretiseren.

\subsubsection{Afrekening met open/vage begrippen}

95. Een even grote bekommernis zowel voor de regelgevers, als, daaraan ondergeschikt, de beoordelers bestaat erin dat zij in rechtsregels, respectievelijk uitspraken geen open of vage begrippen opnemen.

Aan contractspartijen wordt door juristen vermanend gezegd dat zij zich klaar en duidelijk $\mathrm{k}^{127}$ moeten uitdrukken. Daaraan tekortkomen wordt de partijen niet in dank afgenomen, zoals uit artikel II62 $\mathrm{BW}^{\mathrm{I2} 8}$ blijkt.

Waarom zou die elementaire voorzorg niet voor regelgevers en/of beoordelers gelden?

Bezwaard met één of meer open en/of vage begrippen wordt de rechtsregel of de uitspraak zelf open en/of vaag, zolang de inhoud van het open en/of vaag begrip niet is ingevuld.

Die omschrijving wordt in het kader van de rechtsbedeling zonder meer aan de beoordeler overgelaten.

Veel goeds kan daarvan niet komen: vermits de rechtsregel in de onderzochte hypothese open, dan wel vage begrippen bevat, volstaat het voor de beoordeler om in de uitspraak naar dit open/vage begrip, in de ene of andere zin, te verwijzen om zijn beslissing wettelijk te rechtvaardigen.

Afgezien van een zogenoemd wettelijkheidstoezicht ${ }^{129}$ hoeft de beoordeler zich geen zorgen te maken: de toepassing die hij/zij van het open/vage begrip maakt, wordt gemakshalve als een feitelijke beoordeling afgedaan.

96. Dit is van het slechte te veel: een opeenstapeling van 'misverstanden', die van de rechtsregel en de rechtsbedeling een misplaatste grap dreigen te maken.

De toepassing die de beoordeler van het open/vage begrip maakt, wordt feitelijk genoemd omdat het door hem/haar in de rechtsregel aangetroffen begrip geen inhoud kreeg toebedeeld; een criterium dat toelaat te bepalen of de - ingeroepen en bewezen geachte - feiten aan het begrip beantwoorden, ontbreekt immers.

I27 Wat andermaal een kwestie van interpretatie is.

I28 Artikel II62 BW: in geval van twijfel wordt de overeenkomst uitgelegd ten nadele van hem die bedongen heeft en ten voordele van hem die zich verbonden heeft.

I29 Inhoudend dat wordt bepaald (interpretatie!) of de beoordeler, op grond van zijn/haar feitelijke vaststellingen, al dan niet kon beslissen dat aan het open/vaag begrip niet, dan wel is voldaan. De wettelijkheidsbeoordeler kan aldus zijn beoordeling van de feiten op die van de feitenbeoordeler laten voorgaan. 
De beoordeler moet, voortgaande op zijn/haar taalkennis en zijn/haar kennis van de interpretatieregels, ${ }^{130}$ bepalen of de aangevoerde en bewezen geachte feiten, het open/vage begrip, al dan niet doen aanslaan.

In wezen gaat het niet om een feitelijke beoordeling, maar om een juridische kwalificatie die, bij ontstentenis van voorafgaand criterium, oncontroleerbaar is.

Het wettelijkheidstoezicht dat daarop in cassatie, mits dat buitengewone rechtsmiddel wordt aangewend, kan worden uitgeoefend, verandert daaraan weinig.

De hoger geplaatste beoordeler kan - zonder verdere toelichting - zijn/haar beoordeling en toepassing van het open/vage begrip in de plaats van de aangevochten beoordeling en toepassing stellen.

Rechtsregels die met open/vage begrippen werken, zijn drijfzand: ze wekken de indruk van vaste grond, maar erop voortgaan gaat met onvoorspelbaarheid gepaard. Het is immers de - in laatste aanleg tussenkomende - beoordeler die naar eigen inzichten aan het open/vage begrip de concrete betekenis zal toekennen, op grond waarvan hij/zij tussen de partijen de afrekening maakt.

Die omschrijving is onontbeerlijk om de rechtsregel te kunnen toepassen, maar heeft de vluchtigheid van een parfum. De beoordeler, handelend zonder de rugdekking van een definitie, kan volstaan met een verwijzing naar het in de rechtsregel voorkomende open/vage begrip, dat hij/zij al dan niet toepast. Het potje van de rechtsbedeling blijft daardoor dicht: alleen de beoordeler zou kunnen uitleggen waarom hij/zij aan het open/vage begrip eerder deze dan een andere betekenis heeft toegekend. De partijen en derden blijven in het ongewisse: zij moeten gissen en missen. ${ }^{\mathrm{I} 3 \mathrm{I}}$

97. De punctuele toepassingen die de beoordelers van open/vage begrippen maken, leiden tot gedragsregels met meerdere verschijningsvormen. De ontstentenis van precieze begripsomschrijving heeft immers tot gevolg dat niet kan worden gegarandeerd dat de begripsinvulling door één beoordeler in min of meerdere mate met die door een andere beoordeler zal overeenkomen. Dat leidt ertoe dat, op basis van eenzelfde open/vaag begrip, uiteenlopende gedragingen van de ermee geconfronteerde rechtssubjecten zullen worden verwacht.

Vanuit de luie stoel kan de opmerking komen dat van wettelijke begripsomschrijvingen niet te veel is te verwachten; ook omschreven begrippen blijven interpretatie en bijkomende omschrijving vergen.

Meerdere kanttekeningen dringen zich nochtans op. Het komt, vooreerst, aan de wetgevers toe om de begrippen die zij in wettelijke rechtsregels aanwenden, zo nauwkeurig mogelijk te omschrijven, vermits hun bedoeling moet worden achterhaald.

I30 Zie hiervoor nr. 23.

I3I Zie L. Cornelis, 'De achtereenkomst', in R. Feltkamp en F. Vandenbossche (eds.), Wilsautonomie, contracturijheid en ondernemingscontracten, Brussel, Anthemis-Intersentia, 20II, 5I-85. 
Zulks behoort niet alleen tot de kern van de opdracht die zij - binnen de politieke orde - hebben aanvaard (en dus hebben uit te voeren), maar strookt ook met de vaststelling dat zij - naar inzetbare middelen - het best zijn uitgerust om tot weloverwogen en maatschappelijk verantwoorde begripsomschrijvingen te komen.

Indien die regelgevers daarnaar geen oren (zouden) hebben, bestaat het alternatief erin, zoals bij de interpretatie van wettelijk omschreven begrippen het geval is, dat de beoordelers, in het bijzonder de rechterlijke macht, via jurisprudentiële rechtsregels de zeepbellen waarmee open/vage begrippen vergelijkbaar zijn, doorprikken en vervangen door steeds nauwkeuriger begripsomschrijvingen, er tegelijk voor zorgend dat de eraan toegekende inhoud met het wetgevend initiatief verenigbaar blijft.

98. Er bestaat verder een groot verschil tussen een open/vaag begrip waaraan de regelgever geen omschrijving heeft gegeven en een begrip dat door de regelgever mogelijk met een vage omschrijving werd bedacht, dat op basis daarvoor voor jurisprudentiële uitwerking vatbaar is.

Wanneer de wetgever voorschrijft dat er 'passend' of 'redelijk' moet worden gehandeld, ${ }^{132}$ doch nalaat te bepalen wat er nodig is om passend of redelijk te handelen (en er daartoe evenmin op jurisprudentiële rechtsregels een beroep is te doen), staan zowel de rechtssubjecten als de juristen voor vraagtekens. Wordt daarmee verwezen naar de wijze waarop een normaal voorzichtig en redelijk mens (dan wel professioneel), in dezelfde omstandigheden geplaatst, zou hebben gehandeld of is er meer aan de hand? Als er slechts naar de algemene zorgvuldigheidsnorm wordt verwezen, waarom werd dit concept dan niet gebruikt? Wijst zulks er al dan niet op dat de toepasselijke gedragsnorm volgens andere parameters is te bepalen?

Als er meer aan de hand is, welke zijn dan de feitelijke of juridische elementen die ten aanzien van de algemene zorgvuldigheidsnorm bijkomend bij de beoordeling zijn te betrekken, het redelijke van het onredelijke?

Kortom, het open/vage begrip 'passend' of 'redelijk' maakt alles en het tegendeel ervan mogelijk, precies omdat een omschrijving van het criterium dat toelaat het passende van het onpassende, het redelijke van het onredelijke te onderscheiden, achterwege is gebleven.

99. Het (contractueel/buitencontractueel) foutbegrip was initieel in het Burgerlijk Wetboek een open/vaag begrip, dat vervolgens door jurisprudentiële rechtsregels

I32 De begrippen 'passend' en 'redelijk' komen regelmatig voor in wettelijke rechtsregels. Het GEKR (Gemeenschappelijk Europees Kooprecht) en de bankenwet (Wet van 25 april 20I4 op het statuut van en het toezicht op kredietinstellingen, BS 7 mei 20I4) zijn daarvan voorbeelden. Het zijn vanzelfsprekend niet de enige open/vage begrippen die in rechtsregels voorkomen. Leerrijk is, in dat verband, de diepgravende analyse van Y. Thierry (Discriminatie en verzekering, Antwerpen, Intersentia, 20II, 757 p.), die blootlegt (p. 235-337) welke complexe gedragsregels (in de toepassing ervan, op de verzekeringssector) in het gelijkheidsbeginsel besloten liggen. Daarop vooruitlopen in een concreet geschil is een schier onoverkomelijke opdracht. 
werd omschreven, zowel op het vlak van de toerekeningsvatbaarheid als van de normovertreding. ${ }^{133}$

Wanneer een beoordeler moet bepalen of zich bij rechtsregelovertreding al dan niet een fout heeft voorgedaan, weet hij/zij welk criterium/patroon daarbij is te gebruiken. Het volstaat niet te bepalen of er al dan niet passend of redelijk werd gehandeld: de te volgen gedachtegang moet het keurslijf van de jurisprudentiële omschrijving doorlopen.

Daarmee zijn, zoals uit de rechtspraak blijkt, weliswaar niet alle problemen van de baan, maar dat keurslijf zorgt zowel voor coherentie tussen, als voor kenbaarheid en controleerbaarheid van de beslissingen.

Regelgevers en/of beoordelers die nalaten de begrippen te omschrijven die zij als toepassingsvoorwaarden hetzij in rechtsregels opnemen, hetzij al dan niet in hun uitspraak toepassen, kwijten zich niet van de taken die hun in het kader van openbare diensten zijn opgedragen en die zij - met kennis van zaken - hebben aanvaard.

Het spreekt voor zich dat van de beoefenaars van de rechtswetenschap, die tot de beoordelers behoren, daarbij een belangrijke bijdrage is te verwachten.

\subsubsection{De onhoudbaarheid van spreidstanden}

I0o. De Westerse samenleving wordt door een spreidstand gekenmerkt die niet zonder risico is.

Die spreidstand is in de Verenigde Staten het grootst. ${ }^{\mathrm{I} 4}$ Die wereldmacht beroept zich op het democratisch model, gebaseerd op individuele vrijheid en gelijkheid, maar het waarheidsgehalte daarvan is sinds lang aan het afbrokkelen. Die voorstelling van zaken is meer op een commerciële slogan beginnen lijken, die wordt gebruikt om de werkelijke toedracht af te schermen.

De politieke, sociale, economische en financiële macht is niet langer in handen van de meerderheid van de bevolking maar wel geconcentreerd bij een steeds kleiner percentage van de bevolking, door Sandel 'the affluent' genoemd. ${ }^{135}$

De democratisch geïnspireerde structuren en organisatie blijven ogenschijnlijk bestaan, maar de zogenaamd democratisch verkozenen kunnen niet de koers varen die de meerderheid zou wensen of die haar belangen zou dienen.

De verkozenen moeten hun beleid op de eerste plaats op de belangen van de elite afstemmen, een minderheid gekenmerkt door disproportionele rijkdom. Die belangen mogen door het overheidsbeleid niet in het gedrang worden gebracht, De elite verwacht integendeel dat haar belangen erdoor worden bevorderd.

I33 Zie o.m. T. Vansweevelt en B. Weyts, o.c., I25-I63; Dubuisson e.a., o.c., 2I-4I.

I34 Al Gore, o.c., 92-I39; J. Stiglitz, o.c., I48-I82.

I35 M. Sandel (What money can't buy, o.c.) beschrijft talloze, dagdagelijkse symptomen van die machtsverschuiving. 
In de Verenigde Staten is de greep van de elite op de overheid overduidelijk zichtbaar, geïnstitutionaliseerd door de (toegelaten) financiering van de verkiezingscampagnes door die elite. ${ }^{136}$

In West-Europa loopt het nog niet zo'n vaart, maar het zou verkeerd zijn te denken dat de spreidstand die het Amerikaans politiek bestel kenmerkt, er afwezig zou zijn.

Ook in West-Europa moest het machtscentrum door de politieke meerderheid enige decennia geleden aan de elite worden afgestaan. ${ }^{137}$ Het resultaat lijkt hier en elders eerder oligarchisch, dan democratisch. ${ }^{138}$

Ior. Die nog steeds voortgaande machtsverschuiving heeft als kenmerk een toenemende verzwakking van de structuren, de organisatie, de handhaving en financiering van de democratisch georganiseerde overheid en van de, in dat kader, tot stand gebrachte openbare diensten.

Het leidende beginsel blijkt daarbij te zijn dat er aan de centrale overheid zo veel mogelijk macht wordt ontnomen: verdeel en heers.

De (politieke) macht wordt bij voorkeur over verschillende overheden verdeeld, elk bevoegd op een zo beperkt mogelijk jachtgebied, of, nog beter, aan private rechtssubjecten die de plaats van de overheid, al dan niet gedeeld, overnemen.

De maatschappelijk sterksten scoren daarmee dubbel: de macht die van de overheid naar de private sector overgaat, betekent toegenomen mogelijkheden om het eigenbelang op het collectieve belang te laten voorgaan.

Bovendien leidt de tussen overheden opgedeelde macht, zo leert hun jarenlange ervaring, ernaar dat die overheden zich met elkaar meten, dat er gaten in het overheidsoptreden vallen, dat de overheid overzicht en (algemene) kennis kwijtspeelt die nodig zijn om tot een coherent beleid te komen. Al die overheidstekorten of tekortkomingen worden met dank door hen begroet en benut.

Hoe meer spreidstanden er zich voordoen, waardoor het politieke model op papier overleeft maar door de feiten is achterhaald, hoe beter de maatschappelijk sterksten hun belangen met succes kunnen behartigen.

I02. Het is tijd om de uit haar voegen barstende verhouding tussen wetgevers en beoordelers vanuit dat algemeen maatschappelijk perspectief te herevalueren.

Het pleidooi voor zogenoemd beleid door de rechter, waarvan wordt aangenomen dat het ten aanzien aan de wettelijke rechtsregels zowel aanvullend, als beperkend en correctief kan zijn, komt er immers op neer dat de regulering geheel of deels aan de wetgevers ontsnapt. ${ }^{339}$

I36 Al Gore, o.c., I05-I39.

I37 L. Huysse, o.c., 56-II3; T. Todorov, o.c., 227-246.

I38 A. Cotta, Le règne des oligarchies, Mesnil-sur-l'Estrée, Plon, 20II, 2I2 p.; G. Bronner, La démocratie des crédules, Paris, PUF, 2013, 394 p.

I39 Dat was geenszins de bedoeling van W. Van Gerven (zie Het beleid van de rechter, Antwerpen, Standaard Wetenschappelijke Uitgeverij, I973, I6I). 
De fractionering van de regulering is des te diepgaander wanneer dat zogenoemde beleid op het niveau van de feitenrechter wordt gesitueerd..$^{10}$

De feitenbeoordeler beschikt mogelijk over veel goede wil, maar niet over de middelen of zelfs de legitimiteit om na te gaan of de maatregelen die hij/zij via zijn/haar beslissing wenselijk acht, maatschappelijk inpasbaar of verantwoordbaar zijn.

Het is mogelijk dat de uitspraak van de beoordeler, georiënteerd op het beleid dat hij/zij benaarstigt, onder omstandigheden voor de bij het geschil betrokken partijen naar een voor een van hen beter aangepaste uitspraak leidt, dan met de toepassing van de rechtsregels het geval zou zijn. Dat is evenwel niet steeds het geval en bovendien is zeker dat de partijen, betrokken bij het geschil, het daarover fundamenteel oneens zullen blijven. ${ }^{\mathrm{I} I \mathrm{r}}$

Daarboven stapelen zich de volgende donkere wolken op: het beleid van één beoordeler kan met betrekking tot dezelfde feitelijke omstandigheden sterk van het beleid van een andere beoordeler verschillen. Het 'beleid van de rechter' heeft aldus op het vlak van het gelijkheidsbeginsel een hoge prijs, met de verzwarende omstandigheid dat de concrete inhoud van dat rechterlijk beleid meestal onuitgesproken en dus versluierd blijft.

I03. Vooral rijst de vraag waarom het de voorkeur zou verdienen aan een geschil een oplossing te geven, die naar het oordeel (of zelfs beleid) van de beoordeler beter aan de feiten of aan belangen van één geschilvoerende partij kan zijn aangepast, wanneer één of meer rechtsregels beschikbaar en toepasselijk zijn die tot een andere beslissing nopen?

De spreidstand is daarbij onmiskenbaar: op papier komt zulks aan de beoordeler niet toe, ${ }^{142}$ maar dat papier blijkt nog weinig indruk te maken. De beoordelers vullen de toepasselijke rechtsregels aan, beperken en corrigeren ze dat het een lieve lust is. Via subjectieve rechten, vrijheden, belangenafwegingen, enz. bevrijden ze zich van het juk van de rechtsregels die tot een anekdote in het rechtsbedelingsproces verkleuren.

Wie is daarmee gediend? Mogelijk één der procespartijen; mogelijk de beoordeler... maar verder?

Bestaat de rechtsbedeling in hun belang? Beantwoordt de rechtsbedeling aan haar finaliteit wanneer zij één der procespartijen en/of de beoordeler gelukkiger maakt?

Zonder de minste twijfel is dat niet het geval: als openbare dienst strekt de rechtsbedeling ertoe geschillen te beslechten om te vermijden dat het uitblijven van beslechting de-bestaande - samenleving al te zeer zou verstoren. Zij handhaaft de samenleving, daarop komt het aan.

I40 Jurisprudentiële rechtsregels verwijzen eveneens naar rechterlijk beleid dat evenwel, per definitie, op algemeenheid, abstractie en duurzaamheid (kenmerken van de rechtsregel) is afgestemd en onder meer daardoor aan de hierna volgende kritieken ontsnappen.

I4I De procespartij die daarvan geniet, zal die benadering bijvallen; de procespartij die daarmee het deksel op de neus krijgt, zal het volkomen anders zien.

I42 Artikel 6 Ger.W. verzet zich daartegen: de rechter mag geen uitspraak doen bij wege van algemene en als regel geldende beschikking. 
I04. Aan de beoordeler, weze het in het kader van een individueel, bijzonder en concreet geschil, toelaten om tot een oplossing te komen op grond van een zogenoemd beleid dat aanvullend of corrigerend ten aanzien van de toepasselijke rechtsregels kan zijn, past daarin niet.

Waarom werd die weg dan toch ingeslagen? Waar liggen de baten ervan?

Zonder twijfel hebben de aanvullende, beperkende dan wel corrigerende beoordelers het goed voor.

Omdat het met de toepasselijke rechtsregel(s) te bereiken resultaat - naar hun oordeel - onbevredigend is, voelen ze de noodzaak tot aanvulling, beperking of correctie.

Zij doen dat 'in eer en geweten', varend op hun (individueel) rechtvaardigheids- of billijkheidsgevoel, waardoor zij vaak de zwakkere tegen de sterkere in bescherming nemen.

Helaas, ook de weg naar de hel blijkt met goede voornemens geplaveid.

Goed willen doen garandeert het ermee te bereiken resultaat niet.

Het is mogelijk dat aldus in het kader van een welbepaald geschil een 'beter' resultaat dan met de koele toepassing van de rechtsregel(s) wordt bereikt, maar op maatschappelijk vlak stelt dat betere resultaat weinig voor. Het gaat integendeel met averechtse effecten gepaard.

Op zijn eentje, via relatieve, punctuele en anekdotische rechtsbedeling voor een beter rechtsgebeuren willen zorgen, is vechten tegen windmolens. Mogelijk een nobele activiteit, maar wat levert het op voor de personen die, in vergelijkbare omstandigheden, geen procedure - om welke reden ook - kunnen of willen inleiden, dan wel op een minder milde beoordeler 'vallen'?

De beoordeler-weldoener wekt tegelijk de indruk dat de samenleving door zijn/ haar initiatief 'passend', 'behoorlijk' wordt georganiseerd, terwijl hij/zij in wezen de rechtsregel en het rechtsgebeuren slechts fragiliseert door de onderliggende boodschap dat alles (zo niet zeer veel) van zijn/haar beoordeling af hangt.

Wetgevers bedienen zich bovendien graag van die indruk om niet tussen te komen, ${ }^{143}$ maar het zijn de maatschappelijk sterksten die overduidelijk bij de grootst mogelijke speelruimte ten aanzien van rechtsregel en rechtsbedeling het meeste belang hebben.

Hoe groter de speelruimte die hun wordt gelaten, hoe meer ze die in eigen belang kunnen benutten.

Zij en hun raadslieden kunnen aan de feitenbeoordeler die met eigen beleid uitpakt, steeds nieuwe benaderingen voorstellen, wanneer een rechtsregel hen in verlegenheid brengt. Bovendien, ook al kan het eens verkeerd aflopen, treuren moeten ze niet: één veldslag verloren, is het verlies van de oorlog niet. Dezelfde veldslag kan

I43 Zij verantwoorden hun inactiviteit dan wel ondermaats werken met de bewering dat de rechters het wel oplossen... 
voor een andere beoordeler met een ander beleid worden overgedaan en daar een gans ander verloop krijgen.

Onder het - opgehemelde - beleid van de rechter loert aldus een kwalijk conflict tussen collectief en eigenbelang, met een manifest risico van belangenvermenging in hoofde van de raadslieden die zich in een openbare dienst inschakelen, dat best gedetailleerd in kaart wordt gebracht en opgevangen.

Met die rechtzetting van de belangeninversie kunnen er maatschappelijke schokken en bevingen gepaard gaan, maar zij zijn te verkiezen boven de verdere teloorgang van het democratisch model en de razernij die zulks, vroeg of laat, veroorzaakt.

I05. De rechtsbedeling moet dus terug doen wat het woord aangeeft: zij moet plaatsvinden op grond van het positief recht, zijnde een geheel van algemene, abstracte en duurzame rechtsregels, uitgaande van bevoegde overheden.

Wil het democratisch model overleven, dan moet tegelijk van die overheden worden geëist dat zij eigenbelangen aan collectief belang ondergeschikt maken, dat hun beleid de collectiviteit en geen minderheid dient en dat zij uit de schaduw en de voetsporen van de maatschappelijk sterksten treden.

Met wettelijke rechtsregels en een daarop afgestemde rechtsbedeling is dat geenszins een fata morgana.

Jurisprudentiële rechtsregels moeten daartoe steeds binnen het kader van de wettelijke rechtsregel zijn te situeren, waarop zij voortbouwen. Conflicten tussen wettelijke en jurisprudentiële rechtsregels moeten in het voordeel van de eerstgenoemde worden beslecht.

Subjectieve rechten zijn en blijven handige instrumenten om de toepasselijke rechtsregels in functie van de zich voordoende feitelijke omstandigheden te concretiseren.

De rechtsbedeling op grond van subjectieve rechten vergt echter dat zij slechts naar een macht verwijzen, die steeds naar inhoud en draagwijdte met de daaraan onderliggende rechtsregels verenigbaar is.

Gedragsregels, bepaald op grond van subjectieve rechten, die niet met de onderliggende rechtsregels verenigbaar zijn, zijn buiten beschouwing te laten.

Zulks geldt nog meer met betrekking tot gedragsregels die uit zogenoemde rechterlijke belangenafwegingen voortkomen.

Ook die gedragsregels moeten hun verantwoording in onderliggende, toepasselijke rechtsregels vinden. Is dat niet het geval, dan horen zij niet bij de rechtsbedeling te worden betrokken.

Kortom, jurisprudentiële rechtsregels, subjectieve rechten en/of belangenafwegingen moeten hun verantwoording in voorafbestaande, toepasselijke rechtsregels vinden, waarmee zij verenigbaar moeten zijn. De punctuele, individuele en concrete gedragsregel, op basis waarvan de beoordeler uitspraak doet, ongeacht of die uit een rechtsregel, een subjectief recht of een belangenafweging wordt afgeleid, moet 
altijd zijn verantwoording in een of meer toepasselijke, algemene, abstracte en duurzame rechtsregels vinden die van bevoegde wetgever(s) uitgaan.

Door de feitenbeoordeler in het leven geroepen beperkingen van, dan wel correcties op de toepasselijke wettelijke en/of, daaraan ondergeschikt, jurisprudentiële rechtsregels, zijn daarmee per definitie onverenigbaar en zorgen voor een spreidstand, waardoor de rechtsbedeling met het positief recht conflicteert.

\subsubsection{Werk voor de boeg}

Io6. De hiervoor sterk aangeprezen herbronning van het rechtsgebeuren moet tot toenemende vereenvoudiging en bevattelijkheid leiden.

Toegegeven, de mening dat in de rechtsbedeling aan de wettelijke rechtsregels voorrang toekomt, dat in rechtsregels geen open, dan wel vage begrippen horen op te duiken en dat het begrippenpaar openbare orde/goede zeden dringend een bruikbare en sluitende omschrijving behoeft, heeft een hoog theoretisch gehalte.

Die uitgangspunten moeten dus concreet worden uitgewerkt. Zij zijn daartoe geschikt, afgezien van hun richtinggevend karakter.

Per (private) rechtstak zijn de rechtsregels (en/of de gedragsregels ${ }^{144}$ ) te identificeren, waardoor het samenlevingsbelang aan eigenbelang ondergeschikt is gemaakt en waardoor, op termijn en/of bij veralgemening, de gangbare maatschappelijke, onder meer politieke, sociale, morele, economische en juridische opvattingen of bekommernissen in het gedrang komen.

Eenmaal die identificatie is gebeurd, is de belangeninversie te corrigeren door de rechtsregels die de openbare orde/de goede zeden aanbelangen en de desbetreffende begrippen op het eigenbelang te laten voorgaan.

Het kan zich als een lastige karwei van lange adem aandienen. Noch de maatschappelijke relevantie, noch de ervan uitgaande uitdaging kan evenwel ernstig worden betwist.

Die opdracht gaat de krachten van het enkele individu te boven: een aanpak in groepsverband dringt zich op, waarbij de juristen bovendien het verband met andere menswetenschappen niet uit het oog mogen verliezen. ${ }^{\text {I45 }}$

I44 Uit de rechtsregels die, in beginsel, ge- of verboden bevatten, worden in confrontatie met de feitelijke omstandigheden, waarin hun toepassingsvoorwaarden zich voordoen, door de feitenbeoordelers (concrete) gedragsregels afgeleid, waaraan het gedrag van de ene, dan wel andere procespartij wordt getoetst, om te bepalen of die toepasselijke rechtsregels al dan niet werden nageleefd.

145 G. Ripert (Les forces créatrices du droit, Paris, LGDJ, I955, 43I p.) en R. Savatier (Les métamorphoses économiques et sociales du droit privé d'aujourd'hui. L'universalisme renouvelé; des disciplines juridiques, Paris, Dalloz, I959, 340 p.) pleitten reeds daarvoor. 
Openbare orde/goede zeden hebben, zoals toegelicht, in het bijzonder een politieke, sociale, morele, economische, enz. inhoud en betekenis, die tot die juridische concepten moeten worden omgebouwd. De klimatologische en ecologische noodwendigheden zijn daarbij noodzakelijk te betrekken. ${ }^{\mathrm{I} 6}$

Met enkele voorbeelden ${ }^{\mathrm{I} 47}$ wordt hierna aangetoond dat de stap van theorie naar praktijk niet bijster groot hoeft te zijn.

c) De mens, maatstaf van het maatschappelijk en rechtsgebeuren

I07. De vraag rijst of in het verenigings- en vennootschapsrecht dan wel in het financieel recht wezens dan wel activiteiten kunnen worden toegelaten, die het menselijk vermogen te boven gaan. ${ }^{\mathrm{I} 48}$

Menselijk leven is door de dood begrensd: daardoor wordt herverdeling van het, tijdens het leven geaccumuleerde vermogen mogelijk, wat niet enkel voor de erfgenamen, maar ook ten opzichte van de samenleving van belang is.

Oorspronkelijk hadden rechtspersonen een bepaalde duur, zodat zij, via ontbinding en vereffening, tot de herverdeling bijdroegen.

Sinds lang is daarin, onder meer ten aanzien van de handelsvennootschappen, verandering gekomen: er werden aldus juridische wezens in het leven geroepen, die - potentieel - onsterfelijk zijn en aldus, ten voordele van hun eigenaars (aandeelhouders), onbeperkte vermogensaccumulatie en -concentratie kunnen nastreven.

Wanneer daaraan hun pathologisch oogmerk wordt toegevoegd, ${ }^{\text {I49 }}$ alsmede de mogelijkheid om het aandelenbezit via andere (even onsterfelijke) vennootschapsconstructies in fiscale en andere paradijzen onder te brengen, blijkt dat private rechtspersonen en hun aandeelhouders een onoverbrugbare voorsprong hebben op de mens die het zonder rechtspersoon moet zien te rooien. Die voorsprong mondt uit in toenemende ongelijkheid tussen de private rechtspersonen (hun eigenaars-aandeelhouders) en de 'achterlopers', die geen vennootschapsvehikel(s) ter beschikking hebben.

De afbouw van de onsterfelijkheid van private rechtspersonen moet dan ook hoog op de agenda worden geplaatst.

Io8. Flitshandel ontregelt de werking van financiële markten. Het begrip verwijst naar handel in financiële instrumenten, die door computermodellen wordt bepaald en gestuurd. De op grond van die modellen 'handelende' computers zijn in staat beslissingen in fracties van seconden te nemen, waar het menselijk vermogen niet bij kan. ${ }^{150}$

Flitshandel dringt het alea van financiële transacties terug en zorgt derhalve voor toenemende vermogensaccumulatie van de gelukkige eigenaar van de computers

I46 O.m. T. Jackson, Prosperity without growth, London, Earthscan, 2009, 2I4 p.

I47 De hierna volgende voorbeelden bouwen voort op eerder en lopend onderzoek van L. Cornelis.

I48 Zie ook N. Bostrom, Superintelligence, Paths, dangers, strategies, Oxford, U.P., 2013, 368 p.

I49 J. Bakan, The corporation, The pathological pursuit of profit and power, NY, Free Press, 2004, 228 p.

I50 M. Lewis, Flash Boys: a wall street revolt, NY, Norton \& Co, 20I4, 288 p. 
(en van zijn aandeelhouders). Dat is precies de reden waarom die handel zich in die zin heeft ontwikkeld.

Vanzelfsprekend zijn computermodellen het resultaat van menselijk vernuft. Zulks geldt ook voor hun inschakeling in het financieel gebeuren. Evenwel blijken ze, eenmaal operationeel, niet op mensenmaat gesneden: geen mens kan zich op de financiële markten met dergelijke computermodellen meten. De uitkomst is, tenzij elektriciteitspanne of computerbug, bij voorbaat gekend.

Dat is een voldoende reden om de flitshandel uit de financiële markten te halen.

Indien het menselijk wezen meent dat het de maatstaf van het gebeuren op de planeet moet zijn, moet zijn samenleving op mensenmaat zijn gesneden om daarmee te sporen.

Met de industrialisering, de informatisering en de robotisering van de samenleving komt dat uitgangspunt onder druk te staan.

'Mensenmaat' houdt immers in dat ieder die tot het menselijk ras behoort en bereid is zich in een samenleving te integreren, daardoor een menswaardig bestaan moet kunnen leiden. De graad van menswaardigheid wordt daarbij bepaald door de toestand waarin de samenleving zich bevindt. ${ }^{15}$

In samenlevingsverband wordt die doelstelling door verdeling en herverdeling van de beschikbare middelen gerealiseerd.

I09. Industrialisering, informatisering en robotisering leiden in de Westerse samenlevingen tot een aanzienlijk verlies aan arbeidsplaatsen en -voorwaarden, waardoor het aan arbeid toekomende deel van het bruto nationaal product hapert en stokt, vaak zonder perspectief op beterschap.

Het bruto nationaal product (BNP) wordt met arbeid en kapitaal verwezenlijkt. Beide componenten worden evenwel via dat BNP onevenredig vergoed. De vergoeding van het kapitaal overtreft de vergoeding van de arbeid.

Indien de vergoeding van het kapitaal de groei van het BNP overtreft $(r>g),{ }^{152}$ bevestigt zulks de ongelijke verdeling van de aan arbeid/kapitaal toekomende vergoedingen.

Die bevinding, tezamen met de vaststelling dat het rendement op het kapitaal stijgt naarmate het kapitaal in omvang toeneemt $(\mathrm{R}>\mathrm{r}),{ }^{\mathrm{1} 53}$ leidt naar exploderende financiële ongelijkheden, die samenlevingsbedreigend kunnen zijn.

Naarmate de arbeid schaarser wordt, neemt de neerwaartse druk op de arbeidsvoorwaarden toe en wordt arbeid 'goedkoper', wat ten goede van de kapitaalverstrekkers komt, tenzij verdelende, dan wel herverdelende mechanismen de daaruit volgende vermogensconcentratie (min of meer) neutraliseren.

I5I Die toestand kan grote verschillen vertonen, wat niet alleen door de geschiedenisboeken, maar ook door hedendaagse waarnemingen wordt bevestigd (zie ook o.m. E.S. Reinert, How rich countries got rich...and why poor countries stay poor, London, Constable, 2007,365 p.).

T. Piketty, o.c., 708-723. 
Wanneer de arbeid steeds schaarser wordt, moet de rechtstreekse verdeling van het BNP via arbeid door onrechtstreekse verdeling van de inkomens en vermogens worden ondersteund/gecompenseerd, waarvoor de overheden moeten instaan om het menswaardig bestaan van de groepsleden te vrijwaren.

Industrialisering, informatisering en robotisering hebben in de samenleving dus slechts een plaats, wanneer tegelijk die herverdeling ter harte wordt genomen.

Wanneer ze, zoals in het kader van flitshandel, louter worden ingezet om eigenbelang te dienen en er niet kan worden verzekerd - zelfs in afwezigheid van bedrieglijk gedrag ${ }^{154}$ - dat het verschijnsel tot de herverdeling van de eruit volgende inkomens en vermogens bijdraagt, ondermijnen ze de op mensenmaat gesneden samenleving in plaats van tot haar handhaving bij te dragen.

De inzet van kennis of van technologie is derhalve met omzichtigheid te benaderen, overigens zelfs in de gezondheidszorg.

Hoe spectaculair de daarmee te verwezenlijken vooruitgang ook kan ogen, zij is op zichzelf ontoereikend om daarop ongeremd in te zetten en alle andere beschouwingen overbodig te achten. Even belangrijk is dat wordt onderzocht in welke mate een welbepaalde medische vooruitgang door de samenleving - rechtstreeks en onrechtstreeks - kan worden geabsorbeerd, ${ }^{155}$ zonder de eraan ten grondslag liggende beginselen aan te tasten.

d) Het kwaadaardig virus van de rechtsregelontwijking

IIo. Een andere - algemene - bekommernis betreft de houding die in het recht en in de rechtsbedeling met betrekking tot rechtsregelontwijking wordt aangenomen.

Van rechtsregelontduiking staat vast dat zij met een risico van sanctie en dwang gepaard gaat, vermits - opzettelijk - een rechtsregel wordt miskend. Met betrekking tot rechtsregelontwijking wordt vaak gedacht en gezegd, zelfs door vooraanstaande juristen, dat daaraan niets onwettig of aanvechtbaar zou zijn: 'wat niet is verboden, is toegelaten'.

Rechtsregelontwijking is dan ook een juridische lucratieve activiteit geworden, die op alle mogelijke manieren en terreinen, in het bijzonder ten gunste van de maatschappelijk sterksten, wordt beoefend.

Om zich rekenschap te geven van de belangeninversie die rechtsregelontwijking kenmerkt, volstaat het aan de fiscale/vennootschapsrechtelijke constructies te

I54 Bedrieglijk gedrag in de samenleving komt meer voor dan in het algemeen (ook in rechte) wordt toegegeven: A. Lenaerts (o.c., 86-315) behandelt meerdere toepassingsgevallen, maar die opsomming is verre van uitputtend.

I55 Zulks geldt onder meer met betrekking tot de (nagestreefde) verlenging van de levensverwachting, waardoor de structuur van de samenleving niet enkel voor de erfgenamen, maar ook voor de overheid (gezondheidszorg, pensioenen en hun financiering) en de planeet verandert. 
denken, die onder meer ${ }^{156}$ de grootste multinationale ondernemingen toelaten omzet en winsten boekhoudkundig naar oorden te delokaliseren, waar de belastingdruk minder hoog is dan op de plaats waar die omzet en winst werden gegenereerd.

Naar die zogenoemd fiscaal- en/of sociaalvriendelijke paradijzen stromen fortuinen en vermogens, die worden onttrokken aan de samenleving waaraan ze hun ontstaan te danken hebben. De lokale economie en overheid kunnen ernaar fluiten. ${ }^{157}$

Geen nood evenwel, via op elkaar voortbouwende constructies en leningen komen die achtergehouden fortuinen, vermogens en hun opbrengsten in handen van zogenoemde institutionele beleggers, die intekenen op de duurbetaalde leningen die de lokale overheden moeten aangaan om hun werking (die van hun openbare diensten) (verder) te kunnen financieren.

Rechtsregelontwijking onttrekt aan de lokale samenleving een wezenlijk deel van de lokale rijkdom, doordat winstgevende en/of vermogende personen en/of entiteiten, proportioneel met de rechtsregelontwijking weigeren tot de financiering en werking van de lokale economie en overheid bij te dragen. De daarmee gepaard gaande ontwrichting en benadeling worden door hen herhaald door de eerder onttrokken middelen toch, maar tegen hoge rendementen, aan de lokale economie en overheid ter beschikking te stellen, die zodoende een tweede maal bij de neus worden genomen.

In een kleinere groep (vereniging/vennootschap) worden de personen die denken zich dergelijk gedrag te kunnen veroorloven, meteen als valsspelers ontmaskerd en uit de groep geweerd. Waarom zou dan in samenlevingsverband zijn te dulden dat personen met eenzelfde gedragspatroon het lef opbrengen, bij hoog en bij laag, te beweren dat zij toch niet vals spelen en dat zij ongestoord hun gang moeten kunnen gaan?

III. De juridische argumentatie als zou in rechte niets tegen rechtsregelontwijking zijn in te brengen, houdt bovendien geen steek.

Rechtsregelontwijking gebeurt immers door middel van rechtshandelingen, vermits de persoon die zich op rechtsregelontwijkend gedrag toelegt, naar rechtsgevolgen streeft die met de in stelling gebrachte en toegepaste rechtsregels, in beginsel, kunnen worden bereikt.

I56 Maar, vanzelfsprekend, niet alleen zij; rechtsregelontwijking is een wereldsport, waaraan zowel vermogende individuen als vermogende verenigingen van personen, met groot enthousiasme, in zeer gediversifieerde vormen deelnemen.

I57 Zie desbetreffend de scherpe analyses van G. Zucman, La richesse cachée des nations, Etude sur les paradis fiscaux, Paris, Seuil, 2013, II4 p.; N. Shaxson, Treasure Islands. Tax havens and the men that stole the world, London, Vintage, 20II, 332 p.; X. Harel, La grande évasion, Arles, Actes sud, 20Io, $3 \mathrm{I} 6 \mathrm{p}$. 
Op rechtshandelingen zelf zijn rechtsregels toepasselijk: het voorwerp en de oorzaak van de - beoogde - verbintenissen moeten onder meer geoorloofd zijn. ${ }^{158}$ Per verbintenis (en zulks strekt zich tegelijk uit tot het daaraan gekoppelde subjectief recht ${ }^{159}$ ) is te bepalen of de (determinerende) beweegredenen van schuldenaar/ schuldeiser, dan wel de met de verbintenis nagestreefde prestatie al dan niet met de gebiedende of verbiedende rechtsregels en met het begrippenpaar openbare orde/ goede zeden stroken.

Wanneer blijkt dat de beweegredenen die tot rechtsregelontwijking leiden, op termijn en/of bij veralgemeende toepassing, de samenlevingsstructuur, organisatie, handhaving of financiering, onder meer politiek, sociaal, moreel of economisch ontwrichten, moet tot strijdigheid met de openbare orde en de goede zeden van de rechtsregelontwijkende rechtshandelingen worden besloten. De vaststelling van hun absolute nietigheid en van de daaraan gekoppelde (buitencontractuele) aansprakelijkheid dringt zich alsdan op.

Ten opzichte van fiscale/sociale rechtsregelontwijking lijkt dat besluit onvermijdbaar.

Rechtsregelontwijking heeft intussen tentakels in alle takken van het privaat recht gekregen. De kwalificatiestrijd met betrekking tot de 'credit default swap'160 om die overeenkomst, ten onrechte, tot de zogenoemde financiële producten te rekenen, terwijl het gaat over een verzekeringsproduct vergelijkbaar met de kredietverzekering, ${ }^{16 \mathrm{I}}$ is hiervan een treffend voorbeeld.

\section{e) Aansprakelijkheidstekorten}

II2. Wie het belang van de fysische/psychische integriteit en van de arbeidsgeschiktheid in het dagelijkse leven kent, kan slechts tot de bevinding komen dat de onderneming (en haar aandeelhouders) beter dan de natuurlijke persoon door het recht en de rechtsbedeling wordt beschermd.

De ondernemingscontinuïteit, de sanctie bij laattijdige betaling... worden beter opgevolgd dan de zorg om bij aantasting van de fysische/psychische integriteit of van de arbeidsgeschiktheid aan de getroffene (en zijn gezin) een bestaan te garanderen, waardoor wordt vermeden dat hij/zij (en hun gezinsleden) maatschappelijk wordt (worden) uitgesloten.

Op papier wordt het slachtoffer door de toepassing van het aansprakelijkheidsrecht, via de schadeloosstelling, in de toestand geplaatst waarin het zich bij ontstentenis van de onrechtmatige daad zou hebben bevonden.

I58 Artikel IIo8 BW.

I59 Verbintenis en vorderingsrecht zijn elkaars spiegelbeeld.

I60 De 'credit default swap' (CDS) verwijst naar een overeenkomst waardoor een persoon het insolvabiliteitsrisico dat een schuldeiser t.a.v. een welbepaalde schuldenaar heeft, van die schuldenaar tegen betaling van een 'premie' overneemt.

I6I Aldus H. Cousy, 'What's in a name: CDS or insurance?', in Finance and law: twins in trouble, te verschijnen bij Intersentia, 20I4. 
De schadevaststelling en -begroting, voornamelijk wat het toekomstig luik betreft, ${ }^{162}$ vergt zoveel 'gissingen' dat vergissingen daarbij onvermijdelijk zijn. ${ }^{163}$

Hoewel beide partijen daaronder kunnen lijden, ${ }^{164}$ zou namelijk de ondervergoeding van het slachtoffer een bron van maatschappelijke bekommernis moeten zijn.

De ontoereikendheid van de schadevergoeding zal immers pas op latere leeftijd van het slachtoffer acuut worden. Die onvergoed gebleven schade zal alsdan door het slachtoffer, door zijn gezin of familie, door vrienden of door de samenleving ten laste zijn te nemen.

Het aansprakelijkheidsrecht verdient beter en kan ook beter. Door de schade en de schadevergoeding periodiek te controleren en herzienbaar te maken ${ }^{165}$ en door aan het slachtoffer de afdwingbare verplichting op te leggen om de vergoeding tot het herstel van de schade aan te wenden ${ }^{166}$ kan de schadevergoeding veel beter op de werkelijke toestand van het slachtoffer, gedurende zijn volledige levensloop, aansluiten dan nu het geval is.

II3. Aansprakelijkheid is bovendien geen synoniem van schadeloosstelling, vermits de te bekomen vergoeding afhankelijk is van de solvabiliteit van de aansprakelijke. Waarom wordt dat insolvabiliteitsrisico niet, hetzij via een private, verplichte verzekering, hetzij via de sociale zekerheid, gecollectiviseerd?

Even moeilijk is te verteren dat het aansprakelijkheidsrecht (tenzij in geval van een wettelijke uitzondering) tot het wilsaanvullend recht wordt gerekend ongeacht het getroffen belang.

De daartoe aangevoerde redenen overtuigen niet. ${ }^{167}$ De lankmoedigheid waarmee bedrieglijk, lucratief en/of opzettelijk gedrag regelmatig wordt benaderd en daardoor overigens door de vingers wordt gezien, vergt eveneens grondige bijsturing.

II4. In het tweede deel van de twintigste eeuw heeft de rechtspraak van de overheidsaansprakelijkheid (wetgevende, uitvoerende en rechterlijke macht) een complex en allesomvattend bouwsel gemaakt.

Dat burgers en ondernemingen ook ten aanzien van de overheid bescherming behoeven en verdienen, staat buiten kijf, ook al wordt de aansprakelijkheidslast die op de overheid wordt gelegd (via de begrotingswetten), door de samenleving gedragen. Dat aspect wordt evenwel in het kader van de overheidsaansprakelijkheid niet in aanmerking genomen.

In een wereld waarin de overheid niet langer met de scepter zwaait, rijst de vraag of zulks wel verstandig is. De overheid is manifest geen rechtssubject zoals alle

I62 Bij toepassing van de splitsingsmethode vangt dat toekomstig luik met de beslissing van de feitenbeoordeler aan.

I63 O.m. L. Cornelis, 'Over samenloop, schade en overbodig causaal verband: roemloos aansprakelijkheidsrecht (partim)', TBH 2013, 998-1000.

I64 Naargelang de (ver)gissing tot een over- dan wel onderschatting leidt.

I65 Inspiratie is in de arbeidsongevallenwetgeving te vinden.

I66 De 'individuele vrijheid' van het slachtoffer steekt daar momenteel een stokje voor: o.m. D. de Callatay en N. Estienne, o.c., 57.

I67 Zie L. Cornelis, 'L'irresponsabilité', in F. Rozenberg (ed.), Les responsabilités en matière commerciale. Actualités et perspectives, Limal, Anthemis, 2014, 220-228. 
anderen: zij is immers de vertegenwoordiger van alle, tot de samenleving behorende rechtssubjecten.

Eerder vroeg dan te laat moet dat verschil in aanmerking worden genomen: een ad hoc aansprakelijkheidsrecht dat de overheidsmiddelen beschermt, is geen overbodige luxe.

II5. Het stelselmatig uitgebreide domein van de overheidsaansprakelijkheid staat bovendien in schril contrast met de vaststelling dat de aandeelhouders van ondernemingen in het aansprakelijkheidsrecht witte raven lijken te zijn.

Zij blijken van een aansprakelijkheidsimmuniteit te genieten.

De vaststelling is opmerkelijk: sinds meerdere tientallen jaren is niet langer de (onder een aanzienlijk aansprakelijkheidsrisico gebukt gaande) overheid de centrale figuur, waarrond de samenleving draait. Naar macht en invloed loopt de overheid meer en meer in de schaduw van het ondernemingsleven, de multinationale 'corporations' op kop.

Hoewel ondernemingen (en hun aandeelhouders) voluit genieten van alle door de overheid in het leven geroepen, georganiseerde, gehandhaafde en gefinancierde openbare diensten, ${ }^{168}$ eisen ze minder en minder overheidsinmenging en -controle. Wanneer hun omzet- en winstverwachtingen worden tegengewerkt, wanneer omzet- of winstallocaties door de overheid scheef worden bekeken, dreigen ze met de afbouw of stopzetting van hun activiteiten.

Fiscaliteit en arbeidsplaatsen worden door hen daarbij als koopwaar verhandeld: de overheid ondergaat de wet van de sterkste.

Moet op de aandeelhouders van de onderneming geen aansprakelijkheid rusten, zoals op alle andere rechtssubjecten - afgezien van de overheid?

II6. Op de onderneming en op haar bestuurders zijn aansprakelijkheidsrechtsregels toepasselijk. ${ }^{169}$

Ten aanzien van aandeelhouders van rechtspersonen met beperkte aansprakelijkheid wordt - zonder veel nadenken - aangenomen dat hun aansprakelijkheid tot hun inbreng en aldus tot de aansprakelijkheid van de onderneming beperkt is.

I68 Overigens zowel rechtstreeks als onrechtstreeks. Rechtstreeks wanneer zijzelf van die openbare diensten genieten; onrechtstreeks wanneer de personen die zij voor hun activiteiten inzetten (werknemers, lasthebbers, aangestelden, uitvoeringsagenten, enz.) van die openbare diensten genieten om de rechtspersonen (hun aandeelhouders) bij te staan; vgl. ook in die zin: M. Mazzucato, The entrepreneurial State. Debunking public vs. Private sector myths, Londen, Anthem Press, 20I4, 237 p.

I69 Voor een overzicht: J. Delvoie en A. François, 'Buitencontractuele aansprakelijkheid van rechtspersonen en hun bestuurders jegens derden', in Actuele ontwikkelingen inzake vennootschapsrecht, Antwerpen, Intersentia, 2010, 215-252; K. Byttebier en T. Wera, 'Aansprakelijkheid in de vennootschap', in Actueel aansprakelijkheidsrecht, Brussel, Larcier, 20I2, I76-2Io; P. De Wolf, 'La responsabilité civile (hors faillite) les dirigeants de sociétés commerciales. Principes et actualités', in F. Rozenberg (ed.), Les responsabilités en matière commerciale, Limal, Anthemis, 20I4, 7-3I. 
Gaat de onderneming, bij wijze van voorbeeld, op aansprakelijkheidsgronden overkop, dan gaat hun inbreng in rook op en daarmee zou het, wat hun aansprakelijkheid betreft, over en uit zijn.

Die immuniteit van de maatschappelijk sterksten, want dat zijn aandeelhouders in overgrote mate, mist elke grondslag.

Het zijn immers de aandeelhouders die, collectief, de handel en wandel van de onderneming via door hen aangestelde bestuurders bepalen. Die handel en wandel is aan elke aandeelhouder welbekend, vermits zijn/haar aandeelhouderschap erdoor wordt bepaald, ${ }^{170}$ en is hem/haar dan ook toerekenbaar.

Foutief ondernemings- dan wel bestuurdersgedrag wordt derhalve door de aandeelhouders mogelijk gemaakt, geduld en, onder omstandigheden, verwacht om op hun investering tot rendementen te komen, die zonder dat gedrag onbereikbaar zouden zijn.

Aandeelhouders die het met foutief ondernemingsgedrag oneens zijn, kunnen uitstappen en daartoe de gepaste initiatieven nemen.

Wanneer ze naar rendementen streven die manifest boven de jaarlijkse groei van het BNP liggen, weten of moeten ze weten dat daaraan foutief ondernemingsgedrag ten grondslag kan liggen.

Mikken op disproportioneel rendement, maar de ogen voor het onderliggende ondernemingsgedrag sluiten, doet of zijn neus bloedt, wat in het aansprakelijkheidsrecht tot de rode kaart leidt.

Kortom, ondernemings- dan wel bestuurdersaansprakelijkheid moet op aandeelhoudersniveau een staartje kunnen krijgen: aandeelhouders staan voor hun gedrag als aandeelhouder in, ook wanneer dat gedrag erop neerkomt dat zij anderen die foutief bezig zijn, laten betijen.

Door zich van ondernemingen/bestuurders te bedienen, handelt elke aandeelhouder zelf, dag in, dag uit.

Die handelingen zijn aan het aansprakelijkheidsrecht toetsbaar, zonder dat de omweg van handelingen die tijdens de algemene vergadering van aandeelhouders worden gesteld, nodig is.

De aansprakelijkheid van aandeelhouders is te beoordelen in functie van de feitelijke omstandigheden waarin zij zich bevinden. ${ }^{\mathrm{i7}}$ Controlerende aandeelhouders staan op de eerste rij, maar onder omstandigheden is volgens sommigen ook te rekenen met de aansprakelijkheid van minderheidsaandeelhouders die slechts voor hoge rendementen oog hebben, daaraan alles ondergeschikt achten en dus blindelings laten betijen. Het verschil tussen meerderheids- en minderheidsaandeelhouders kan trouwens ook in hun onderling verhaal worden verdisconteerd.

I70 Ontevredenheid over die handel en wandel leidt ertoe dat de aandeelhouder 'met de voeten stemt', het voor bekeken houdt en zijn/haar aandelen van de hand doet.

I7I Aandeelhouders die - al dan niet tegen vergoeding - stemmen ter beschikking stellen, dan wel ronselen om welbepaalde beslissingen op aandeelhoudersniveau door te drijven, moeten instaan voor het daarop gesteunde (gebeurlijk foutief) beleid van de vennootschap en/of haar bestuurders (zie m.b.t. die praktijk: C. Clottens, Proportionaliteit van stemrecht en risico in kapitaalvennootschappen, Antwerpen, Biblo, 2012, 394-469). 'Short selling' moet onder omstandigheden eveneens aan het aansprakelijkheidsrecht worden getoetst. 
f) Eenmaal de smaak te pakken...

II7. Voorgaande verder te onderzoeken voorbeelden kunnen met tal van andere worden aangevuld, ontleend aan het verbintenissen-, het contracten- en het aansprakelijkheidsrecht, al dan niet in samenhang met het vennootschaps-, het economisch of het financieel recht. Telkens duikt daarbij een belangeninversie op en zijn er remedies beschikbaar, die de inversie niet enkel tegengaan, maar ook de cohesie en de kenbaarheid van recht en van rechtsbedeling bevorderen.

Tot die aspecten behoren de neutralisering van bedrieglijk, lucratief en/of opzettelijk gedrag; de neutralisering van belangenvermengingen; ${ }^{172}$ de prijsregulering; het ingaan tegen benadelingen, enz.

In het algemeen zijn alle juridische technieken waardoor vermogenstransferten en vermogensaccumulatie worden nagestreefd of bevorderd, aan hernieuwd onderzoek toe.

Die voorbeelden bevestigen dat de instrumenten in het rechtsgebeuren beschikbaar zijn, waardoor wordt vermeden dat het eigenbelang het collectief belang, rechtstreeks of onrechtstreeks, in de vernieling fietst.

Die instrumenten liggen sinds lang op juristen te wachten, die de moed willen opbrengen om de finaliteit van recht en rechtsbedeling als openbare diensten te bestendigen, die de daarvan uitgaande boodschap weten uit te dragen en daarmee andere beleidsmakers aansporen om terug in te palmen wat zij al te licht uit handen hebben gegeven, de voorrang van het collectieve belang op het eigenbelang.

$\mathrm{Na}$ de (drie) onderzoeksvragen ${ }^{173}$ van antwoord te hebben gediend, wordt het tweede deel gewijd aan de wijze waarop rechtspraak en rechtsleer met de gepercipieerde complexiteit van het rechtsgebeuren omgaan.

Het zal geen verbazing wekken dat de resultaten daarvan, niet steeds in de richting van de in het eerste deel gewenste kentering gaan. De krachtmeting tussen collectief en eigenbelang is immers volop aan de gang.

\section{DEEL 2: De nering}

II8. In een Radio I interview beklemtoonde Van Orshoven dat een burger voor de rechtbank nooit mag zeggen dat hij de toepasselijke wet niet kende. ${ }^{174}$ Het staat inderdaad vast dat de onwetendheid of vergissing omtrent het bestaan, de toepasselijkheid of de draagwijdte van een rechtsregel niet volstaat om een tekortkoming aan een wettelijke of contractuele verplichting goed te praten. Dit belet evenwel niet dat het onder omstandigheden verontschuldigend of rechtvaardigend werkt dat een rechtsregel door een rechtsonderhorige niet gekend was of voor hem niet

I72 M. Kruithof, 'Wanneer vormen tegenstrijdige belangen een belangenconflict?', in Van alle markten, Liber amicorum Eddy Wymeersch, Antwerpen, Intersentia, 2008, 575-598; J. Moret-Bailly, Les conflits d'intérêts, Parijs, LGDJ, 20I4, 228 p.

I73 De drie onderzoeksvragen luiden, pro memorie, als volgt: (I) Waarom is het rechtsgebeuren complex?; (2) Is er sprake van toenemende complexiteit?; (3) Mits de toename wordt bevestigd, kan het privaatrecht daaraan iets veranderen?; zie hiervoor nr. I4.

I74 Zie www.radior.be/programmas/feiten-en-fillet/nemo-censetur-ignorare-legem. 
kenbaar was. Een algemene theorie rond die verontschuldigende of rechtvaardigende omstandigheden ontbreekt evenwel en zou zelfs niet mogelijk zijn. ${ }^{175}$ Alleen Van Gerven en Lierman durven een kernachtig geformuleerd criterium naar voren schuiven. Volgens hen is het criterium 'of de geadresseerde zelf dan wel via bemiddeling van een beroepsvereniging, juridisch raadgever, enz., de regel had kunnen, of moeten, kennen én begrijpen en, in geval van kennis via, of hij de middelen had om op bemiddeling een beroep te doen'. ${ }^{176}$ De vraag is evenwel of dit criterium door de rechtspraak wordt bevestigd en, zo ja, of de drempel dat een persoon een regel niet had moeten kennen en begrijpen, eerder hoog of eerder laag ligt en wanneer de inschakeling van een derde zoals een advocaat volstaat. Het mag al worden verklapt, de drempel blijkt eerder hoog te liggen. Om een concreet zicht op de relevante omstandigheden te krijgen, hebben de verslaggevers daarom de belangrijkste leerstukken geïdentificeerd waarin de rechtsdwaling een rol speelt (2.I), om vervolgens, over die leerstukken heen, na te gaan aan welke omstandigheden een min of meer belangrijke rol toekomt (2.2). Het opzet van dit alles is dan ook na te gaan in welke mate het (privaat)recht op de (toegenomen) rechtscomplexiteit inspeelt en de 'scheeftrekkingen' die door die rechtscomplexiteit ontstaan, probeert 'recht' te trekken.

\section{I Overzicht van de leerstukken}

IIg. De vergissing omtrent het recht komt in een reeks van leerstukken aan bod, die hierna kort worden besproken: het wilsgebrek van de verschoonbare rechtsdwaling, de onoverkomelijke rechtsdwaling als strafrechtelijke schulduitsluitingsgrond en als civielrechtelijke rechtvaardigingsgrond, de bescherming van het rechtmatig vertrouwen van de rechtsonderhorige tegenover de overheid, in het bijzonder in geschillen omtrent fiscale en socialezekerheidsschulden, de disculperende rechtsdwaling in het EU-recht, de geschillen waarin rechtsregels strijdig worden bevonden met het rechtszekerheids- of het legaliteitsbeginsel, de aansprakelijkheid van juridische adviseurs en andere beroepsbeoefenaars, de overheidsaansprakelijkheid en de voldoende gekwalificeerde schending in het EU-aansprakelijkheidsrecht.

\subsubsection{Verschoonbare rechtsdwaling}

I20. De rechtsdwaling heeft verschillende verschijningsvormen. Beoefenaars van het privaatrecht denken onmiddellijk aan de rechtsdwaling als wilsgebrek bij de totstandkoming van overeenkomsten. Ook al hebben contractpartijen overeenstemming bereikt over de door partijen te verrichten prestaties, een partij kan in bepaalde omstandigheden toch ontsnappen aan de overeenkomst doordat ze zich bij het sluiten van de overeenkomst over een essentieel aspect blijkt te hebben

I75 Volgens het preadvies van B. Bouckaert van een twintigtal jaar geleden zou niet zomaar een alomvattende theorie kunnen worden uitgebouwd ('Verdwaald in de jungle van de wet. Biedt rechtsdwaling een uitkomst?', TPR I993, I347-I407).

I76 W. Van Gerven en S. Lierman, Algemeen Deel. Veertig jaar later. Privaat- en publiekrecht in een meergelaagd kader van regelgeving, rechtsvorming en regeltoepassing, Mechelen, Kluwer, 2010, nr. 66, p. I80. 
vergist. Dat aspect kan het al dan niet van toepassing zijn van of de draagwijdte van een al dan niet toepasselijke rechtsregel, zo wordt intussen algemeen aanvaard.177 Het adagium Nemo censetur ignorare legem staat een rechtsdwaling niet in de weg. ${ }^{178}$ Het is evenzeer gemeengoed dat een rechtsdwaling alleen tot de nietigverklaring van een overeenkomst leidt als de (determinerende) vergissing verschoonbaar is.

Het verschoonbaarheidsvereiste ${ }^{\mathrm{I} 79}$ speelt een cruciale rol wanneer is te bepalen of een vergissing omtrent het recht met zich meebrengt dat een overeenkomst voor vernietiging vatbaar is. Rechtsdwaling mag dan wel in principe als wilsgebrek in aanmerking komen, in de praktijk wordt niet zo gemakkelijk tot de verschoonbaarheid ervan besloten, ${ }^{180}$ al zouden sommigen het meer opportuun en zowaar zelfs progressiever vinden dat de verschoonbaarheidsdrempel lager zou liggen. ${ }^{\text {I8r }}$

Een dwaling wordt verschoonbaar geacht als een redelijke persoon, in dezelfde omstandigheden geplaatst, dezelfde vergissing als de dwalende partij zou hebben begaan. Het is, aldus het Hof van Cassatie, niet noodzakelijk vast te stellen dat de vergissing 'door elke behoorlijk zorgvuldige persoon die hetzelfde beroep uitoefent,

I77 Onder meer W. Van Gerven m.m.v. S. Covemaeker, Verbintenissenrecht, Leuven, Acco, 20Io, p. I22; P. Van Ommeslaghe, Droit des obligations, I, Brussel, Bruylant, 20Io, p. 243, nr. I44; P. Wéry, Droit des obligations, I, Brussel, Larcier, 20I0, p. 2I6, nr. 232, met enkele andere verwijzingen.

I78 In die zin uitdrukkelijk Rb. Hasselt 2 april 200I, RW 2004-05, 75I (verschoonbare dwaling van de verkoper omtrent de stedenbouwkundige status van het verkochte onroerend goed, dat in werkelijkheid niet lag in bosgebied maar in woongebied met landelijk karakter (in tegenstelling tot de informatie afkomstig van de notaris).

I79 Het verschoonbaarheidsvereiste werd voor het eerst tot uitdrukking gebracht in Cass. 6 januari I944, Arr. Cass. 1944, 66, Pas. I944, I, I33, noot R.H. (Royale Belge vorderde de vernietiging van een overeenkomst omdat ze meende dat een ongeval een arbeidsongeval was. De feitenrechter overwoog evenwel dat de verzekeraar 'zoodanig door rechtsgeleerden bijgestaan was dat "zij niet onwetend heeft kunnen zijn" nopens de rechtspraak van het Hof van verbreking, die met die meening in strijd is' zodat geen sprake was van een onverschoonbare dwaling. Volgens het Hof van Cassatie is een dwaling onverschoonbaar als ze 'van zulken aard is dat een redelijk mensch ze niet begaat').

I80 Naast het geval in voetnoot 1003 vermeld, twee mooie gevallen waarin rechtsdwaling werd aanvaard: Gent 29 november I996, TGR I997, 64 (met betrekking tot een schuldbekentenis met hypothecaire volmacht die door de echtgenote van een oneerlijk zelfstandig bankagent ten gunste van de kredietinstelling was gedaan. De schuldbekentenis werd op basis van dwaling vernietigd, omdat de echtgenote zich had vergist over haar al dan niet gehoudenheid voor de schulden van haar echtgenoot en het statuut van het onroerend goed); het bioaminéegeval van Gent 9 januari 20I2, TBBR 20I4, I74, noot A. Maes, 'De dwaling in rechte: een nieuw paardenmiddel?' (met betrekking tot een contract van distributie van een bloedproduct dat hoofdzakelijk voor sportpaarden bestemd was maar waarvan achteraf is gebleken dat dit product toch niet aan die paarden mag worden toegediend omdat ze in de voedselketen terecht konden komen).

Voor een geval waarin de rechtsdwaling niet verschoonbaar was, zie Brussel 30 juni 20Io, TRV 20I0, 50I, noot C. Clottens (een leonijns beding in een verkoop van aandelen wordt voor niet geschreven gehouden, maar de vordering tot nietigverklaring van de ganse overeenkomst wordt afgewezen: 'dat in de gegeven omstandigheden de dwaling van geïntimeerde omtrent het verbod van artikel 32, tweede lid W.Venn. dat binnen het vennootschapsrecht een regel is die teruggaat tot de basis van het vennootschapscontract, niet verschoonbaar is'.

I8I Zie in die zin A. De Boeck, 'De wilsgebreken dwaling en bedrog vandaag. Responsabilisering en ankerplaats voor de precontractuele informatieverplichting', in R. Van Ransbeeck, Wilsgebreken, Brugge, die Keure, 2006, 56-57. De rechtspraak wordt streng bevonden door B. Bouckaert, o.c., I 378 . 
in dezelfde omstandigheden zou zijn begaan en dat het gedrag van de vergissende partij niet foutief was'. ${ }^{\text {I82 }}$

In de rechtsleer wordt getwist zowel over de grondslag van het verschoonbaarheidsvereiste, als over de aard van de toetsing van het gedrag aan dat van de redelijke persoon.

Wat de grondslag betreft, zou het verschoonbaarheidsvereiste volgens velen ${ }^{\mathrm{I} 83}$ een toepassing van de algemene zorgvuldigheidsnorm op grond van artikelen $1382-{ }_{3} 83$ van het Burgerlijk Wetboek (BW) zijn. Met andere woorden, een persoon die onverschoonbaar dwaalt, kan de vernietiging van de overeenkomst niet vragen omdat hij door zijn vergissing een fout heeft begaan. Die opvatting is evenwel niet verzoenbaar met de uitdrukkelijke overweging van het Hof van Cassatie dat geen fout in het gedrag van de vergissende partij moet worden vastgesteld om tot de onverschoonbaarheid van een dwaling te besluiten. Overigens is het verschoonbaarheidsvereiste in de cassatierechtspraak nooit met zoveel woorden aan de artikelen I3 $_{3}$ 2-I3 $_{3} 3 \mathrm{BW}$ gekoppeld, maar wel aan de bepalingen van het BW inzake het wilsgebrek dwaling. In de eerste plaats is het dus relevant of de wilsvorming van een partij al dan niet is aangetast. De wilstheorie is evenwel geen verklaring voor de verschoonbaarheidsvereiste. In de praktijk verwijst het verschoonbaarheidsvereiste ernaar dat de partij die zich vergist, in de concrete omstandigheden van de zaak gerechtigd was om af te gaan op het aspect waarop de vergissing betrekking heeft (rechtmatig vertrouwen). ${ }^{\mathrm{I}}{ }^{4}$

Naar de aard van de toetsing toe, komt in het kader van het rechtmatig vertrouwen meer ruimte vrij om rekening te houden niet alleen met de objectieve, maar ook de subjectieve omstandigheden van de zaak, zoals de kennis, de ervaring en mogelijk de middelen van zowel de dwalende partij, als van haar medecontractant. ${ }^{185}$

In het kader van de rechtsdwaling zou dit tot gevolg moeten hebben dat rekening wordt gehouden met het verschil in kennis van het recht en in sectorervaring van de betrokken contractpartijen. Dit komt trouwens in de rechtspraak tot uiting. Illustratief is de zaak waarbij een tandarts een gebouw verkocht aan een vastgoedontwikkelaar, die het gebouw wilde afbreken en door een appartementsgebouw wilde vervangen. Beide partijen wisten bij het sluiten van het contract niet dat de realisatie van dit project vrijwel onmogelijk was, doordat het gebouw in een lijst van bouwkundig erfgoed was opgenomen (informatie die wel publiek op het internet is te vinden,

I82 Zie het Rossignol-geval van Cass. 28 juni I996, AR C.95.or37.F, Arr. Cass 1996, 664, Pas. I996, I, 7I4 (verschoonbare rechtsdwaling van een verzekeraar bij het sluiten van een verzekeringsovereenkomst tot dekking van het risico op verduistering van gelden toevertrouwd aan een voogdadvocaat, van wie achteraf kwam vast te staan dat hij die hoedanigheden niet had).

I83 Zie recent nog A. Maes, 'De dwaling in rechte: een nieuw paardenmiddel?', TBBR 20I4, I76-I8I.

I84 Zie hierover A. De Boeck, 'De wilsgebreken dwaling en bedrog vandaag. Responsabilisering en bedrog vandaag. Responsabilisering en ankerplaats voor de precontractuele informatieverplichting', in R. Van Ransbeeck (ed.), Wilsgebreken, 2006, 56-57.

I85 In die zin zie het bijzonder goed gemotiveerde vonnis van Rb. Hasselt 2 april 200I, RW 2004-05, 75I: de vraag naar de verschoonbaarheid van een dwaling is geen toepassing van de precontractuele aansprakelijkheid, maar impliceert een vergelijking met een 'redelijk en voorzichtig persoon, geplaatst in dezelfde objectieve én subjectieve omstandigheden' (in casu hoefde de verkoper de van een professionele derde (notaris) verkregen informatie niet alsnog te hebben geverifieerd). 
maar niet aan de eigenaar individueel ter kennis wordt gebracht). De koper-vastgoedontwikkelaar vorderde vervolgens de vernietiging van de koop wegens dwaling. ${ }^{86}$ De rechtbank hield rekening met de sectorervaring van beide partijen. De tandarts-verkoper is weliswaar een professioneel, maar is beroepshalve niet met vastgoed maar met tanden bezig. In het licht van de beroepsbezigheden van beide partijen werd de vordering van de koper-vastgoedontwikkelaar tot nietigverklaring van de verkoop wegens dwaling afgewezen, omdat zijn vergissing niet verschoonbaar was. Vooraleer een contract te sluiten, had hij kunnen verifiëren welke juridische beperkingen zijn project konden dwarsbomen, wat hij klaarblijkelijk nagelaten had te doen. ${ }^{187}$

\subsubsection{Onoverkomelijke dwaling als strafrechtelijke schulduitsluitingsgrond}

I2I. In het strafrecht wordt sinds de Tweede Wereldoorlog aanvaard dat een rechtsdwaling het bestaan van een misdrijf (en bijgevolg de strafbaarheid ervan) uitsluit. ${ }^{188}$ Ook al staan de materiële bestanddelen van een misdrijf vast, toch kan een beklaagde zich met succes verweren door zijn vergissing in te roepen mits zijn dwaling onoverkomelijk is. ${ }^{189}$ Uit de concrete omstandigheden moet kunnen worden afgeleid dat ieder bedachtzaam en voorzichtig mens die in dezelfde toestand verkeert, zoals de verdachte zou hebben gehandeld. ${ }^{\text {190 }}$

Hoewel een deel van de strafrechtelijke rechtspraak soms tegelijk van een verschoonbare en onoverkomelijke dwaling spreekt alsof het om synoniemen zou gaan, ${ }^{191}$ stelt de onoverkomelijkheid toch - zo wordt aangenomen - strengere eisen aan de rechtsdwaling in het strafrecht dan aan de verschoonbaarheid die in het kader van het wilsgebrek dwaling wordt beoordeeld. ${ }^{192}$ De onoverkomelijkheid wordt voorgesteld als een 'stringente voorwaarde', ${ }^{193}$ ze zou de lat hoger leggen dan

I86 Die dwaling zou van feitelijke aard (over het al dan niet opgenomen zijn van het onroerend goed op de lijst van bouwkundig erfgoed) of van juridische aard (over het bestaan van de regeling inzake de lijsten van bouwkundig erfgoed) kunnen zijn.

I87 Zie Rb. Gent Io januari 20I2, TBBR 20I3, 390, noot J. Callebaut, 'Substantiële voorwaarden bij het bod tot aankoop van onroerend goed: quo vadis?'

I88 Cass. ro juli 1946, Pas. I946, I, 293.

I89 Er is geen uitdrukkelijke wetsbepaling in die zin, maar de schulduitsluitingsgrond wordt aan art. 7I SW. gekoppeld (en in het civiele recht aan artikelen II47-II48 BW).

I90 Cass. 3I oktober 1994, RW I994-95, II22, Arr. Cass. 1994, 898, noot J.F.L.; Cass. I8 januari I999, RCJB 2000, 725, noot F. Glansdorff; Cass. I6 januari 200I, Arr. Cass. 200I, 88 (schending verkeersreglement).

I9I Zie bijvoorbeeld in Cass. Io april I975, Arr. Cass. I975, 87I met betrekking tot het wilsgebrek dwaling (Freddy-case).

I92 Zie F. Glansdorff, 'Erreur invincible ou croyance légitime' (noot onder Cass. I8 januari I999), RCJB 2000, p. 736, nr. I5 ('une erreur excusable n'est pas nécessairement invincible'); B. Goffaux, o.c., 370 ('l'invincibilité doit être appréciée plus sévèrement que l'excusabilité); ook reeds M. Coipel, 'L'erreur de droit inexcusable' (noot onder Cass. Io april I975), RCJB I978, p. 2II, nr. Io.

I93 B. De Smet, 'De onoverkomelijke rechtsdwaling als wapen tegen overregulering en artificiële incriminaties', RW I992-93, I29I. 
bij de verschoonbaarheid het geval is, waarmee een 'wijde kloof' bestaat, ${ }^{194}$ en de kans zou 'eerder gering' zijn dat een rechtsdwaling onoverkomelijk wordt geacht. ${ }^{195}$

De feitenrechter komt inderdaad niet licht tot het besluit dat een rechtsdwaling onoverkomelijk is. ${ }^{196}$ Ook het Hof van Cassatie houdt de vinger op de knip en laat

I94 B. Bouckaert, o.c., p. I382, nr. I5.

I95 I. Verhaert en P. Waeterinckx, 'Strafrechtelijke verantwoordelijkheid, een beheersbare ondernemingsrisico? De delegatie in strafrecht', RW 200I-02, I009.

Gevallen waarin de rechtsdwaling niet onoverkomelijk werd geacht: Corr. Dendermonde I6 januari 2009, T Milieurecht 2009, 300 (in een brochure was duidelijk vermeld dat het gebruik van de palingfuik verboden is; 'de beklaagden dienden geacht te worden de op hun activiteiten toepasselijke regelgeving te kennen'); Luik 7 januari 2009 (samenvatting door B. Jadot), Amén. 2009, 2I6 (strafrechtelijke veroordeling wegens het achterlaten van afvalstoffen - 'Le prévenu invoque à tort la complexité de la législation alors qu'il argumente depuis des années au sujet de la notion de déchet'); Antwerpen 8 oktober 2008, T Milieurecht 20I0, 407 (discussie in de schoot van stedelijke bestuursorganen over de goedkeuring van een BPA en aldus omtrent de bestemming van een hoeve brengt geen onoverwinnelijke rechtsdwaling met zich mee; 'als professionele aannemer wist dat zij over een stedenbouwkundige vergunning moest beschikken alvorens tot slopen over te gaan'); Corr. Turnhout 4 februari 2003, T Milieurecht 2003, 502 (ooievaars gehouden met opengezaagde ring: 'dient beklaagde, als uitbater van een kinderboerderij, zijnde een lucratieve bezigheid, meer nog dan de modale burger de betreffende wetgeving te respecteren en zich desgevallend te informeren omtrent de vigerende richtlijnen'); Antwerpen 27 juni 200I, TMR 200I, 284 (geweigerde bouw- en milieuvergunning - na beroep bouwvergunning wel verleend - beroep was beperkt tot de weigering van de bouwvergunning - 'thans niet kan voorgehouden worden dat het beroep ook betrekking had op de weigering van de exploitatievergunning' - evenmin veronderstelling dat de beroepsbeslissing op beide vergunningen betrekking had 'gelet op de duidelijke bewoordingen vervat in het Ministerieel Besluit waaromtrent geen vergissing mogelijk is'); Hoei 2I april I998, RRD 200I, II5 (boom omgehakt door landbouwers die zeiden dat ze de toepasselijke wettekst niet kenden: 'que cette justification ne prouve pas la bonne foi, d'autant plus que les prévenus exercent la profession d'agriculteur, profession particulièrement réglementée par de nombreuses dispositions auxquelles les agriculteurs doivent se soumettre'); Rb. Brussel 31 oktober 1995, Rev.dr.pén. I996, 232 ('que le simple fait que des fonctionnaires de police ne constatent pas une infraction, à supposer que cette dernière ait pu l'être aisément, ne permet pas de se prévaloir d'une erreur invincible'); Antwerpen 6 januari I984, Pas. I984, II, 85 (fiscale aanslag op spelen). Zie ook Cass. I6 mei I995, Arr. Cass. I995, 48I (verwerpingsarrest - veranda zonder bouwvergunning - beklaagde kon terecht bij architect voor inlichtingen); Corr. Brugge 8 november I984, RW I985-86, I229, noot P. Arnou (aardnootgeval - twee testen op aflatoxine onvoldoende want in casu geen veiligheidsmarge).

I96 Voorbeelden waarin een onoverkomelijke dwaling werd aanvaard: Bergen 20 mei I987, JT I987, 501 (contactlenzen door opticien zonder voorafgaand medisch onderzoek - rechtsdwaling aanvaard in het licht van de onduidelijk omschreven bevoegdheid: 'la délimitation des compétences de l'opticien n'ayant pas été légalement définie avec une précision suffisante contrairement à ce qui fut fait pour d'autres professions'); Brussel 7 maart I990, JLMB I990, 674 (minister van Binnenlandse Zaken bevraagd door parlementslid had geantwoord dat er geen verplichting is om de gemeentelijke politie aan een periodiek medisch onderzoek te onderwerpen - 'que cette opinion est l'illustration des interprétations erronées qui ont existé en la matière et dont l'absence de poursuites judiciaires contre d'autres bourgmestres placés dans la même situation que le prévenu paraît être une illustration supplémentaire'); Corr. Brussel 28 december I989, JT I990, 330 (laksheid in controle van slachterijen - 'une cause subjective de justification' gelet op de dagelijkse controle door experten van het departement volksgezondheid - 'qu'il est patent que dans le laxisme qui présidait aux contrôles vétérinaires durant la période infractionnelle le prévenu a pu légitimement croire - comme l'aurait fait toute personne raisonnable et prudente - que ces pratiques quotidiennes dans l'abattage n'étaient pas répréhensibles' 'que s'il a été jugé qu'une tolérance administrative résultant d'une circulaire ministérielle comme telle dépourvue de tout effet juridique pouvait induire le justiciable en erreur, à plus forte raison faut-il admettre, qu'un contrôle quotidien par des experts vétérinaires a pu faire naître dans le chef du prévenu la conviction que ses actes ne violaient pas la loi'); Brussel 26 april 2000, JT 200I, 267 (bouwvergunning vernietigd door de Raad van State - misdrijf vanaf kennisgeving van nietig- 
niet veel ruimte voor de feitelijke vaststelling van een onoverkomelijke dwaling door een strikt te noemen controle op het begrip 'onoverkomelijke rechtsdwaling', dan wel op de juridische deductie van een onoverkomelijke rechtsdwaling uit de concrete feiten in een bepaald geschil (zie verder paragraaf ${ }_{13}$ 6). ${ }^{197}$ Van Den Bon omschrijft de houding van de Belgische rechtspraak ten aanzien van de onoverkomelijke dwaling als volgt:

'Onwetendheid kan echter niet volstaan als vrijbrief, zelfs wanneer die wordt gekoppeld aan de sociale en economische zwakheid van de burger die van sociale uitkeringen geniet en niet over de vereiste intellectuele bagage en logistieke steun beschikt om op de hoogte te zijn van de ingewikkelde reglementeringen. Met andere woorden het volstaat niet dat men niet weet, maar vereist wordt dat, wat men weet, verkeerd heeft begrepen door omstandigheden die het verkeerd begrip onoverkomelijk hebben gemaakt.' ${ }^{\prime 19}$

Vanuit de complexiteit van het recht wordt de strengheid van die rechtspraak wel eens op de korrel genomen. Zo schreef Rozie onlangs:

'De rechtzoekende die wil uitzoeken wat al dan niet strafbaar is, moet nu niet alleen meer uitzoeken wat er in de strafwet staat, maar ook wat de jurisprudentiële stand van zaken is met alle mogelijke gevolgen van dien. Zelfs een normaal voorzichtige, redelijke en voorbereide rechtzoekende kan dus eigenlijk niet altijd meer voorspellen of een bepaalde gedraging strafbaar is. ${ }^{199}$

Er kan dan ook niet worden voorbijgegaan aan een recent arrest van 28 maart 2012 (het loodsarrest), ${ }^{200}$ waarin het Hof van Cassatie een beslissing vernietigde waarbij de feitenrechter geen onoverkomelijke dwaling had aanvaard ten aanzien van de persoon die werd vervolgd wegens het optrekken en instandhouden van een loods zonder stedenbouwkundige vergunning. De vergunning was wel verleend maar werd naderhand onwettig verklaard omdat de gemachtigde ambtenaar ten onrechte niet was geraadpleegd vooraleer de vergunning werd verleend en de vergunning bovendien strijdig was met een gemeentelijk stedenbouwkundig reglement (inzake de materialen voor buitenbekleding en dakbedekking). De volgende, door het Hof samengevatte, overwegingen verantwoorden de beslissing niet naar recht, aldus het Hof van Cassatie:

verklaringsarrest - voordien onoverkomelijke dwaling gelet op positief advies van gemachtigd ambtenaar en ondanks hoedanigheid van gemeenteraadslid en aannemer gelet op gebrek aan bijzondere kennis terzake). Zie ook Cass. 24 mei 2002, AR F.or.0o65.F (ontvankelijkheid van bezwaar in fiscale zaak wegens onoverkomelijke dwaling door toedoen van overheid die meer behelsde dan verkeerde informatie).

I97 Zie Cass. I5 november I988, Pas. I989, I, 276 (videocassettegeval); Cass. I oktober 2002, T.Gez. 2004-05, I3I, noot T. Balthazar, 'Het gedeeld beroepsgeheim is geen uitgesmeerd beroepsgeheim'; Cass. 29 mei 2002, Arr. Cass. 2002, I375.

I98 P. Van Den Bon, noot onder Antwerpen 9 oktober 1997, Soc. Kron. I998, I47.

I99 J. Rozie, 'Beklaagde Alwetend. Over het criterium van de redelijke voorzienbaarheid als maatstaf van het lex certa-principe in strafzaken', RW 20I2-13, p. 803, nr. 2.

200 Cass. 28 maart 20I2, AR P.II.2083.F. 
‘...) de eiser, die een gepensioneerd aannemer van openbare werken is, onmogelijk niet op de hoogte kon zijn zowel van de decretale voorschriften betreffende de verplichting voor de administratie om het advies van de gemachtigd ambtenaar in te winnen, als van de regels die in een landbouwzone toepasselijk zijn op de bouw. Het arrest wijst er eveneens op dat de eiser geen plan van een architect heeft ingediend tot staving van zijn vergunningsaanvraag, zodat de door bij hem ingezette procedure van bij de aanvang gebrekkig was, en dat hij dit diende te weten'.

Vervolgens geeft het Hof van Cassatie in de verklarende kernoverwegingen aan waarom het tot dit besluit is gekomen:

'Het verlenen van een vergunning nadat de raadplegingsprocedure en het stedenbouwkundig reglement zijn nageleefd, behoort tot de bevoegdheid van de administratie, zodat de houder van de vergunning niet verantwoordelijk kan worden gesteld voor de fouten die zij heeft begaan.

Artikel 159 Grondwet heeft geen gevolgen voor het antwoord op de vraag of de dwaling die door de onwettige administratieve akte is veroorzaakt onoverkomelijk was.

Het vermoeden dat de wet gekend is, wettigt de bewering niet dat elke normaal redelijke en voorzichtige persoon de onwettigheden van de vergunning die aan de administratie te wijten zijn, zou hebben opgemerkt.

Het arrest stelt niet vast dat de akte dermate onregelmatig was dat de eiser ze redelijkerwijs als onbestaand had moeten beschouwen.'

Het gebeurt niet elke dag dat het Hof van Cassatie een beslissing vernietigt omdat de feitenrechter een dwaling niet als onoverkomelijk beschouwde. Meestal gebeurt het omgekeerde, namelijk dat een feitenrechter beslist dat een dwaling wel onoverkomelijk is en het Hof van Cassatie die beslissing vervolgens vernietigt.

De overweging dat de overheidshandeling zo onregelmatig moet zijn dat de rechtsonderhorige ze redelijkerwijs als onbestaand had moeten beschouwen, staat ver van de vereiste dat elke redelijke persoon dezelfde dwaling zou hebben begaan. Het Hof overweegt overigens dat de dwaling een rechtvaardigingsgrond is 'als ieder redelijke en voorzichtig persoon die dwaling had kunnen begaan indien hij in dezelfde situatie zou hebben verkeerd als die waarin de beklaagde zich bevond' (met eigen cursivering). Dit staat dan weer in contrast met de overweging in een eerder vernietigingsarrest van het Hof van Cassatie van 22 februari 2010 (zij het in een socialezekerheidsgeschil en in het kader van het overmachtsbegrip) '[d]at het arrest dat de dwaling die elke redelijke en voorzichtige persoon in dezelfde omstandigheden had kunnen begaan als overmacht beschouwt en niet de dwaling die een dergelijke persoon in dezelfde omstandigheden had begaan, miskent het wettelijk begrip overmacht' (met eigen cursivering). ${ }^{201}$ Wellicht is de strafrechtelijke context een belangrijke factor waarom het Hof van Cassatie in het loodsarrest van 28 maart

201 Cass. 22 februari 20Io, AR S.09.0044.F (derde kamer). De vergelijking tussen die twee arresten werd reeds gemaakt door J. Van Zuylen, 'Du fait justificatif à la force majeure: les visages contrastés de l'exonération de la responsabilité', in X, Evaluation du dommage, responsabilité civile et assurances: Liber Amicorum Noël Simar, Limal Anthemis, 2013, p. 29I-292, nr. 27. 
2012 zich inschikkelijker jegens de dwalende rechtsonderhorige toont dan in het socialezekerheidsarrest van 22 februari 2010.

\subsubsection{Onoverkomelijke dwaling als civielrechtelijke rechtvaardigingsgrond}

I22. Een onoverkomelijke rechtsdwaling ${ }^{202}$ rechtvaardigt niet alleen in het strafrecht, maar ook in het civiel (aansprakelijkheids)recht een schending van de wet. Buiten het kader van een schending van een welbepaald wettelijk gebod of verbod, kan een onoverkomelijke rechtsdwaling daarnaast ook in aanmerking worden genomen om de zorgvuldigheid van bepaald gedrag in het licht van een ingeroepen buitencontractuele of de contractuele aansprakelijkheid te beoordelen. ${ }^{203}$

Opdat een rechtsdwaling rechtvaardigend zou werken, moeten twee voorwaarden vervuld zijn: niet alleen moet de vergissing het gevolg zijn van een vreemde oorzaak die niet aan de dwalende persoon kan worden toegerekend, maar er moet ook kunnen worden vastgesteld dat ze door elke voorzichtige en redelijke persoon in dezelfde omstandigheden zou zijn begaan. ${ }^{204}$ In de gevallen dat er van een vreemde oorzaak sprake zou zijn (zoals de complexiteit van wetgeving), blijft meestal het verwijt over dat de rechtsonderhorige zich niet afdoende heeft geïnformeerd. ${ }^{205}$

Van de onoverkomelijke rechtsdwaling zijn in de gepubliceerde rechtspraak weinig toepassingen te vinden. ${ }^{206}$ Volgens Bouckaert staat de uitslag immers 'quasi bij voorbaat' vast en gaat het slechts om een theoretische mogelijkheid in het burgerlijke aansprakelijkheidsrecht. ${ }^{207}$ Anderen zien daarbij in de toegepaste standaard eerder die van een superman dan die van de normaal zorgvuldige en omzichtige persoon. ${ }^{208}$

Niettemin is er toch op enige toepassingen te wijzen. Het bekendste geval is dat van de geneesheer-specialist voor wie geen aansprakelijkheid van het ziekenhuis werd aangenomen nadat hij het testament van een patiënte (die amper vijf uren na haar opname overleed) had neergepend; dit testament was dus niet geldig tot stand

202 Vroeger sprak men eerder van een 'onoverwinnelijke' dwaling. Het is een algemeen rechtsbeginsel dat dwaling een rechtvaardigingsgrond is wanneer ze onoverkomelijk is (zie Cass. 25 oktober 1999, S.98.0II2.N).

203 B. Bouckaert, o.c., p. $1_{3} 63$, nr. 7.

204 Onder meer B. Bouckaert, o.c., p. 138I, nr. 15. Zie ook Brussel 8 april 1992, T.Aann. 1998, I56 (overheidsopdrachten): 'un obstacle insurmontable à la réalisation de l'obligation, sans qu'une faute puisse être imputée au débiteur'.

205 B. Bouckaert, o.c., p. I383, nr. I5: 'Voorbeelden van dergelijke oorzaken zijn: de complexiteit van de wetgeving, het gedogen door de overheid, het verkeerd advies. Inzake complexiteit van de wetgeving lijkt de rechter weinig medeleven te betonen met de slachtoffers der "legislomanie" (...) In de meeste gevallen wordt dit weggewimpeld met het argument dat men zich beter had moeten informeren.'

206 Zo schrijft ook herhaaldelijk T. Léonard, 'Faute extra-contractuelle et juridictions commerciales: principes et plaidoyer pour un retour à une vision unitaire de la faute', TBH 2013, p. 966968, nrs. I6-I8.

207 Zie B. Bouckaert, o.c., p. I36r, nr. 6 en p. I363, nr. 7.

208 Zie B. Goffaux, 'L'erreur invincible en matière civile', TBBR 2013, 374 ('homme idéal, en tout point irréprochable'). 
gekomen omdat het, in strijd met artikel $970 \mathrm{BW}$, niet geheel door de testator met de hand was geschreven. ${ }^{209}$

De plaats van de onoverkomelijke dwaling als rechtvaardigingsgrond werd onlangs ter discussie gesteld. Ten aanzien van inbreuken op wetten die onduidelijk zijn, wordt gesuggereerd om aan de rechtsdwaling in verhoudingen tussen rechtsonderhorigen helemaal geen plaats te geven, maar alleen in een verhouding van een rechtsonderhorige tegenover de overheid, omdat rechtsdwaling rechtsonzekerheid tot gevolg heeft voor de 'partij die wel haar vertrouwen stelde op de gewraakte regelgeving. ${ }^{210}$ Het Hof van Cassatie heeft zich zelfs ook in een rechtsverhouding tegenover de overheid terzake bijzonder streng getoond. Zo vernietigde het Hof een arrest waarin een laattijdig bezwaar van een belastingplichtige niettemin ontvankelijk werd verklaard omdat die was voortgegaan op de door de fiscus aangeduide (verkeerde) begindatum voor de termijn voor het indienen van een bezwaar. ${ }^{21}$

\subsubsection{Bescherming van het rechtmatig vertrouwen tegenover de overheid bij fiscale en socialezekerheidsschulden}

I23. In de Belgische context beroept de rechtsonderhorige zich geregeld op rechtmatig vertrouwen in de verhouding met de overheid, wanneer zij een socialezekerheidsuitkering terugvordert of een bijkomende betaling in het kader van fiscale wetgeving vordert, bijvoorbeeld omdat een btw-aftrek onrechtmatig is gebeurd of ten onrechte geen btw aan een afnemer van een goed of dienst is aangerekend.

Hoewel het Hof van Cassatie, in het bijzonder door een veel besproken arrest van 27 maart $1992,{ }^{212}$ ruimte liet voor de toepassing van het vertrouwensbeginsel in fiscale zaken, zelfs wanneer de verwachtingen van de belastingplichtige op een onwettige praktijk berustten, heeft het Hof daarvan vervolgens afstand genomen in een bij fiscalisten berucht arrest van I5 februari $2013{ }^{213}$ nadat het daarmee al

209 Rb. Leuven 5 oktober I994, RW I994-95, I06I, noot T. Hens. Zie ook andere gevallen waarin geen onoverkomelijke dwaling werd aanvaard: Cass. 25 oktober I999, AR S.98.oII2.N (vordering van RSZ wegens hoofdelijke aansprakelijkheid van opdrachtgever voor socialezekerheidsbijdragen van aannemer die via geschriften de opdrachtgever in de waan liet dat hij nog geregistreerd was); Cass. I4 mei 20I2, AR S.II.oor.F - S.II.or27.N, conclusie M. Palumbo (vernietigingsarrest m.b.t. vakantiegeld verschuldigd bij overgang van contractuele naar statutaire regeling - onduidelijkheid van regeling en gezond verstand onvoldoende om tot onoverkomelijke dwaling te besluiten); Brussel 8 april I992, T. Aann. 1998, I56 (aansprakelijkheidsvordering wegens miskenning van een overheidsopdrachtenregel - de VZW die de regel had miskend, kon het reglement hebben onderzocht); Luik 6 april 2000, JT 200I, 27I (cinemazaalarrest - vordering van gehandicapten wegens ontoegankelijkheid - fout van exploitant, vastgoedpromotor, Waals Gewest en gemeente); Brussel I oktober 2003, JT 2004, 698 (studieprefectgeval - het bestaan van een eerder arrest van de Raad van State belet rechtvaardiging - voorziening verworpen bij Cass. I6 september 2005, AR C.04.0276.F)

2 Io Zie B. Van den Bergh, “"Recht zkt zekerheid” voor vaste relatie', RW 20I0-II, 358, voetnoot 78.

2 II Cass. I8 januari I999, RCJB 2000, 725, noot F. Glansdorff, 'Erreur invincible ou croyance légitime'.

2 I2 Cass. 27 maart I992, AR 689I, Arr. Cass. I992, 727.

$2 \mathrm{I} 3$ Cass. I5 februari 20I3, AFT 20I3, 65. Zie onder meer L. Vandenberghe, 'Rechtmatig vertrouwen in actieve vergissingen van de administratie: begaat het Hof van Cassatie een actieve vergissing, met miskenning van de Europese btw- en douanerechtspraak?', TFR 20I4, 278-297. 
eerder $^{214}$ geleidelijk restrictiever omging, wat sommigen ${ }^{215}$ toen reeds als te restrictief omschreven.

In het socialezekerheidsrecht werpt een ontvanger van een onverschuldigde betaling wel eens op dat hij/zij in zijn/haar gerechtvaardigde verwachtingen zou worden beschaamd indien het betaalde bedrag zou moeten worden terugbetaald. ${ }^{216}$ Volgens de rechtspraak van het Hof van Cassatie is evenwel aan die terugvordering niet te ontkomen op grond van de bescherming van gerechtvaardigd vertrouwen, omdat een afwijking van de wet daardoor niet wordt gerechtvaardigd. ${ }^{217}$ Dat is ook het geval als de betaler een zelfs onverschoonbare vergissing heeft begaan, ${ }^{218}$ tenzij de wetgever van die regel is afgeweken. ${ }^{219}$

Procureur-Generaal Leclercq verwoordde de redenering kernachtig als volgt:

'Het wettelijkheidsbeginsel kan nooit worden geweerd omdat het rechtstreeks gegrond is op een Grondwettekst, namelijk artikel 159 van de Grondwet [...] Ongetwijfeld kan de voorrang van het wettelijkheidsbeginsel, ook al is hij in rechte juist, onaangename gevolgen hebben vanuit het oogpunt van de billijkheid. De rechtzoekende tegen wie het wettelijkheidsbeginsel wordt aangevoerd

2 I4 Cass. 3 november 2000, AR F.98.0072.N: 'het recht op rechtszekerheid van een individuele belastingplichtige geen onbeperkt recht is en onder omstandigheden moet wijken voor het legaliteitsbeginsel van artikel to van de Grondwet dat de rechtszekerheid en gelijkheid verzekert ten bate van alle belastingplichtigen'. Zie ook in de context van stedenbouwkundige vergunningen, Cass. I maart 20I0, AR C.09.0390.N, CDPK 20II, I, conclusie adv.-gen. Mortier, noot R. Valkeneers, 'Een nieuw, maar toch vertrouwd geluid bij cassatie? Belangenafweging en de contra legem werking van algemene rechtsbeginselen' (Mortier: 'Ook het legaliteitsbeginsel heeft een relatieve waarde en moet worden afgewogen tegen de toepassing van andere beginselen. Het gegeven dat het Grondwettelijk verankerd is toont het grote belang van dit beginsel aan maar doet geen afbreuk aan het relatief karakter ervan').

2 I5 V. Dauginet en B. Ameye, 'Rechtszekerheid, vertrouwensbeginsel en goede trouw. Europeesrechtelijke doorwerking in de Belgische rechtsorde', AFT 2009, 3-38.

2I6 Zie bijvoorbeeld Arbrb. Hassselt 9 mei I995, JT r996, 2 Io.

217 Cass. II februari 20II, AR F.og.or6I.N ('De verwachtingen van de burger mogen evenwel niet gegrond zijn op een onwettelijke praktijk'); Cass. 29 november 2004, AR S.03.0057.F (vernietigingsarrest); Cass. I6 december 2002, Soc. Kron. 2004, 2002, noot D. Torfs, 'Is terugvordering van kinderbijslag mogelijk wanneer het kinderbijslagfonds een fout heeft gemaakt bij de toekenning van de kinderbijslag?'. In het vernietigingsarrest van 26 mei 2003 (A.R. nr. S.or.oro8.F, RW 200405, noot V. Sagaert, 'Onverschuldigde betaling en het rechtmatig vertrouwen van de accipiens', JLMB 2006, I87, noot P. Kallai, 'La répétition de l'indu et l'assuré social de bonne foi') besliste het Hof van Cassatie dat "de leer van de "eerbiediging van de gewettigde verwachtingen van een ander"' niet tot gevolg kan hebben dat de Kas voor Kinderbijslag afstand zou moeten doen van haar eis tot terugbetaling van een onverschuldigd betaalde verhoogde kinderbijslag voor gehandicapte kinderen.

2 I8 Cass. I december I989, RW I989-90, I356: 'dat de omstandigheid dat de dwaling van eiseres onverschoonbaar was, niet tot gevolg heeft dat een van de bestanddelen van de onverschuldigde betaling ontbreekt'.

2I9 Wat bijvoorbeeld is gebeurd in artikel I7, lid 2 van de wet van II april I995 tot invoering van het Handvest van de sociaal verzekerde (lid $\mathrm{I}$ : 'Wanneer vastgesteld wordt dat de beslissing aangetast is door een juridische of materiële vergissing, neemt de instelling van sociale zekerheid op eigen initiatief een nieuwe beslissing die uitwerking heeft op de datum waarop de verbeterde beslissing had moeten ingaan, onverminderd de wettelijke en reglementaire bepalingen inzake verjaring.' - lid 2: 'Onverminderd de toepassing van artikel I8, heeft de nieuwe beslissing, indien de vergissing aan de instelling van sociale zekerheid te wijten is, uitwerking op de eerste dag van de maand na de kennisgeving ervan, als het recht op de prestatie kleiner is dan het aanvankelijk toegekende recht.'). 
kan nochtans altijd pogen het te omzeilen [sic] door zich te beroepen op het gemeen recht van de burgerrechtelijke aansprakelijkheid. ${ }^{220}$

Het vertrouwensbeginsel kon de vordering tot terugbetaling van een onverschuldigde betaling aldus niet neutraliseren, maar Leclercq laat wel ruimte voor een schadevergoedingsvordering op grond van buitencontractuele foutaansprakelijkheid: ${ }^{221}$ 'L'application du principe de légalité au profit de l'Office national de sécurité sociale ne fait pas obstacle, en cas de négligence de sa part en raison des circonstances de la cause, à la condamnation de celui-ci à payer des dommages et intérêts à l'employeur.'222

Het is begrijpelijk dat de rechtspraak in deze materie terughoudend is om gevolgen aan het ingeroepen rechtmatig vertrouwen van de rechtsonderhorige toe te kennen. Volgens sommige auteurs is die rechtspraak echter beleidsmatig voor kritiek vatbaar omdat ze 'een vrijgeleide aan de overheid [geeft] om de lasten van complexe wetgeving naar burgers te verschuiven, die de belangrijkste verantwoordelijkheid krijgen om die wetgeving te doorgronden'. ${ }^{23}$ Vanuit juridisch-technisch oogpunt plaatsen ze vraagtekens bij het ondergeschikt maken van het vertrouwensbeginsel (als deel van het rechtszekerheidsbeginsel) aan het zogenoemde wettelijkheidsbeginsel (als Grondwettelijk beginsel op grond waarvan de wetgever de belangrijkste parameters voor het ontstaan van fiscale schulden moet bepalen). Ze zetten daarbij in de verf dat het vertrouwensbeginsel evenzeer grondwettelijk van aard is en zowel een beginsel van Unierecht is dat door het Hof van Justitie is erkend, als een algemeen beginsel van behoorlijke wetgeving in de interne rechtsorde, dat door het Grondwettelijk Hof is erkend. Volgens hen kan bijgevolg niet zomaar worden beweerd dat het rechtszekerheidsbeginsel in de normenhiërarchie lager zou staan

220 J.F. Leclercq, conclusie onder Cass. 26 mei 2003, AR S.or.oro8.F.

22I Uit de cassatierechtspraak blijkt dat feitenrechters de schade soms begroten op het bedrag van de terugbetaling, zodat de verrekening op een nulsaldo neerkomt. Zo besliste het Arbeidshof te Luik in het geval dat leidde tot het cassatiearrest van 25 november 2002, AR S.00.0036.F (een geval van onterechte toekenning van verlaging van werkgeversbijdragen): 'Dat bijgevolg de meest geëigende vergoeding in een vorm van kwijtschelding van schuld schijnt te bestaan waarbij de R.S.Z. zou worden veroordeeld tot de betaling van een schadeloosstelling tot beloop van een bedrag, gelijk aan het oorspronkelijk door hem gevorderde bedrag'. Dat blijkt ook uit het geval dat leidde tot een cassatiearrest van 22 mei 2006 (verwerpingsarrest; CDPK, 2008, 456, noot S. Koval, 'Après le temps de l'apparence: considérations sur la confiance légitime du citoyen et la responsabilité de l'administration dans la jurisprudence de la Cour de cassation'). Het ging om een geval waarin de administratie zeven jaren had gewacht alvorens een situatie te herzien en de gedane gezinsuitkeringen terug te vorderen (een arts had in I986 aangeduid dat de gezondheidssituatie van het kind moest worden geherevalueerd, maar het kwam toe aan de administratie om de herevaluatie op te starten, wat pas in 1993 gebeurde). In dat arrest werd de schade begroot op het bedrag van de te veel gedane uitkeringen, waarna verrekening volgde. Van dat cassatiearrest van 22 mei 2006 is vooral de overweging van belang dat de feitenrechter 'justifie légalement sa décision que le dommage résultant de cette faute est équivalent au montant des allocations familiales indûment majorées'. Het Hof van Cassatie lijkt terzake een vrij grote beoordelingsvrijheid toe te kennen aan de feitenrechter.

222 J.F. Leclercq, conclusie onder Cass. 25 november 2002, AR S.00.0036.F, met verdere verwijzing naar conclusies bij Cass. 6 november 2000, A.R. 99.oIo8.F.

223 Aldus P. Popelier, 'Het vertrouwensbeginsel versus het legaliteitsbeginsel: het kalf is verdronken, maar wanneer dempt men de put?', AFT 2013, p. 53, nr. 4. 
dan het wettelijkheidsbeginsel en niet contra legem zou kunnen werken. ${ }^{24}$ Het blijft evenwel zo dat zij die de toepassing van het vertrouwensbeginsel bepleiten en er inhoud proberen aan te geven, blijven erkennen dat de uitkomst van de toepassing ervan steeds onzeker blijft, ${ }^{225}$ wat haaks staat op het rechtszekerheidsbeginsel waarvan het vertrouwensbeginsel als een exponent wordt beschouwd.

\subsubsection{Disculperende rechtsdwaling in het EU-recht}

I24. In het recht van de Europese Unie (EU) komt regelmatig en in verschillende contexten aan bod of een rechtsdwaling als excuus kan gelden ten aanzien van een schending van een EU-regeling, om aldus aan de toepassing van die regeling te ontsnappen.

In het mededingingsrecht werd door Advocaat-Generaal Kokott voor het volgende principe gepleit:

'Uit het beginsel nulla poena sine culpa volgt dat een onderneming voor een schending van de mededingingsregels waaraan zij zich puur objectief gezien schuldig heeft gemaakt, slechts ter verantwoording kan worden geroepen als deze schending haar ook in subjectief opzicht valt te verwijten. Heeft de onderneming daarentegen verontschuldigbaar gedwaald omtrent de onrechtmatigheid van haar gedrag, dan kan niet worden vastgesteld dat zij een inbreuk heeft begaan en kunnen haar ook geen sanctie, zoals bijvoorbeeld geldboeten, worden opgelegd.".26

De Advocaat-Generaal voegde er wel onmiddellijk aan toe dat ondernemingen 'slechts zeer zelden' aan de semistrafrechtelijke sancties voor mededingingsinbreuken zullen kunnen ontkomen: 'Dit zou alleen het geval zijn als de betrokken onderneming al het redelijk mogelijke heeft gedaan om de haar ten laste gelegde inbreuk op de mededingingsregels van de Unie te vermijden. ${ }^{227}$ Zoals verder wordt toegelicht (paragraaf 136 ), is het Hof van Justitie evenwel minder ver gegaan: terwijl het aannam dat de onderneming alleen kan worden aangesproken als het niet onkundig kan zijn van het mededingingsverstorende karakter van haar gedrag, laat het alleen ruimte voor een bescherming van het gewettigd vertrouwen van een onderneming, indien een bevoegde overheidsinstantie haar een concrete toezegging heeft gedaan. ${ }^{228}$

De rechtsdwaling komt in de arresten van het Hof van Justitie (en het Gerecht) vooral aan bod in het kader van navorderingen van douanerechten, die krachtens de wet verschuldigd zijn. In het Communautair Douanewetboek is het

224 Zie L. Vandenberghe, o.c., p. 288, nr. 36: 'de toepassing van het vertrouwensbeginsel is als het ware onvermijdelijk "contra legem"'.

225 Zie aldus N.A. De Vos, 'Het vertrouwensbeginsel in rechtsvergelijkend perspectief met inbegrip van het Europese vertrouwensbeginsel', CDPK 2012, p. 536, nr. I ('een belangenafweging impliceert waarvan het resultaat moeilijk te voorspellen is').

226 J. Kokott, conclusie van 28 februari 2013 in de zaak Schenker, C-68I/II, ov. 44.

227 J. Kokott, conclusie van 28 februari 2013 in de zaak Schenker, C-68I/II, ov. 46.

228 HvJ I8 juni 20I3, nr. C-68I/II, Schenker, ov. 37-43 (arrest in Grote Kamer geveld). 
vertrouwensbeginsel wettelijk verankerd. ${ }^{229}$ De toets daarbij bestaat erin te weten of de marktdeelnemer de vergissing kan ontdekken, waarbij telkens rekening wordt gehouden met (I) de aard van de vergissing, (2) de beroepservaring van de marktdeelnemer en (3) de door deze betrachte zorgvuldigheid. Met het criterium van de aard van de vergissing wordt vooral gepeild naar het eenvoudige, dan wel ingewikkelde karakter van de relevante wettelijke rechtsregel. Wat de beroepservaring betreft, wordt nagegaan of de activiteiten van de onderneming voornamelijk in- en uitvoer betreffen en of zij reeds met de invoer van de litigieuze goederen enige ervaring heeft opgedaan. Het criterium van de betrachte zorgvuldigheid is erop gericht te weten of de marktdeelnemer de relevante regels (beter) had moeten bestuderen, wat zeker het geval is als de marktdeelnemer twijfels had of moest hebben. ${ }^{230}$ Aldus hebben het Gerecht en het Hof van Justitie beoordelingsfactoren aangereikt om een rechtsdwaling al dan niet in aanmerking te nemen, ofschoon de vaststelling of het vertrouwen van een marktdeelnemer al dan niet bescherming verdient, aan de nationale rechter toekomt.

Rechtsdwaling kan soms ook worden ingeroepen door personen die van de financiële steun van een lidstaat (staatssteun) of van een EU-instelling (subsidies) hebben kunnen genieten, terwijl die steun onrechtmatig werd toegekend. Opnieuw is het niet verrassend te noemen dat de gevolgen van een onrechtmatigheid slechts in uitzonderlijke omstandigheden kunnen worden gehandhaafd en dus, in de regel, niet ongedaan worden gemaakt omwille van het rechtmatig vertrouwen van de marktdeelnemer.

Het Hof is aldus bijzonder streng ten aanzien van de verplichting tot voorafgaande melding van staatssteun. Een gewettigd vertrouwen in de vermeende rechtmatigheid van staatsteun kan in beginsel slechts bestaan als die steun door de steunverlenende Staat aan de Commissie vooraf is gemeld: 'Een behoedzame ondernemer zal immers normaliter in staat zijn, zich ervan te vergewissen of deze procedure is gevolgd. ${ }^{231}$ Afgezien daarvan laat het Hof van Justitie wel toe dat de ontvanger van onwettig toegekende steun in 'uitzonderlijke omstandigheden' vertrouwen in de rechtmatigheid van de steun mag hebben. ${ }^{232}$

Met betrekking tot de financiële steun die een lidstaat krachtens een verkeerd uitgelegde regel van Unierecht toekent, is aldus met het rechtszekerheidsbeginsel naast het zogenoemde wettigheidsbeginsel te rekenen, zodat de begunstigde van de financiële steun de intrekking van de toekenningsbeslissing en de terugvordering

229 Artikel 239 van de toenmalige Verordening 2913/92 van I2 oktober I992 tot vaststelling van het communautair douanewetboek volgens hetwelk geen sprake mag zijn van kennelijke nalatigheid voor een terugbetaling of kwijtschelding (zie intussen art. 79 en 83-85 van de Verordening 450/2008 van 23 april 2008 tot vaststelling van het communautair douanewetboek (gemoderniseerd douanewetboek).

230 Zie onder meer Gerecht 5 juni 1996, nr. C-75/95, Günzler Aluminium/Commissie; HvJ 26 juni I990, nr. C-64/89, Deutsche Fernsprecher; HvJ 20 november 2008, nr. C-38/07P, Heuschen \& Schrouff; HvJ I2 december i996, nr. C-47/95 e.a., Olasagasti.

23I Zie HvJ 20 maart I997, nr. C-24/95, Alcan, ov. 25; HvJ 20 september I99o, nr. C-5/89, Commissie/ Duitsland, ov. I4.

232 Zie HvJ 20 september I990, nr. C-5/89, Commissie/Duitsland, ov. I6. Voor voorbeelden van dergelijke omstandigheden (zoals bij een precieze toezegging), zie C. Quigley, European State Aid Law and Policy, Oxford, Hart Publishing, 2009, p. 4I9 e.v. 
van de steun kan aanvechten mits hij/zij met betrekking tot de rechtmatigheid te goeder trouw was. ${ }^{233}$

\subsubsection{Rechtsregels in strijd bevonden met het rechtszekerheids- of legaliteitsbeginsel}

I25. In strijd met de bewering dat het 'legaliteitsbeginsel' in de normenhiërarchie boven het rechtszekerheidsbeginsel (waartoe ook het vertrouwensbeginsel behoort) zou staan, wordt nu en dan, zij het uitzonderlijk, een rechtsregel met het rechtszekerheidsbeginsel strijdig bevonden omdat die rechtsregel onvoldoende duidelijk of nauwkeurig is zodat rechtsonderhorigen hun gedrag op die rechtsregel niet op voorhand kunnen afstemmen. ${ }^{234}$ Voorbeelden daarvan zijn in de rechtspraak van het Grondwettelijk Hof, het Hof van Justitie en het EHRM aan te treffen.

Dat debat wordt bemoeilijkt door de overlapping die bestaat tussen het legaliteitsbeginsel, met de actueel daaraan toegekende betekenis, en het rechtszekerheidsbeginsel. Het legaliteitsbeginsel was traditioneel een beginsel met betrekking tot de bevoegdheidsverdeling tussen staatsmachten, aangevend wat aan de wetgever is voorbehouden. Geleidelijk aan kreeg het door de rechtspraak van het EHRM een andere lading waardoor inhoudelijke kwaliteitscriteria van de wetgeving, waaronder de voorzienbaarheid, op de voorgrond kwamen. Daardoor is een overlapping met het rechtszekerheidsbeginsel ontstaan. Volgens dit laatste beginsel moet de wet immers duidelijk zijn. ${ }^{235}$

Volgens een arrest van het Grondwettelijk Hof mag de toepassing van de wet (het ging over een inkomstenbelasting) niet op onevenredige wijze afbreuk doen aan het beginsel dat 'iedere belastingplichtige met een minimaal niveau van voorzienbaarheid het belastingstelsel moet kunnen bepalen dat op hem zal worden toegepast'. In casu werd een ongrondwettigheid vastgesteld in de mate dat de belastingwet aldus zou worden geïnterpreteerd dat de eigenaar van een verhuurd onroerend goed niet op het kadastraal inkomen, maar op de werkelijke huurprijs en -voordelen zou worden belast, wanneer de administratie de huurgelden heeft afgetrokken van de beroepsinkomsten van de huurder die zijn inkomsten uit een onwettige activiteit niet had aangegeven. Daardoor zou de eigenaar retroactief op de huurprijs- en voordelen zijn belast. ${ }^{236}$

In de rechtspraak van het Hof van Justitie werd een Belgische fiscale wet in verband met aftrekbaarheid van beroepskosten, in het licht van het vrij verkeer van diensten, strijdig bevonden met 'de vereisten van de rechtszekerheid, die verlangt dat rechtsregels duidelijk en nauwkeurig zijn en de gevolgen ervan voorzienbaar zijn, met name wanneer zij nadelige gevolgen kunnen hebben voor particulieren en

233 Zie HvJ 2I juni 2007, nr. C-I58/06, Stichting ROM-projecten, ov. 3I.

234 Omtrent de variërende draagwijdte van het rechtszekerheidsbeginsel, zie P. Popelier, Rechtszekerheid als beginsel voor behoorlijke regelgeving, Antwerpen, Intersentia, 1997, 663 p. Voor een synthese, zie W. Van Gerven en S. Lierman, o.c., nr. 65 e.v., p. 175 e.v.

235 T. De Clerck, 'Taal: de rechtsonzekerheid van het fiscaal recht', TFR 20I2, 955.

236 GWH 27 mei 2008, nr. 86/2008, ov. B.9.I-B.9.2. 
ondernemingen, zodat de beperking van het vrij verkeer van diensten niet gerechtvaardigd is want niet evenredig met de nagestreefde doelstellingen'.237

Bij de omzetting van richtlijnen moeten lidstaten er eveneens rekening mee houden 'dat een onduidelijke wetgeving die de betrokken rechtssubjecten in onzekerheid laat over hun mogelijkheden om zich op het gemeenschapsrecht te beroepen, niet voldoet aan de verplichting om de richtlijn in nationaal recht om te zetten'. ${ }^{238}$

Het rechtszekerheidsbeginsel geldt ook voor rechtsregels van het Unierecht en vereist dat een regeling van de Unie 'de belanghebbenden met name in staat stelt de omvang van de verplichtingen die zij hun oplegt, nauwkeurig te kennen. De justitiabelen moeten immers ondubbelzinnig hun rechten en verplichtingen kunnen kennen en dienovereenkomstig hun voorzieningen kunnen treffen'. ${ }^{239}$

In de rechtspraak van het EHRM dienden Oekraïense (andermaal fiscale) rechtsregels tweemaal als schietschijf voor het 'principle of lawfulness'. In de 'Shchokin'zaak kwam het Hof tot het besluit dat de aangevochten fiscale wet onvoldoende duidelijk en precies was met uiteenlopende interpretaties over een belangrijk fiscaal probleem als gevolg, zodat de vereiste 'quality of law' niet voorhanden was en die wet bijgevolg geen adequate bescherming bood tegen willekeurige inmenging door de overheid in de eigendomsrechten van de verzoeker. ${ }^{240}$

In de 'Serkov'-zaak werd een Oekraïense fiscale wet strijdig bevonden met het eigendomsrecht, beschermd door artikel I van het Eerste Protocol bij het EVRM, omdat het hoogste Oekraïense gerechtshof zonder verdere uitleg zijn eerdere rechtspraak had gewijzigd. Het EHRM overwoog dat het geen rechtvaardiging voor de wijziging in de wetsinterpretatie vond, waarmee de verzoeker werd geconfronteerd. Het wees er in het bijzonder op dat het hoogste gerechtshof de herinterpretatie niet had uitgelegd, wijzend op een gebrek aan transparantie, waardoor het vertrouwen van het publiek in het recht werd ondermijnd. De 'rule of law' werd aldus niet gerespecteerd. ${ }^{24 \mathrm{I}}$

De draagwijdte van die rechtspraak, hoe belangrijk ook, mag niet worden overdreven. De voorzienbaarheid van een rechtsregel laat de noodzaak onverlet dat een rechtsregel door de Hoven en Rechtbanken wordt geïnterpreteerd, ${ }^{242}$ wat door het EHRM treffend als volgt werd verwoord:

237 HvJ 5 juli 20I2, nr. C-3I8/Io, SIAT, ov. 58 (zie ook ov. 27: 'Bijgevolg is de werkingssfeer van deze bijzondere regel vooraf niet met voldoende nauwkeurigheid vastgesteld, zodat wanneer de dienstverrichter in een andere lidstaat dan het Koninkrijk België is gevestigd en daar aan een gunstigere belastingregeling is onderworpen dan die waaraan die inkomsten in België zijn onderworpen, er onzekerheid bestaat over de vraag of deze regeling zal worden beschouwd als een "aanzienlijk gunstigere regeling" en of de bijzondere regel dus zal gelden').

238 HvJ 3 maart I988, nr. II6/86, Commissie/Italië, ov. 2 I.

239 HvJ Io maart 2009, nr. C-345/o6, Heinrich, ov. 44 (geheim gehouden bepalingen inzake veiligheid luchtvaart), met verwijzing naar HvJ 2 I juni 2007, nr. C-I58/06, ROM-projecten, ov. 25). Zie ook HvJ 29 maart 20II, nr. C-20I/ogP en nr. C-2I6/ogP, ArcelorMittal, ov. 68.

240 Zie EHRM I4 oktober 20Io, Shchokin/Ukraïne, ov. 5I e.v.

24I EHRM 7 juli 2oII, Serkov/Ukraïne, ov. 40.

242 Zie bijvoorbeeld P. De Hert, 'De "kenbaarheid" van het strafrecht, babyvoeding en rechtsdwaling naar aanleiding van de (nieuwe) geneesmiddelenwet', AJT 1998-99, 680 ('op voorwaarde dat deze ontwikkeling coherent blijft met de wezensbestanddelen van het misdrijf en redelijk voorspelbaar is'). 
'The scope of the concept of foreseeability depends on a considerable degree on the content of the instrument in issue, the field it is designed to cover and the number and status of those to whom it is addressed. The mere fact that a legal provision is capable of more than one construction does not mean that it fails to meet the requirement of "foreseeability" for the purposes of the Convention. The role of adjudication vested in the courts is precisely to dissipate such interpretational doubts as remain, taking into account the changes in everyday practice. The task of the supreme courts in securing a uniform and coherent application of the law cannot be underestimated in this regard. A failure by a supreme court to cope with that task may produce consequences incompatible, inter alia, with the requirements of Article 1 of Protocol No. 1.243

Het rechtszekerheidsbeginsel verklaart die stemmen die ervoor pleiten om de werking in de tijd van onverwachte rechtspraak te beperken. ${ }^{244}$ In geval van een ommekeer van rechtspraak is rekening te houden met het feit dat de rechtsonderhorige rechtmatig op de eerdere rechtspraak kon vertrouwen, zodat rechters met omzichtigheid een overgangsrechtelijke regel zouden moeten kunnen voorzien: 'Het moet immers gaan om een onmiskenbare wijziging van de rechtspraak, die bovendien ook niet voorspelbaar was en waardoor het vertrouwen van de rechtzoekenden in het gedrang komt', aldus Dirix. ${ }^{245}$

\subsubsection{Aansprakelijkheid van juridische adviseurs en andere beroepsbeoefenaars}

I26. Van beroepsbeoefenaars en van juridische adviseurs in het bijzonder kan meer kennis van het recht en ervaring met de werking van het rechtsgebeuren worden verwacht dan van een leek. Dit geldt voor magistraten, advocaten, notarissen, gerechtsdeurwaarders, bedrijfsjuristen, enz.

Van personen die in een welbepaalde sector advies geven zonder doorgedreven juridische opleiding te hebben genoten, wordt ook verwacht dat ze over de juridische kennis beschikken die in die sector relevant is. Daarbij is te denken is aan bedrijfsrevisoren, accountants, belastingconsulenten, boekhouders, verzekeraars, bankiers, verzekerings- en vastgoedmakelaars, enz. Zo wordt, op straffe van precontractuele aansprakelijkheid, van een verzekeraar en een verzekeringsmakelaar verwacht dat zij de kandidaat-verzekeringsnemer informeren over een rijbewijsvereiste als ze een verzekeringsvoorstel ontvangen waarin de rubriek rijbewijs door de verzekeringsnemer niet is ingevuld. ${ }^{246}$

In het bijzonder ten aanzien van advocaten en notarissen is herhaaldelijk bevestigd dat hun raadgevingsverbintenis geen resultaats- maar een inspanningsverbintenis is. ${ }^{247}$ De feitelijke omstandigheden spelen daarbij een rol, zoals de snelheid

243 EHRM 7 juli 20II, Serkov/Ukraïne, ov. 35.

244 Zie onder meer E. Dirix, 'Rechterlijk overgangsrecht', RW 2008-o9, I754-I76o.

245 E. Dirix, o.c., p. I760, nr. Io.

246 Rb. Brugge I5 januari 2004, RW 2007-08, I255 (quad-geval).

247 Zie bv. Gent 17 oktober 20I3, AR 20I0/AR/3284 (advocaat); T. Van Sinay, 'Schiet (niet) op de pianist. Enkele bedenkingen over notariële aansprakelijkheid en mogelijke lacunes in informatieverschaffing omtrent onroerende goederen', TBBR 2003, 963 . 
waarmee een advies (bijvoorbeeld telefonisch) wordt verwacht, ${ }^{24}$ het al dan niet beslecht zijn van een juridisch vraagstuk in de rechtspraak, ${ }^{249}$ het bestaan van een controverse in rechtspraak of rechtsleer, ${ }^{250} \mathrm{en}$, in beperktere mate, de specifieke bekwaamheid of ervaring van de cliënt. ${ }^{251}$

Daarbij wordt beklemtoond dat de adviseur de plicht heeft om de cliënt in te lichten over onduidelijke wetgeving en te waarschuwen als er een controverse in rechtsleer of rechtspraak bestaat. ${ }^{252}$ Wel zou hij niet aansprakelijk zijn voor een meegedeelde persoonlijke voorkeur ten opzichte van een stelling in rechtsleer of rechtspraak. ${ }^{253}$ In situaties van onzekerheid kan en mag immers geen volledige zekerheid worden gegeven. ${ }^{254}$

Indien de jurist tot wie de leek zich wendt, onvoldoende kaas heeft gegeten van de materie waarover advies wordt gevraagd, moet hij, volgens meerdere auteurs, naar specialisten doorverwijzen. ${ }^{255}$ Die opvatting verdient nuancering, zoniet wordt de juridische markt te smal en zou de kostprijs van juridische adviesverlening al te duur worden, onder meer voor de minstbedeelden in de samenleving. Een jurist moet zich overigens dagelijks in nieuwe rechtsvragen kunnen inwerken en hij wordt opgeleid (of zou dat toch moeten zijn) om dergelijke nieuwe vragen aan te kunnen. Wel kan er van hem worden verwacht dat hij niet-juridische aspecten aan technische deskundigen overlaat, desgevallend in een interdisciplinair kader. Depuydt is wellicht in die zin te begrijpen wanneer hij schrijft: 'Mijns inziens is het "specialist" zijn juridisch niet relevant bij de beoordeling van het gedrag: wie de behandeling van een dossier aanvaardt, moet in de betrokken materie kunnen handelen als een "specialist"; acht een advocaat zich daartoe niet in staat, dan doet hij er goed aan de zaak te weigeren. ${ }^{256}$

248 Zie R. Devloo, 'De aansprakelijkheid van de accountant en de belastingconsulent - Nieuwe aspecten', De Belg. Acc. I999, afl. 4, p. 6. Maar zie Brussel 27 januari 2009, T.Not. 2009, 536, noot L. Weyts ('Ten onrechte beroept Z. zich op de haast waarmee hij heeft moeten werken [...]. Dat alles ontslaat hem niet van zijn verplichting om partijen in te lichten over de actueel geldende wetgeving.').

249 Zie R.O. Dalcq, 'Responsabilité notariale. Examen de jurisprudence', Rev. Prat. Not. I956, I48 (aansprakelijkheid in geval van een vergissing 'sur une question résolue par une jurisprudence constante').

250 Zie A.-L. Verbeke, 'Rechtszekerheid en aansprakelijkheid in het familiaal vermogensrecht', RW 20I0-II, I657-I660 (minderheidsopvatting onder aandacht van cliënt te brengen en risico's van die opvatting niet te overschatten of verabsoluteren).

25I Zie R. Devloo, o.c., 6; Bergen 24 januari 2002, JLMB 2003, I67I. Vergelijk J.-L. Rens, 'Overzicht aansprakelijkheid - Professionele aansprakelijkheid van de notaris (I973-2006)', TPR 2006, (I793) I82I, nr. 37.

252 Zie ook verder paragraaf 127 inzake de informatieplicht van de overheid, waarmee al eerder een analogie werd gemaakt in J. Stassen, noot onder Cass. 4 januari I973, RCJB I974, 350.

253 Ten aanzien van de notaris aldus $\mathrm{K}$. Troch, 'De notariële informatie- en raadgevingsverplichting revisited', TBBR I999, 297-298; T. Van Sinay, o.c., p. 695 (inlichtingsplicht).

254 Vgl. A.-L. Verbeke, o.c., I658.

255 A.-L. Verbeke, o.c., I66o ('men mag wel verwachten dat hij weet wanneer hij dat niet kan en dat hij zich dan wendt tot specialisten met wie hij samenwerkt').

256 P. Depuydt, 'De aansprakelijkheid van de advocaat. Bespreking van enkele grensdomeinen', in H. Vandenberghe (ed.), De professionele aansprakelijkheid, Brugge, die Keure, 2004, I3I. Vergelijk Antwerpen 28 september 2009, RW 20I2-I3, 257, noot B. Van den Bergh, 'Bezint eer ge begint? Over de professionele aansprakelijkheid van een advocaat wegens een gestrande actio mandati' (criterium van de 'normaal zorgvuldig en omzichtig advocaat (de goede huisvader)'. 
In de rechtsliteratuur omtrent de rechtsdwaling, die al dan niet als een vernietigingsgrond of als een schulduitsluitingsgrond wordt behandeld, wordt soms opgemerkt dat de leek zich in een dergelijke situatie tegen zijn adviseur met een aansprakelijkheidsvordering kan keren. Ook die overweging verdient nuancering, niet alleen omdat een aansprakelijkheidsvordering met tal van alea's gepaard gaat, ${ }^{257}$ maar vooral omdat de risico's verbonden aan de onzekerheden van een rechtsregel en de interpretatie slechts op de adviseur wegen als hij/zij een fout begaat.

\subsubsection{Aansprakelijkheid van de overheid}

I27. In bepaalde omstandigheden kunnen de gevolgen van een vergissing begaan door een rechtsonderhorige, via de buitencontractuele foutaansprakelijkheid op de schouders van de overheid worden gelegd. Er wordt immers aangenomen dat de overheid zoals elke andere rechtsonderhorige aan het aansprakelijkheidsrecht is onderworpen. Dit geldt voor de drie staatsmachten, inclusief, in principe, de wetgevende macht. ${ }^{25} \mathrm{Bij}$ de uitoefening van elk overheidsgezag moet niet alleen elk toepasselijk bepaald gebod of verbod worden nageleefd, maar moet ook worden gehandeld zoals een normaal zorgvuldige overheid in dezelfde concrete omstandigheden zou doen.

Veel aandacht ging naar de situatie, waarin een rechtsonderhorige op verkeerde inlichtingen van de overheid voortgaat en zich daardoor over de toepasselijke rechtsregel vergist. Volgens een princiepsarrest van 4 januari $1973^{259}$ is een vergissing door de bevoegde overheid in de beoordeling van de draagwijdte van de rechten van de rechtsonderhorige (in casu pensioenrechten) op zichzelf geen fout, maar wel indien een verkeerde uitlegging wordt gegeven 'zonder voldoende onderzoek of zonder de onzekerheid van de vermelde oplossing te laten blijken'. ${ }^{260}$ Uit de vaststelling door de feitenrechter dat een situatie in feite en in rechte ingewikkeld is, volgt niet dat voldoende onderzoek is verricht of dat de aandacht van de rechtsonderhorige op de twistpunten werd gevestigd. ${ }^{26 \mathrm{r}}$

Die rechtspraak betekent geenszins dat de rechtsonderhorige in alle omstandigheden op de inlichtingen, verstrekt door de overheid, kan voortgaan, zonder dat

257 Zie de voorzichtige formulering in B. Bouckaert, o.c., p. I386, nr. I6: 'Indien de rechtsbedeling inzake beroepsaansprakelijkheid keurig verloopt, is vermelde rechtspraak inzake de vernietiging van overeenkomsten van de leek niet per se onrechtvaardig'.

258 Cass. I juni 2006, AR C.05.0494.N, conclusie proc.-gen. De Swaef; Cass. 28 september 2006, AR C.02.0570.F.

259 Cass. 4 januari 1973, JT 1973, 550, noot J.L. Fagnart, RCJB 1974, 350, noot J. Stassen.

260 Voor twee toepassingen: Arbrb. Brugge I6 mei I997, AJT I998-99, 344, noot P. Popelier, 'De toepassing van het rechtszekerheids- en vertrouwensbeginsel en de aansprakelijkheid van de overheid voor foutieve informatie'; Rb. Luik 2I januari I986, JLMB I987, 385 .

Herhaaldelijk wordt beweerd dat op de overheid met betrekking tot verstrekte informatie geen resultaatsverbintenis, maar een inspanningsverbintenis rust. De toepassing van dit contractueel begrippenapparaat wordt terecht bekritiseerd door T. Léonard, o.c., p. 969-97I, nr. 2 I.

26I Zie voor een toepassing Arbrb. Brugge i6 mei I997, AJT I998-99, 344, noot P. Popelier, 'De toepassing van het rechtszekerheids- en vertrouwensbeginsel en de aansprakelijkheid van de overheid voor foutieve informatie'. 
bijkomend onderzoek door de rechtsonderhorige van de ontvangen informatie zou zijn te verwachten.

I28. Die rechtspraak met betrekking tot verkeerde informatie verstrekt door de overheid, is niet zomaar te transplanteren op gevallen waarbij de overheid een beslissingsbevoegdheid uitoefent, zo wordt herhaaldelijk beklemtoond.

Wanneer de uitvoerende macht een (individuele of algemene) publieke rechtshandeling stelt, dan zou die rechtshandeling aan de hogere rechtsnormen, inclusief de algemene beginselen van behoorlijk bestuur, moeten voldoen, zonder dat die uitvoerende overheid zich erop kan beroepen zich te hebben vergist over de draagwijdte van de hogere rechtsnorm, zelfs als ze aantoont voldoende onderzoek te hebben verricht of ze de rechtsonderhorige op mogelijke twistpunten met betrekking tot de interpretatie van de hogere rechtsnorm heeft gewezen. Een schending van een welbepaald gebod of verbod is immers op zich een fout, behoudens wanneer de overheid zich op een rechtvaardigingsgrond kan beroepen, zo luidt het. ${ }^{262}$

$\mathrm{Er}$ is evenwel niet zomaar te besluiten dat elke wettelijke rechtsregel een welbepaald gebod of verbod zou omvatten, laat staan dat elke schending van een wettelijke rechtsregel een fout zou zijn. Een schending van een wettelijke rechtsregel is op zich niet als een fout te beschouwen indien die wettelijke rechtsregel geen welbepaald gebod of verbod (gedrag) met zich meebrengt ${ }^{26_{3}}$ en indien een rechtvaardigingsgrond, in het bijzonder een onoverwinnelijke rechtsdwaling, voorligt, ${ }^{264}$ waarbij de complexiteit van de toepasselijke rechtsregel(s) telkens een rol kan spelen.

Het debat omtrent de vraag wanneer sprake is van een wettelijke rechtsregel met een welbepaald gebod of verbod, lijkt merkwaardigerwijs slechts recent op toerental te komen naar aanleiding van de mogelijke aansprakelijkheid van de Staat voor een

262 Cass. 4 november I982, RW I984-85, kol. 2083 (vernietigingsarrest). Zie recent nogmaals Cass. ro april 20I4, AR C.II.0796.N (termijn van orde).

263 In die zin het RSZ-geval van Cass. 25 oktober 2004, AR S.03.0072.F, met andersluidende conclusie J.-F. Leclercq; Cass. 23 juni 2005, AR C.04.0I6o.F (gebrek aan ontzegeling tot beslissing in casstie); Cass. 2I december 2007, AR C.o6.0457.F (beslag op gesmokkelde vrachtwagen); Cass. 8 februari 2008, AR C.07.013I.F (OCMW-secretaris).

264 Voor een streng voorbeeld, zie Cass. 23 september 20I0, JT 20II, 380, noot D. Renders, 'Erreur de droit invincible et état du droit incertain: à propos de la responsabilité civile de l'administration': in dat geval achtte het Hof van Cassatie het terecht dat niet tot het bestaan van een rechtvaardigingsgrond werd besloten in het geval waarbij een bestuur dat een goed had onteigend, naderhand had beslist het goed niet voor het algemeen belang in te zetten en het opnieuw te koop te stellen zonder de onteigende daarvan individueel op de hoogte te brengen. Voortgaand op een arrest van het Hof van Cassatie van I4 oktober 1948 volgens hetwelk uitdrukkelijk geen individuele kennisgeving vereist was, had het bestuur de beslissing enkel geafficheerd. In dat geval mocht de feitenrechter besluiten dat het bestuur daarvan, ondanks dat cassatiearrest, evenwel niet mocht uitgaan, gelet op het administratiefrechtelijk beginsel dat een administratieve handeling die rechten of plichten kan meebrengen voor een rechtsonderhorige, aan deze individueel ter kennis moet worden gebracht.

Wel onoverkomelijke dwaling aanvaard in Cass. 23 juni 2005, AR C.04.oroo.F (controverse over de interpretatie van een wetsbepaling inzake ruimtelijke ordening, beslecht in een arrest van Hof van Cassatie; gebrek aan ontzegeling niet foutief tot bekendmaking van de beslissing in cassatie - verwerpingsarrest); Cass. 8 februari 2008, AR C.07.0I3I.F (OCMW-secretaris - verwerpingsarrest). 
fout van de wetgevende macht. Het Hof van Cassatie besliste namelijk, terecht, dat de prejudiciële vaststelling door het Grondwettelijk Hof van de ongrondwettigheid (meer bepaald strijdigheid met het gelijkheidsbeginsel) van een bepaalde wet niet noodzakelijk het bestaan van een fout impliceert. Een afzonderlijke toetsing van het gedrag van de Staat aan de zorgvuldigheidsmaatstaf dringt zich verder op. ${ }^{265}$ Een vergissing van de wetgevende macht over de draagwijdte van een (open) grondwettelijke norm zoals het gelijkheidsbeginsel is derhalve niet noodzakelijk onzorgvuldig en brengt de aansprakelijkheid van de Staat niet ipso facto met zich mee, ${ }^{266}$ wat niet anders lijkt te zijn voor bestuurshandelingen ${ }^{267}$ dan voor wetgevende handelingen.

I29. Die rechtspraak is in verband te brengen met de rechtspraak van het Hof van Justitie en het erin gestelde vereiste van een voldoende gekwalificeerde schending. Wanneer een instelling van de Unie tot de betaling van een schadevergoeding wordt aangesproken, moet onder meer worden nagegaan of aan die instelling een voldoende gekwalificeerde schending van Unierecht is toe te rekenen. De loutere vaststelling van een onrechtmatigheid volstaat dus niet. Tot de feitelijke omstandigheden die in aanmerking kunnen worden genomen, behoren de 'ingewikkeldheid

265 Cass. Io september 20I0, AR F.o9.0042.N ('Het oordeel van het Grondwettelijk Hof, in het kader van een prejudiciële vraag, dat een wettelijke bepaling indruist tegen de artikelen io en II van de Grondwet heeft nog niet tot gevolg dat vaststaat dat de wetgever onrechtmatig heeft gehandeld in de zin van artikel ${ }_{3} 82$ van het Burgerlijk Wetboek. (...) De aansprakelijkheid van de wetgever vraagt een eigen beoordeling door de rechter aan wie gevraagd wordt de Staat te veroordelen op grond van een onrechtmatige daad.') Over beginselen van behoorlijke wetgeving, zie onder meer P. Popelier, 'Betere regelgeving: vijf uitdagingen voor juristen', RW 20II-I2, 28-35 (en vele van haar andere geschriften). Geen aansprakelijkheid in Rb. Leuven 26 januari 2007, TRV 20I3, I98, noot.

266 In de rechtsleer zijn uiteenlopende stemmen te horen. B. Dubuisson en S. Van Drooghenbroeck ('Responsabilité de l'Etat-législateur: la dernière pièce du puzzle?', JT 20II, p. 805, nr. I3) zien geen 'resultaatsverbintenis' in het gelijkheidsbeginsel en A. Wirtgen ('De overheidsaansprakelijkheid voor fouten van de wetgever: geen eenheid van ongrondwettigheid en fout', CDPK 20II, p. 297, nr. 6) uit minstens sterke twijfel over de vraag of het discriminatieverbod een welbepaald verbod zou inhouden, welke mening ook wordt gedeeld door H. Vandenberghe ('De beleidsmatige reactie op arresten van het Grondwettelijk Hof', CDPK 20Io, p. 374, nr. I2: 'Grondwetsbepalingen die duidelijk een verplichting aan de wetgever opleggen om niets te doen of op een welbepaalde wijze iets te doen zijn eerder zeldzaam'). T. Léonard (o.c., p. 960 e.v., nr. II e.v.) gaat duidelijk dezelfde richting uit. A. Alen ('De overheidsaansprakelijkheid voor fouten van de wetgever. Over de cassatiearresten van r juni 2006 en 28 september 2006', in W. Pintens, A. Alen, E. Dirix en P. Senaeve (eds.), Vigilantibus Ius Scriptum. Feestbundel voor Hugo Vandenberghe, Brugge, die Keure, 2007, I3) bepleit het vereiste van een gekwalificeerde fout in het kader van het wetgevend optreden, al is hij wel van oordeel dat zulks een ingreep van de wetgever vergt.

Daarentegen zien onder meer P. Popelier ('De zorgvuldige wetgever en de gekwalificeerde fout: een overvloedig respect voor de beleidsvrijheid van de wetgever' (noot onder Cass. Io september 20I0), RW 20I0-II, p. I727, nr. 4) en S. Guiliams ('Discriminatoir bevonden wetgeving houdt niet noodzakelijk een fout van de wetgever in', TFR 20II, (I97) nr. Io) in het discriminatieverbod een specifieke gedragsnorm. Zie ook T. Werquin, conclusie onder Cass. 2I december 2007, C.o6.0457.F (evenwel niet gevolgd door het Hof van Cassatie).

267 Zie met betrekking tot een bestuurshandeling: Rb. Brugge 30 april 20I2, onuitgeg., www. lokalebesturen.info/2012/05/de-schending-van-het.html. Zie ook het geval van de gesmokkelde vrachtwagen in Cass. 2I december 2007, AR C.06.0457.F, andersluidende conclusie T. Werquin (verwerpingsarrest - het kan de administratie douane en accijnzen niet worden verweten een wet toe te passen zolang het arrest van het Grondwettelijk Hof dat die wet ongrondwettig of nietig verklaart, niet is gepubliceerd). 
van de te regelen situaties en de moeilijkheden bij de toepassing of de uitlegging van de teksten' ${ }^{268}$ en de 'mate van duidelijkheid en nauwkeurigheid van de geschonden regel en de vraag of de rechtsdwaling opzettelijk of onverschoonbaar was'. ${ }^{269}$ In het geval Medici Grimm, waarin aansprakelijkheid werd afgewezen, wees het Hof erop dat er sprake was van een moeilijke rechtsvraag, waarvoor in de rechtspraak geen precedent bestond. ${ }^{270}$

Al geldt die vereiste van een voldoende gekwalificeerde schending niet als dusdanig wanneer de aansprakelijkheid van België voor een inbreuk op een Uniebepaling naar Belgisch recht wordt beoordeeld, ${ }^{271}$ het is wellicht toch niet uitgesloten dat de Belgische rechters bij de zorgvuldigheidsbeoordeling in het kader van artikelen $\mathrm{I}_{3} 82-\mathrm{I}_{3} 83 \mathrm{BW}$ met dezelfde beoordelingselementen rekening zouden kunnen houden in het kader van een geschil inzake de aansprakelijkheid van een lidstaat, ${ }^{272}$ althans wanneer is vastgesteld dat de geschonden rechtsregel geen welbepaald gebod of verbod met zich meebrengt.

\subsection{Beoordelingselementen}

I30. Na het overzicht van de verschillende situaties waarin de vergissing omtrent het bestaan of de draagwijdte van een toepasselijke rechtsregel een rol kan spelen, wordt hierna op de elementen ingegaan die in die beoordeling van de relevantie van de rechtsdwaling van belang blijken te zijn om inzicht te krijgen in de factoren die bepalen wie de last van de complexiteit van het rechtsgebeuren moet dragen.

\subsubsection{Nemo censetur ignorare legem}

I3I. Het adagium dat iedereen de wet hoort te kennen, is weliswaar geen rechtsregel (ook geen algemeen rechtsbeginsel), ${ }^{273}$ maar blijkt wel een beoordelingselement te

268 Gerecht 26 januari 2006, nr. T-364/03, Medici Grimm/Raad, ov. 8o.

269 Gerecht 26 januari 2006, nr. T-364/03, Medici Grimm/Raad, ov. 8I en 87.

270 Gerecht 26 januari 2006, nr. T-364/03, Medici Grimm/Raad, ov. 92.

27 I Zie Cass.I4 januari 2000, AR C.98.0477.F.

272 Zie HvJ 5 maart 1996, nr. C-46/93 en C-48/93, Brasserie du pêcheur en Factortame.

273 Cass. I4 januari 2013, AR C.I2.0059.N. Een ingeroepen schending van een rechtsspreuk die geen algemeen rechtsbeginsel is, kan op zich (dit is zonder schending van de wetsbepaling waarin ze desgevallend is vastgelegd) geen aanleiding geven tot cassatie (zie Cass. 25 februari I99I, AR 8885 inzake patere legem quam ipse fecisti; Cass. Io december 1993, AR C.93.0044.N inzake res perit debitori; Cass. 2 december 2002, AR C.98.0460.N inzake nemo auditur.)

Soms wordt het adagium wel als een algemeen rechtsbeginsel aangemerkt, zie bijv. Rb. Brugge I5 januari 2004, RW 2007-08, I255: 'Elk van de betrokken partijen draagt dus verantwoordelijkheid want er kan niet worden voorbijgegaan aan het algemeen rechtsbeginsel "nemo censetur ignorare legem" dat als zodanig tot ons positief recht behoort [...]. Hoewel dit beginsel niet inhoudt dat alle burgers alle wetten dienen te kennen, impliceert het wel degelijk dat de burger de wet dient te kennen die op hem van toepassing is in de omstandigheden waarin hij zich bevindt.' In andere uitspraken wordt het adagium dan radicaal afgewezen: Rb. Leuven 5 oktober 1994, RW I994-95, I06I, noot T. Hens: 'dat principe stamt uit zeer lang vervlogen tijden en actueel kent geen enkele Belg alle wetten'. 
zijn. Het is en blijft een beginsel, wat ook het Hof van Justitie en het Gerecht herhaaldelijk in de verf zetten. ${ }^{274}$

Het adagium komt in de rechtspraak ter sprake ten aanzien van wetgeving in de ruime zin van het woord. Zo verwees de Raad van State ernaar ten aanzien van gemeentelijke verordeningen:

'dat van hem die, zonder ingezetene van een gemeente te zijn, toch professionele of andere activiteiten op het grondgebied van die gemeente ontwikkelt, verwacht kan worden dat hij voldoende attent is om regelmatig kennis te nemen van de verordeningen die het gemeentebestuur uitvaardigt en die zijn activiteiten kunnen beïnvloeden; dat het wettelijk vermoeden van algemene bekendheid dat uit een regelmatige bekendmaking voortvloeit dan ook geldt ten aanzien van de belanghebbende niet-inwoners van de gemeente, zoals ter zake verzoekster er een is'. ${ }^{275}$

Het adagium geldt ook ten aanzien van de (gepubliceerde) rechtspraak vermits de wet pas doorheen de rechtspraak is te begrijpen, wat naar het adagium Nemo censetur ignorare jurisprudentiam verwijst. ${ }^{276}$

Het adagium doet dienst als een uitgangspunt om aan te geven dat het gebrek aan kennis van een rechtsregel of van de draagwijdte ervan niet tot gevolg kan hebben dat de rechtsregel niet toepasselijk zou zijn. ${ }^{277}$ Van dat uitgangspunt kan worden afgeweken als andere (hierna vermelde) beoordelingselementen zwaarder doorwegen. In die zin is het een vermoeden dat in uitzonderlijke omstandigheden ${ }^{278} \mathrm{kan}$ worden weerlegd, ook al wordt volgens sommigen te zelden een weerlegging aanvaard. ${ }^{279}$

274 HvJ 20 november 2008, Heuschen \& Schrouff, nr. C-38/07P, ov. 6I; HvJ 28 juni I990, Behn, nr. C-8o/89, ov. I3; HvJ I2 juli I989, Binder, nr. I6I/88, ov. I9; Gerecht I7 september 2003, Biegi Nahrungsmittel en Commonfood/Commissie, nr. T-309/or en nr. T-239/02, ov. 75; Gerecht 5 juni I996, Günzler/Commissie, nr. T-75/95, ov. 50 en 54.

275 RvS I6 februari I993, nrs. 4I.875 en 4I.986 (onontvankelijkheid van een beroep ratione temporis).

276 Zie S. De Somer en C. Fornoville, 'Rechtspraakpublicatie anno 20Ir: historische beschouwingen, hedendaagse bedenkingen en toekomstperspectieven', RW 20II-I2, 226.

277 In die zin bijvoorbeeld J. Dumortier, 'Wie wordt geacht de wet te kennen? Een voorstel voor een betere toegankelijkheid van de Belgische wetgeving', RW I992-93, 939.

278 Zeer uitzonderlijk is de beslissing tot strafrechtelijke vrijspraak van een jager die op zondag een inbreuk pleegde op een wet die de dag ervoor (zaterdag) in het Belgisch Staatsblad was gepubliceerd, met als expliciete motivering dat Nemo censetur ignorare legem 'op een menselijke aanvaardbare schaal' moet worden geïnterpreteerd (Corr. Turnhout II juni I990, Turnhouts Rechtsleven I990, I2I).

279 Zie in die zin B. Bouckaert, o.c., 66, voetnoot 446; J. Gielen, 'Beschouwingen bij enkele arresten van het Hof van Beroep te Antwerpen in verband met de rechtvaardigingsgronden in het sociaal strafrecht', RW I998-99, 836-845; E. Terryn, 'De informatieplicht van artikel 30 W.H.P.C. niet verzoenbaar met nemo censetur ignorare legem' (noot onder Brussel 3 mei 2002), DCCR 2003, 65. Vergelijk P. Dewael en V. Van Quickenborne, 'Overheid makkt werk van betere en beter toegankelijke wetgeving', De Juristenkrant 23 juni 2004, 4-5: 'Burgers en bedrijven moeten een zekere inspanning leveren om te weten welke regels zij dienen te respecteren. Deze inspanning moet echter wel binnen de grenzen van de redelijkheid blijven.' 


\subsubsection{De onwetendheid of goede trouw}

I32. Nemo censetur ignorare legem wordt niet geneutraliseerd door zich op onwetendheid of op goede trouw te beroepen. Aan het adagium komt daarom de betekenis toe dat niemand zich aan de toepassing van een rechtsregel kan onttrekken om de enkele reden dat hij of zij die regel niet kent. Dat goede trouw niet volstaat, wordt in rechtspraak en rechtsleer herhaaldelijk bevestigd. ${ }^{280}$

Goede trouw is daarentegen wel een noodzakelijke voorwaarde om een rechtsdwaling met succes in te roepen ${ }^{28 \mathrm{r}}$ zoals onder meer wordt bevestigd door de rechtspraak omtrent de bescherming van het rechtmatig vertrouwen van de burger in zijn verhouding met de overheid.

\subsubsection{De aard van de rechtsregel}

I33. Volgens een aantal auteurs, actief in de $19^{\mathrm{e}}$ eeuw, kan een rechtsdwaling ten aanzien van een bepaalde categorie van rechtsregels nooit als excuus worden ingeroepen. Een vergissing kwam volgens hen niet in aanmerking ten aanzien van rechtsregels van openbare orde. Die opvatting werd het duidelijkst door Laurent verwoord:

'Les lois, par leur essence, obligent tous les citoyens, il n'y aurait pas de société possible si les lois n'avaient pas une force obligatoire indépendante de l'ignorance, du caprice ou du mauvais vouloir de ceux qu'elles obligent. Cela implique que notre présomption est fondée sur un intérêt social. Mais si la loi est une loi d'intérêt privé, s'il s'agit de rapports entre particuliers, on ne peut plus dire qu'ils sont censés connaître la loi, et que l'ignorance du droit ne les excuse point. ${ }^{282}$

Ook De Page was die opvatting genegen vermits hij geen rekening wilde houden met een vergissing omtrent het recht in de hypothese dat 'l'erreur de droit étant admise, on aboutirait à la violation d'une loi d'ordre public'. ${ }^{283}$

280 Cass. 2I september I994, AR P.94.0659.F (misdrijf); RvS I3 december 20I0, nr. 209. 686 ('sa bonne foi ne constitue pas un moyen de droit'); Gent I3 december 2000, AR 294/99; Corr. Brugge 8 november I984, RW I985-86, I229, noot P. Arnou; Corr. Antwerpen 4 november I987, RW I99I-92, 962, noot; P. Van Den Bon, noot onder Antwerpen 9 oktober 1997, Soc. Kron. I998, I47 ('Onwetendheid kan echter niet volstaan als vrijbrief'). Zie onder meer C.-E. Clesse, 'Les causes de justification en droit pénal social', Orientations, mei 2007, 5; B. De Smet, o.c., I29I; J. Gielen, 'Beschouwingen bij enkele arresten van het Hof van Beroep te Antwerpen in verband met de rechtvaardigingsgronden in het sociaal strafrecht', RW I998-99, 840, met verdere verwijzingen.

28I Luik 7 januari 2009, zoals door B. Jadot samengevat in Amén. 2009, 2I6; Rb. Namen, zoals samengevat door P. Bouillard in Amén. 1994, I52. Zie bijv. N.A. De Vos, 'Het vertrouwensbeginsel in rechtsvergelijkend perspectief met inbegrip van het Europese vertrouwensbeginsel', CDPK 20I2, p. 543, nr. I9.

282 Zie F. Laurent, Principes de droit civil, Bruylant, I, nr. 24; zie ook C. De Koninck, Latijnse rechtsspreuken, Gent, Mys \& Breesh, I997, III; H. De Page, Traité élèmentaire de droit civil belge, I, I962, Brussel, Bruylant, nr. 42. Zie ook F. Laurent, o.c., II, nr. 504: 'Nous avons dit ailleurs que cet adage traditionnel n'est applicable que quand la loi impose une obligation à l'exécution de laquelle la société est intéressée. Elle ne reçoit pas d'application dans les relations d'intérêt privé.'

283 H. De Page, Traité élémentaire de droit civil belge, I, I962, Brussel, Bruylant, nr. 42. 
Van die opvatting lijken er geen (minstens geen uitdrukkelijke) sporen meer in het huidige recht aan te treffen. In de rechtspraak wordt geen onderscheid gemaakt naargelang een rechtsregel al dan niet van openbare orde is. In zijn preadvies van circa 20 jaren geleden beweerde Bouckaert dan ook dat dit onderscheid niet tot het positieve recht zou behoren. ${ }^{284}$

Integendeel, in het strafrecht, materie bij uitstek van openbare orde, zijn van het adagium meer toepassingen in de (gepubliceerde) rechtspraak dan in de civielrechtelijke sfeer aan te treffen. ${ }^{285}$ Wel verklaart het openbareordekarakter van het mededingingsrecht en van de staatssteunregels waarom voor de rechtsdwaling volgens de rechtspraak van het Hof van Justitie slechts zeer uitzonderlijk plaats wordt ingeruimd. ${ }^{286}$ Hetzelfde kan worden gezegd van de rechtspraak van het Hof van Cassatie met betrekking tot het beginsel van de bescherming van het rechtmatig vertrouwen in fiscale en socialezekerheidszaken. ${ }^{287}$ Die rechtstakken behoren immers tot de fundamentele economische grondslagen waarop de organisatie van de samenleving rust, zodat een onrechtmatigheid op dat vlak niet zomaar door een vergissing kan worden vergoelijkt.

Het openbareordekarakter van een rechtsregel blijkt aldus geen absolute hinderpaal om een vergissing als excuus voor een inbreuk op dergelijke regel aan te voeren, maar het verklaart wel de terughoudendheid waarmee een vergissing met betrekking tot een rechtsregel van openbare orde wordt aangenomen.

Zulks is in verband te brengen met het individueel en het collectief belang, alsook met het belang van de bescherming van de burger tegen willekeur van de overheid, zoals tot uitdrukking komt in de fundamentele beginselen van (welbegrepen) legaliteit, rechtszekerheid en bescherming van het rechtmatig vertrouwen. Alleen blijft de vraag wanneer het ene beginsel voor het andere moet wijken. Auteurs die het vertrouwensbeginsel bestudeerden, lijken voor het individueel belang van de burger meer ruimte te willen laten dan momenteel uit de huidige rechtspraak volgt: 'Naargelang de concrete belangenafweging zal het belang van de betrokkene bij honorering van het vertrouwen doorwegen, dan wel het algemene belang of derde-belangen. ${ }^{288}$ Popelier, samen met andere auteurs, ${ }^{289}$ is kritisch met betrekking tot het cassatiearrest van I5 februari 2013 in fiscale zaken (zie paragraaf I23), omdat het 'suggereert dat een voorzichtige burger aan het bestuur uitdrukkelijk zekerheid had kunnen vragen over de correcte kwalificatie'. ${ }^{200}$ Als dat de suggestie van dat

284 B. Bouckaert, o.c., p. I37I, nr. II e.v.; B. De Smet, o.c., I295.

285 Zie boven, nrs. I2I.

286 Zie boven, nrs. I24.

287 Zie boven, nrs. I23.

288 N.A. De Vos, 'Het vertrouwensbeginsel in rechtsvergelijkend perspectief met inbegrip van het Europese vertrouwensbeginsel', CDPK 2012, p. 538, nr. 6 (ook p. 544, nr. 23 en p. 546-547, nr. 28).

289 V. Dauginet en B. Ameye, o.c., 3-38, die pleiten voor een bredere toepassing van het vertrouwensen rechtszekerheidsbeginsel in overeenstemming met de rechtspraak van het Hof van Justitie en het EHRM.

290 In die zin het kritische artikel van P. Popelier, 'Het vertrouwensbeginsel versus het legaliteitsbeginsel: het kalf is verdronken, maar wanneer dempt men de put?' (noot onder Cass.I5 februari 2013), AFT 2013, 50-55. 
cassatiearrest is, legt dit toch een betere balans tussen het individueel en het collectief belang dan Popelier beweert.

\subsubsection{De duidelijkheid van een norm}

134. Van een rechtsregel mag worden verwacht dat hij duidelijk is. Dit is de opvatting van vooraanstaande auteurs ${ }^{291}$ en komt tevens tot uiting in de rechtspraak van de hoogst geplaatste Hoven. De duidelijkheidseis is een onderdeel zowel van het rechtszekerheidsbeginsel als van het legaliteitsbeginsel in de brede zin van het woord.

Vermits een rechtsregel steeds interpretatie behoeft, zou hij, in theorie, altijd onduidelijk kunnen worden genoemd. De beslissing dat een regel duidelijk is, steunt immers op een daaraan voorafgaande interpretatie. Toch wordt in de rechtspraak herhaaldelijk aangenomen dat een regel duidelijk is om een dwaling omtrent het bestaan of de draagwijdte ervan als excuus te verwerpen. ${ }^{292}$

Hoe onduidelijker de rechtsregel wordt geacht, hoe groter de kans is dat het uitgangspunt van Nemo censetur ignorare legem onderuit wordt gehaald. Een onduidelijke rechtsregel is evenwel niet te vereenzelvigen met een complexe rechtsregel. Een rechtsregel kan wat denk- en opzoekingswerk vergen om die te begrijpen, maar eens opgezocht en uitgedacht (door de rechtzoekende of de beroepsbeoefenaar aan wie informatie of advies wordt gevraagd), kan een complexe norm niettemin voldoende duidelijk zijn om het gedrag daarop te richten. De complexiteit van een rechtsregel volstaat dus niet om te ontkomen aan de rechtsgevolgen van een inbreuk op die regel. ${ }^{293}$ Omtrent een complexe rechtsregel kan men zich immers (laten) informeren en/of adviseren. ${ }^{294}$

Dat een norm niet door duidelijkheid uitblinkt, betekent dus niet dat er plaats is voor dwaling of vergissing als excuus. ${ }^{295}$ Wanneer een rechtsregel evenwel complex of aleatoir wordt genoemd omdat de erin gebruikte begrippen voor uiteenlopende interpretaties vatbaar zijn, zelfs rekening houdend met de doelstellingen van de wetgever, en in de rechtspraak en rechtsleer op tegenstrijdige wijzen worden ingevuld,

29I Zie onder meer S.J. Shapiro, Legality, Cambridge, Harvard University Press, 20II, 393.

292 Zie HvJ 26 april I988, nr. 316/86, Krücken, ov. 24; HvJ I april ı993, nr. C-33/9I, Lageder e.a., ov. 35; HvJ I6 maart 2006, nr. C-94/05, Emsland-Stärke, ov. 31: het vertrouwensbeginsel kan niet tegen een duidelijke kartelrechtelijke bepaling worden ingeroepen. Zie verder in het strafrecht Antwerpen 28 november 200I, T. Milieurecht 2003, 519 (meststoffendecreet); Arbrb. I2 september I995, Soc. Kron. 1996, 245, noot (tekst duidelijk; andersluidende interpretaties geen onoverkomelijke rechtsdwaling van een werkgever in het kader van een burgerlijke vordering wegens misdrijf). In het administratief recht, zie RvS I3 december 2010, nr. 209.686 (dwaling ingeroepen om te ontkomen aan de onontvankelijkheid van een verzoek bij de Raad van State).

293 Zie met betrekking tot milieuwetgeving M. Faure, 'De onoverkomelijke rechtsdwaling in milieustrafzaken', RW I99I-92, p. 942, nr. II; F. Van Volsem, 'De onoverwinnelijke rechtsdwaling en de noodtoestand in het bijzonder met betrekking tot milieumisdrijven', TMR 20I2, p. 9, nr. 36. Met betrekking tot sociaal recht: Arbrb. Bergen I4 mei 20Io, JTT 20I0, 349 ('la complexité du droit social ne peut à elle seule être invoquée au titre de cause de justification') en Arbh. Luik I4 oktober 2005, JTT 2006, 447 (inzake bij te houden lijsten van aanwezige werknemers op een bouwwerf).

294 M. Faure, o.c., p. 942, nr. II.

295 Zie het quad-geval in Rb. Brugge I5 januari 2004, RW 2007-08,I255. 
zonder dat daaraan door een hooggeplaatst rechtscollege een eind is gesteld, dan ligt het meer voor de hand om rechtsdwaling als excuus in te roepen, althans voor een leek. ${ }^{296}$

\subsubsection{De kennis, de ervaring en de maatschappelijke positie van de rechtsonderhorige}

I35. De zwakke maatschappelijke positie van een rechtsonderhorige is op zichzelf onvoldoende om een rechtsinbreuk goed te praten, ${ }^{297}$ maar kan niettemin een beoordelingselement zijn.

De beperkte ervaring van een marktdeelnemer is een factor waarmee volgens de rechtspraak van het Hof van Justitie, in het kader van navordering van douanerechten, rekening is te houden. Herhaaldelijk is benadrukt dat het, bij de beoordeling van de vraag of het vertrouwen van een marktdeelnemer inzake een bepaalde lezing van een rechtsregel al dan niet rechtmatig is, relevant is te weten of deze 'zich hoofdzakelijk bezighoudt met de in- en uitvoer van goederen en die op dit gebied reeds zekere ervaring heeft opgedaan'. ${ }^{298}$ Meer nog, in het kader van de staatssteunregels is de enkele hoedanigheid van marktdeelnemer voldoende om rechtsdwaling uit te sluiten, wanneer de staatsteun niet voorafgaand bij de Commissie werd gemeld.

Hierboven is, in de context van een onverschoonbare dwaling, reeds op het belang van de professionele hoedanigheid van de dwalende partij (alsook het gebrek aan die hoedanigheid van de medecontractant) gewezen (zie het voorbeeld van de tandarts en de vastgoedontwikkelaar in paragraaf I20). $_{2}$

\subsubsection{De informatie-, onderzoeks- en adviesplicht van de rechtsonderhorige}

136. Indien een rechtsonderhorige wordt geconfronteerd met een situatie waarin hij/zij niet weet hoe ze juridisch is geregeld, dan wordt op de maatschappelijke plicht gewezen om zich nader te informeren, zodat hij/zij zijn/haar gedrag daarop kan afstemmen. ${ }^{299}$ Tegenover de vrijheid van elkeen staat ook een maatschappelijke verantwoordelijkheid. Dit is niet minder maar precies meer het geval met betrekking tot een complex geregelde materie. ${ }^{300}$ Het Grondwettelijk Hof heeft bevestigd dat adviesinwinning, onder omstandigheden, mag worden verwacht: 'dat de voorzienbaarheid van de wet zich er niet tegen verzet dat de betrokkenen ertoe worden aangezet een beroep te doen op bekwame raadslieden om de gevolgen die uit

296 Zie Arbh. Antwerpen I3 februari 2007, Soc. Kron. 2007, 304 (misdrijf onoverkomelijke dwaling). Zie ook Arbrb. Bergen I4 mei 20I0, JTT 20I0, 349 (oplijsting van onzekerheden met betrekking tot de vraag of bij de bepaling van het nettomaandinkomen, berekeningsbasis voor een burgpensioenvergoeding, rekening is te houden met een tewerkstellingsbonus, met als gevolg dat niet de verjaringsregels van artikel 26 V.T.Sv., maar van artikel I5 WAO worden toegepast), te vergelijken met Cass. 28 maart 20I2, P.II.2083.F (vernietigingsarrest omdat ten onrechte onoverkomelijke dwaling uit feitelijke vaststellingen was afgeleid, waardoor artikel 26 V.T.Sv. niet werd toegepast). Zie ook F. Van Volsem, o.c., p. 9, nr. 36.

297 Zie onder meer P. Van den Bon, noot onder Antwerpen 9 oktober 1997, Soc. Kron I998, I45.

298 Gerecht I7 september 2003, nr. T 309/0I en T 239/02, Biegi en Commonfood, ov. 75 .

299 Bijvoorbeeld Arbh. Luik I4 oktober 2005, JTT 2006, 447.

300 Zie bijvoorbeeld B. De Smet, o.c., I29I. Zie ook M. Faure, o.c., p. 949, nr. 22. 
een bepaalde handeling kunnen voortvloeien tot op een bepaald niveau, dat binnen de omstandigheden van de zaak redelijk is, te beoordelen' ${ }^{301}$

De bronnen van informatie zijn breed en uiteenlopend van aard. Een rechtsonderhorige zal vandaag de dag doorgaans beginnen met een (min of meer betrouwbare) zoekopdracht op het internet. Hij/zij kan ook een belangenorganisatie raadplegen (zoals een vakbond, een werkgeversorganisatie, een consumentenorganisatie, enz.), een vroegere leraar of professor bevragen of een professioneel opbellen om een kort dan wel omstandig (schriftelijk) advies te vragen. Die beroepsbeoefenaar kan een juridische opleiding hebben gehad of kan de juridische kant van een technische, economische, fiscale of boekhoudkundige activiteit kennen (zoals een aannemer of architect, een bedrijfsrevisor, een accountant of een boekhouder). De informatie kan ook (mondeling of schriftelijk) bij de overheid worden ingewonnen.

Ook wanneer de rechtsonderhorige inspanningen heeft geleverd om de toepasselijke rechtsregel te kennen, wordt een rechtsdwaling niet snel aanvaard, zoals uit de rechtspraak zowel van het Hof van Cassatie als van het Hof van Justitie blijkt.

Het Hof van Cassatie stelt strenge eisen, zoals uit de Freddy-zaak blijkt. Een oudere dame had het beschikbare gedeelte van haar nalatenschap bij testament aan haar twee kleinzonen ten nadele van haar zoon toebedeeld. Een belangrijk, vaak onvermeld gelaten, feit is daarbij dat in dat testament was bepaald ${ }^{302}$ dat wanneer een kleinzoon aan het legaat zou verzaken, dat deel van de nalatenschap aan de andere (niet verzakende) kleinzoon zou toekomen. Een van de kleinzonen, Freddy, verzaakte aan zijn legaat, in de overtuiging verkerend dat zijn deel aan zijn vader zou toekomen. Hij was tot die overtuiging gekomen op grond van het advies van een advocaat ingeschakeld door zijn vader, en van een notaris. Aan Freddy kon niet worden verweten dat hij geen professioneel advies heeft ingewonnen, zodat er felle kritiek kwam ${ }^{303}$ op de beslissing van de feitenrechter die de dwaling, ondanks de juridische adviezen, niet verschoonbaar achtte en de vordering tot vernietiging van de verzaking door Freddy afwees, alsook op het latere verwerpingsarrest van het Hof van Cassatie.

Die beslissingen zijn evenwel begrijpelijk in het licht van de tekst zelf van het testament, aangevend dat bij verzaking van één kleinzoon het desbetreffende aandeel aan de andere kleinzoon toekomt. Die bepaling verklaart waarom het Hof van Cassatie de voorziening heeft verworpen tegen de beslissing dat 'een onverschoonbare en op zichzelf niet onoverkomelijke dwaling niet verschoonbaar en onoverkomelijk wordt omdat zij [...] eveneens begaan werd door de juridische raadslieden' omdat aldus geen grotere zorgvuldigheid wordt geëist dan die uitgaande van een redelijk mens. ${ }^{304}$ Dit arrest wordt door de feitenrechters zo gelezen dat die regel alleen geldt wanneer de dwaling door een jurist werd gedeeld met de contractpartij, maar niet

301 GWH I3 juli 2005, nr. I25/2005, ov. B.6.2.

302 Aldus R. Kruithof, o.c., TPR I983, 552, nr. 47.

303 Zie B. Bouckaert, o.c., p. I383-I384; J. Stevens, 'Hoe gemeen is het gemene recht', RW I979-I980, kol. I6I5-I6I6; M. Coipel, o.c., 2I7-2I9; F. Glansdorff, o.c., p. 735-737, nrs. I4-I6.

304 Cass. Io april I975, Arr. Cass. I975, 87I. 
wanneer ze door de jurist werd veroorzaakt. ${ }^{305}$ De grens tussen beide situaties lijkt niet haarfijn af te lijnen.

Het Hof van Cassatie is even streng omtrent de vraag wanneer een advies een rechtsdwaling onoverkomelijk maakt en aldus de buitencontractuele fout of het misdrijf uitsluit. De kernoverweging van het Hof is dat 'de loutere vaststelling dat het slachtoffer van de dwaling, slecht werd geadviseerd, zelfs door een deskundige, niet voldoende is' ${ }^{306}$ Uit diezelfde rechtspraak blijkt dat moet worden nagegaan of de beklaagde of het slachtoffer van de dwaling, in de concrete omstandigheden, 'gehandeld heeft zoals ieder redelijke en voorzichtige persoon zou hebben gehandeld'. Volgens De Smet betekent dit dat 'een normaal zorgvuldig persoon redelijkerwijs mag veronderstellen dat zijn advocaat het recht kent wanneer bij hem informatie wordt ingewonnen over een complexe aangelegenheid', met dien verstande dat het advies (I) voorafgaand aan het misdrijf wordt ingewonnen, (2) de inbreuk onoverkomelijk is, (3) het advies volledig is, (4) de betrokkene zich niet blind staart op het advies en (5) het advies persoonlijk gericht is tot degene die er zich op beroept. ${ }^{307}$ Of een rechtsdwaling ook volgens de rechtspraak onoverkomelijk wordt zodra aan die criteria is voldaan, is nog maar de vraag.

Drie arresten zijn illustratief voor de terughoudendheid van de rechtspraak van het Hof van Cassatie, ook al is voorzichtigheid bij de interpretatie ervan geboden..$^{308}$

305 Zie Rb. Hasselt 2 april 200I, RW 2004-05, (75I) 755: 'Aangenomen dat een op zichzelf onverschoonbare dwaling niet verschoonbaar wordt, indien de dwalende werd bijgestaan door een deskundige, die dezelfde dwaling deelt, moet in casu evenwel worden opgemerkt dat de dwaling van de verkopers niet alleen werd gedeeld door [de notaris], maar ook door hem werd veroorzaakt, ook al werd hij op zijn beurt misleid door de brief van het gemeentebestuur.'

Nog andere lagere rechtspraak neemt wel eens een extern advies aan om een strafrechtelijke vrijspraak uit af te leiden, zie Corr. Turnhout 28 mei I990, Turnhouts Rechtsleven I990, I22.

306 Cass. 3i oktober I994, RW I994-95, II22, Arr. Cass. I994, I, 898, noot J.F.L. Zie ook Cass. 29 november I970, Arr. Cass. I977, 360; Cass. 20 april I982, RW I983-84, kol. 2919 (advies aannemer aan bouwheer); Cass. 29 april 1998, Arr. Cass. 1998, p. 480, nr. 219; Cass. I8 januari 1999, RCJB 2000, 725, noot F. Glansdorff; Cass. I oktober 2002, RABG 2003, 798, noot L. Delbrouck.

307 Zie B. De Smet, o.c., I293-I294.

308 Voor andere arresten: Cass. I9 juni I980, Arr. Cass. I979-80, I309 (verwerpingsarrest - abortus); Cass. 29 mei 2002, Arr. Cass. 2002, 1375 (vernietigingsarrest - volgens de feitenrechter had de betrokken werkgever vertrouwen gesteld 'in de instructies die hem [door een vennootschap, die belast was met het beheer van de fiscale en sociale verplichtingen van de naamloze vennootschap Jocari] in een bijzonder ingewikkelde materie zijn gegeven door iemand die geacht wordt die materie beter dan wie ook te kennen' - het Hof van Cassatie vernietigde het arrest omdat 'niet blijkt dat verweerder, tijdens het in aanmerking genomen tijdvak van de misdrijven, aanwijzingen van dat kantoor heeft verkregen over de niet-betaling van de eindejaarspremies'. Cass. I5 november I988, Pas. I989, I, 276 (videocassettegeval - vernietigingsarrest - 'que, toutefois, la constatation du fait que certains membres non précisés du ministère public n'exercent pas de poursuites pénales n'implique pas que telle soit l'attitude du ministère public en général, de sorte qu'une erreur invincible ne peut s'en déduire; que, pour le surplus, l'avis adressé à certains commerçants par des services de police au moyen d'un document mentionné par l'arrêt ne permet pas non plus de conclure à l'erreur invincible, l'arrêt ne constatant ni que l'ensemble ou la majorité des services de police ont adressé pareil avis à tous les collègues du défendeur ou à un grand nombre de ceux-ci ni que celui-ci s'est fait renseigner par des personnes compétentes en ce qui concerne la conformité de ces avis aux dispositions légales et en ce qui concerne la politique suivie par le ministère public de son arrondissement'). 
In het cabaretière-arrest van 29 november $1976^{3^{\circ 0}}$ had een advocaat zijn cliënte, die wegens het aanzetten tot ontucht was veroordeeld, geadviseerd haar handelsactiviteit als herbergierster voort te zetten, wat juridisch onjuist was. De feitenrechter kon, volgens het Hof van Cassatie, geen onoverkomelijke rechtsdwaling van de cliënte uit het advies van de advocaat afleiden, omdat niet ieder redelijk en voorzichtig persoon ervan zou zijn uitgegaan dat het advies de toepasselijke wetgeving correct weergaf. Volgens Verhaert en Waeterinckx brengt dit arrest met zich mee dat de kans dat een rechter rechtsdwaling aanvaardt, 'eerder gering' is..$^{310}$

In het beroepsgeheimarrest van I oktober $2002^{3 \mathrm{II}}$ waren ouders van een kindje dat bij een medische behandeling in een ziekenhuis overleed, gekrenkt door een persbericht dat het beroepsgeheim van de aangesproken geneesheren schond. De verweerders beriepen zich op het juridisch advies dat ze hadden ingewonnen bij 'drie advocaten met een onbetwistbaar gezag en met een jarenlange ervaring als advocaat', wat door de feitenrechter als onoverkomelijke dwaling werd gekwalificeerd, tezamen met de vaststelling dat het persbericht pas werd verspreid nadat het juridisch onderzocht was en aangepast was. Het Hof van Cassatie vernietigde die beslissing bij gebreke aan voldoende vaststellingen om tot een onoverkomelijke dwaling te kunnen besluiten. Volgens de annotatie vernietigde het Hof omdat 'steeds een in concreto beoordeling dient te gebeuren en het onvoldoende is om - algemeen het loutere feit van een slecht geadviseerd zijn te vermelden'. Wellicht is het cassatiearrest te verklaren door het feit (zulks blijkt uit het cassatiemiddel) dat geen advies blijkt te zijn gevraagd over de vraag of het persbericht al dan niet met een schending van het beroepsgeheim gepaard ging, al is dat door het Hof van Cassatie niet met zoveel woorden gezegd.

Het kasbonarrest van i9 mei $1987^{312}$ is gunstiger voor de rechtsonderhorige die zich omtrent het recht heeft vergist voortgaand op een advies van een professioneel. Een persoon, vervolgd wegens diverse beweerde valsheden inzake kasbons, werd vrijgesproken op grond van zijn bewering dat de "notaris zou hebben gezegd dat zij de effectenoverdracht niet moest aangeven omdat de effecten niet tot de nalatenschap behoorden' en dat de notaris zich dit niet meer herinnerde, maar die mogelijkheid niet uitsloot. De cassatievoorziening werd verworpen omdat het een onaantastbare feitelijke beoordeling betrof, niet zonder vooraf te hebben herhaald dat een onjuist advies op zichzelf niet volstaat om een strafrechter toe te laten een onoverkomelijke dwaling te besluiten. ${ }^{313}$

Uit die illustraties volgt dat de cassatierechtspraak niet zomaar genoegen neemt met een advies van één of zelfs meerdere advocaten, wat de kritiek heeft uitgelokt dat het Hof te streng is en zelfs zo streng dat het nogal licht de feitelijke toer opgaat

309 Cass. 29 november 1976, Arr. Cass. 1977, 359, Pas. I977, I, 355 (vernietigingsarrest).

3I0 I. Verhaert en P. Waeterinckx, o.c., Ioog.

3II Cass. I oktober 2002, RABG 2003, 798, noot L. Delbrouck, 'Ook een advocaat kan zich vergissen'.

3I2 Cass. I9 mei I987, RW I987-88, 675, noot R. Verstraeten, die schrijft dat het Hof 'duidelijk soepeler' is dan in bijvoorbeeld het arrest van 29 (niet 30) november 1976.

3 I3 R. Verstraeten (o.c., 676) en F. Van Volsem (o.c., p. II, nr. 45) lezen hierin dat niet uitdrukkelijk moet worden vermeld dat elke normaal zorgvuldige zoals de beklaagde zou hebben gehandeld, maar de vaststelling volstaat dat het advies 'in concreto aanleiding heeft gegeven' tot de onoverkomelijke dwaling. 
daar waar de onoverkomelijke rechtsdwaling in een concreet geval door de feitenrechter is aanvaard. ${ }^{314}$

Ook het Hof van Justitie stelt zich streng op. Dit is bijvoorbeeld het geval wanneer de rechtsonderhorige alleen maar een leidraad van een nationale lidstaat omtrent de tariefindeling in de douanewetgeving heeft geconsulteerd. Herhaaldelijk benadrukte het Hof van Justitie dat de justitiabele zich door lezing van het officiële publicatieblad moet informeren. ${ }^{315}$

Recent is de vraag naar de impact van een positief advies van een advocaat (of een besluit van een nationale mededingingsautoriteit) in het geval van Europese mededingingsinbreuken aan bod gekomen. Het uitgangspunt is dat een onderneming niet aan een geldboete wegens een mededingingsinbreuk kan ontsnappen doordat zij zich als gevolg van het advies van een advocaat (of een besluit van een nationale mededingingsautoriteit) over de rechtmatigheid van haar gedrag heeft vergist.

Het Hof overweegt dat een onjuiste juridische kwalificatie van gedrag geen excuus is 'wanneer [de onderneming] niet onkundig kon zijn van het mededingingsverstorende karakter van dat gedrag', zoals in het geval van rechtstreekse afspraken over verkoopprijzen. ${ }^{316}$ In een dergelijke situatie kon een (verkeerd) advies van een advocaat niet baten (evenmin als een (verkeerd) besluit van een nationale mededingingsrecht). Die zienswijze blijkt een algemene draagwijdte te hebben. Het Hof lijkt immers aan de gebeurlijke impact van een advies van de advocaat de doodsteek te geven door de overweging dat uitzonderlijk kan worden beslist om geen geldboete op te leggen, wat 'met name het geval [kan] zijn wanneer een algemeen beginsel van Unierecht, zoals het beginsel van het gewettigd vertrouwen, zich verzet tegen de oplegging van een geldboete', wat alleen het geval kan zijn indien er sprake is van concrete toezeggingen van de bevoegde overheidsinstantie, maar niet het geval is bij een advies, verstrekt door een advocaat. ${ }^{\text {17 }}$ Of dit arrest voor dwaling ruimte laat buiten de bescherming van het gewettigd vertrouwen, is niet volledig uit te sluiten, maar lijkt toch eerder onwaarschijnlijk te noemen.

Het Hof is aldus klaarblijkelijk niet zo ver gegaan als Advocaat-Generaal Kokott in haar conclusie voorafgaand aan het Schenker-arrest heeft willen gaan. Uit die conclusie blijkt hoe Kokott worstelde met het spanningsveld tussen enerzijds het feit dat de deur niet kan worden opengezet voor 'puur welgevallige adviezen' en anderzijds het feit dat ondernemingen sinds I mei 2004 geen vaststelling meer kunnen bekomen dat hun voorgenomen gedrag niet met het Europese mededingingsrecht strijdt:

'Het is onaanvaardbaar om enerzijds ondernemingen aan te moedigen juridisch advies in te winnen, en anderzijds aan dergelijk advies geen enkele betekenis toe te kennen bij de beoordeling of

3I4 Zie bijv. T. Balthazar, 'Het gedeeld beroepsgeheim is geen uitgesmeerd beroepsgeheim', T.Gez. 2004-05, I4I, met verdere verwijzingen.

3 I5 Bijvoorbeeld in HvJ 20 november 2008, nr. C-38/07, Heuschen \& Schrouff, ov. 6I e.v.; Gerecht 30 november 2006, nr. T-382/04, Heuschen \& Schrouff, ov. 68-69.

3 I6 HvJ I8 juni 20I3, nr. C-68I/II, Schenker, ov. 38-39.

317 HvJ I8 juni 20I3, nr. C-68I/II, Schenker, ov. 40-43. 
ondernemingen die het mededingingsrecht hebben geschonden, culpoos hebben gehandeld. Als een onderneming te goeder trouw heeft vertrouwd op het - uiteindelijk onjuiste - advies van haar juridisch adviseur, kan dit in kartelrechtelijke boeteprocedures niet zonder gevolgen blijven. ${ }^{3} 18$

Zij overweegt daarbij uitdrukkelijk dat een geschil in aansprakelijkheid tegen de advocaat 'op zichzelf onvoldoende soelaas' biedt en evenmin het stigma gekoppeld aan een mededingingsinbreuk wegpoetst..$^{\text {19 }}$

In het door haar geschetste spanningsveld ziet Advocaat-Generaal Kokott de mogelijkheid dat rechtsdwaling als excuus kan gelden op voorwaarde dat het advies aan de volgende minimumeisen voldoet en de onderneming te goeder trouw handelt: (I) het advies gaat uit van een onafhankelijke, externe advocaat, niet van een bedrijfsjurist; (2) het gaat uit van een deskundige advocaat, 'wat betekent dat de advocaat gespecialiseerd moet zijn in het mededingingsrecht, dat van de Unie daaronder begrepen, en bovendien de nodige ervaring op dit rechtsgebied moet hebben opgedaan'; (3) het advies is gebaseerd op een 'volledige en correcte uiteenzetting van de feiten door de betrokken onderneming'; (4) het advies moet 'een grondige uiteenzetting bevatten van zowel de beslissings- en administratieve praktijk van de Commissie als de rechtspraak van de Unierechter, en daarbij uitvoerig ingaan op alle juridisch relevante aspecten van het betrokken geval. Wat niet expliciet in het advies aan de orde komt, maar hoogstens impliciet daaruit valt af te leiden, kan geen reden zijn om disculperende rechtsdwaling aan te nemen'; (5) het advies mag niet kennelijk onjuist zijn. De omvang en de ervaring van de onderneming met mededingingsrechtelijke aangelegenheden vindt Kokott bepalend om de zorgvuldigheidsgraad in te vullen: 'Hoe groter een onderneming is en hoe meer ervaring zij met het mededingingsrecht heeft, hoe intensiever zij het door haar ingewonnen juridisch advies op zijn inhoud moet toetsen, vooral wanneer zij over een eigen juridische afdeling met vergelijkbare experten beschikt', met dien verstande dat niemand mag deelnemen aan hardcore-restricties zoals prijsafspraken. 'Van grote en ervaren ondernemingen kan bovendien worden verlangd dat zij kennis hebben genomen van de relevante mededelingen die de Europese Commissie in haar bekendmakingen en richtsnoeren op het gebied van het mededingingsrecht heeft gedaan'; (6) de onderneming handelt ten slotte op eigen risico als er twijfel blijkt uit het juridisch advies: zij 'neemt dan namelijk op zijn minst uit onachtzaamheid op de koop toe dat zij met haar marktgedrag de regels van het Europese mededingingsrecht schendt', met een waarschuwende vinger naar de 'advocaat die zich door het opstellen van welgevallige adviezen medeplichtig aan concurrentiebeperkende praktijken van ondernemingen makkt, niet alleen civielrechtelijke en tuchtrechtelijke consequenties heeft te vrezen, maar bovendien wellicht ook zelf kartelrechtelijke sancties opgelegd kan krijgen'. ${ }^{20}$

3 I8 J. Kokott, conclusie van 28 februari 2013 in de zaak C-68I/II, Schenker, nr. 58.

3 I9 J. Kokott, conclusie van 28 februari 2013 in de zaak C-68I/II, Schenker, nr. 59.

320 Voor de diverse citaten, J. Kokott, conclusie van 28 februari 2013 in de zaak C-68I/II, Schenker, nr. $65-73$. 
Het Hof van Justitie gaat niet zo ver mee in de denkoefening als Advocaat-Generaal Kokott, ${ }^{321}$ wat mogelijk te maken heeft met het feit dat de mededingingsinbreuk in Schenker op een hardcore-restrictie betrekking had, waarvoor noch AdvocaatGeneraal Kokott, noch het Hof van Justitie de ogen wil sluiten. In dergelijke situaties kan er geen sprake zijn van de aanname van een disculperende dwaling.

Bij nader toezien is Advocaat-Generaal Kokott niet zo goedschiks met advocatenadviezen als op het eerste gezicht kan worden gedacht. Vooral haar laatste minimumeis, dat twijfel voor rekening van de betrokken onderneming blijft, geeft de doodsteek aan de dwaling als excuus. ${ }^{322}$ Inderdaad, regelmatig (bijvoorbeeld in het kader van het wilsgebrek dwaling) wordt beklemtoond dat wie twijfelt, niet (verschoonbaar) kan dwalen. ${ }^{23}$ Wie in situaties van (bekende) twijfel handelt, neemt alle aan die handeling verbonden risico's ten laste. Dat is nu precies wat zich voordoet in complexe situaties. Wat complex is maar ontrafeld kan worden, laat weinig ruimte voor twijfel, zodat aan de onderneming onzorgvuldigheid wordt verweten als zij de twijfel laat bestaan, zeker als het gaat om een grote onderneming die over een juridische dienst beschikt. De Advocaat-Generaal verwacht een volledige uiteenzetting van de advocaat, zodat de bedrijfsjurist de advocaat op elke denkfout zou moeten kunnen betrappen, op straffe van zelf nalatig te zijn, wat dan weer aan de onderneming wordt toegerekend. Alleen kleine ondernemingen zonder eigen juridische dienst zouden in het systeem van Advocaat-Generaal Kokott nog een rechtsdwaling kunnen inroepen, maar alleen dan wanneer de advocaat te zeker van zijn stuk is geweest en zich, zonder verder voorbehoud, positief over het voorgenomen marktgedrag heeft uitgelaten. Wie evenwel met adviezen van advocaten vertrouwd is, weet te appreciëren wat Rozie van een Nederlandse auteur overnam:

'De belangrijkste beperking van een adviseur is dat hij niet meer duidelijkheid kan scheppen dan het recht hem biedt. En een adviseur zal - al is het maar uit aansprakelijkheidsoverwegingen - al snel benadrukken dat iets juist niet duidelijk is. Met het inwinnen van advies schiet de burger dus lang niet altijd iets op, behalve dat het onzekere karakter van het recht nog eens wordt ingescherpt'. ${ }^{324}$

32I Een aantal annotators stemt omwille van de rechtszekerheid in met de strenge Schenkeruitspraak: L. Idot, 'L'erreur sur l'existence d'une infraction ne fait pas échapper les entreprises à l'infliction d'amendes', Revue des contrats 2013, I388-1392; T. von Danwitz, 'Ignorantia Legis Non Excusat', Journal of European Competation Law \& Practice, 2013, 389-39o. Voor een andere Duitse auteur blijft de vraag naar rechtswaling evenwel open omdat het Hof van Justitie de vraag omtrent de geldigheid van een overheidshandeling in het licht van het vertrouwensbeginsel met de beweerdelijk gans andere (en positief te beantwoorden) vraag naar de mogelijkheid van rechtsdwaling zou hebben verward: C. Kersting, 'Behandlung des unvermeidbaren Verbotsirrtums im europäischen Kartellrecht', Wirtschaft und Wettbewerb 2013, 845-850.

322 Vergelijk de opmerking dat 'degene die speculatief gedrag vertoont' wordt geassimileerd met een persoon die niet te goeder trouw is (N.A. De Vos, 'Het vertrouwensbeginsel in rechtsvergelijkend perspectief met inbegrip van het Europese vertrouwensbeginsel', CDPK 2012, p. 543, nr. I9, voetnoot 70). Of nog, bij onzekere en controversiële rechtspraak heeft de betrokkene 'in feite niet gedwaald, maar wel gegokt want hij weet goed dat de rechtspraak controversieel is' (B. Bouckaert, o.c., 1364 ).

323 Zie bijvoorbeeld R. Kruithof, 'Verbintenissen - Overzicht van rechtspraak (I974-I980)', TPR I983, p. 553, nr. 47 .

324 J. Rozie, o.c., p. 8I5, nr. 32, met verdere verwijzing naar Borgers. 
Het besluit dat de rechtspraak van zowel het Hof van Cassatie als het Hof van Justitie streng is ten opzichte van het als excuus voor een dwaling ingeroepen advies van een advocaat, geldt wanneer de diensten van een andere beroepsbeoefenaar worden ingeschakeld. Zo zal het feit dat de vergissing in de berekening van douanerechten door de ingeschakelde douane-expediteur werd begaan, niet tot ontheffing van aansprakelijkheid leiden:

'De ondernemers zouden immers de voorwaarden in verband met de beroepservaring kunnen omzeilen door systematisch gebruik te maken van de diensten van specialisten op douanegebied en aldus zouden (...) de ondernemers die hun douanehandelingen alleen verrichten, benadeeld zijn vanuit het oogpunt van de procedure van artikel 239 van het douanewetboek. ${ }^{325}$

Evenmin baat het feit dat een aannemer de mening van de bouwheer bevestigt dat het toezicht van een architect op de bouw van een woning niet vereist is. ${ }^{326}$

Telkens is het geheel van de omstandigheden in beeld te brengen en blijft de bottom line of een vergissing omtrent het recht, alle feitelijke omstandigheden in acht genomen, de gevolgen van een onrechtmatigheid niet kan neutraliseren. Sommige factoren kunnen daarbij zwaar doorwegen, zoals de ondernemershoedanigheid van de zich vergissende inbreukpleger in de rechtspraak van het Hof van Justitie inzake mededingingsinbreuken.

\subsubsection{Advies of informatie, uitgaande van de overheid}

I37. Er wordt meer dan eens beweerd dat 'de burger mag vertrouwen op voldoende kennis bij overheidsorganen omtrent de juiste uitleg van eigen wet- en regelgeving van die overheid'. ${ }^{327} \mathrm{Al}$ zit hierin een kern van waarheid, de bewering is veel te ongenuanceerd.

Indien de bevoegde overheid voor een bepaalde handeling het groene licht geeft, dan spreekt het voor zich dat de rechtsonderhorige die toelating als een excuus zal inroepen, mocht achteraf blijken dat de handeling toch onrechtmatig is (althans indien de overheid volledig door de rechtsonderhorige op de hoogte werd gebracht). Door dat excuus kan hij aan de toepassing van de rechtsregel ontsnappen, minstens de foutaansprakelijkheid van de overheid met succes inroepen.

In het geval van een advies of informatie uitgaande van een overheid, is het Hofvan Cassatie merkelijk milder dan ten aanzien van adviezen van een andere rechtsonderhorige. ${ }^{22}$ Zo verwierp het Hof met een arrest van 29 april I998 de cassatievoorziening

325 HvJ 20 november 2008, nr. C-38/07P, Heuschen \& Schrouff, ov. 53.

326 Cass. 20 april I982, RW I983-84, kol. 2919 (vernietigingsarrest).

327 Toerekening wordt veelal gefundeerd door het beoordelen van vrijheid en verantwoordelijkheid, aldus P. Memelink, Ti-ta-toerekening. Over toedoen, onwetendheid en vertrouwen bij de toerekening van gedragingen, in Ex Libris Hans Nieuwenhuis: opstellen aangeboden aan prof. mr. J.H. Nieuwenhuis, Kluwer, 2008, p. 600.

328 Zie het verwerpingsarrest van Cass. 29 april I998, Arr. Cass. I998, p. 480, nr. 2 I9 ('het arrest de rechtvaardigingsgrond aanneemt, op grond dat de verweerders redelijkerwijs in de overtuiging konden verkeren dat zij overeenkomstig de strafwet handelden, overtuiging die gegrond was op de hun door de bevoegde bestuurlijke overheid gegeven adviezen'); zie verdere voorbeelden bij 
tegen een uitspraak waarin een onoverkomelijke dwaling was vastgesteld 'op grond dat de verweerders redelijkerwijs in de overtuiging konden verkeren dat zij overeenkomstig de wet handelden, overtuiging die gegrond was op de hun door de bevoegde bestuurlijke overheid gegeven adviezen'. ${ }^{329}$ Ook de strafrechterlijke rechtsleer blijkt ontvankelijker voor onoverkomelijke dwaling opzichtens adviezen van een bevoegde overheid. De Smet geeft daarvoor de volgende verklaring: 'Een normaal zorgvuldig persoon mag erop vertrouwen dat de bevoegde overheid zelf de draagwijdte van de wet kent, zodat het bij een foutief advies redelijk is dat de betrokkene van alle strafrechtelijke verantwoordelijkheid geëxonereerd wordt. ${ }^{3} 30$

Toch is dit beoordelingselement evenmin absoluut. Indien het overheidsadvies manifest onjuist was en de onjuistheid ervan op zeer eenvoudige wijze was te achterhalen, dan is de daaruitvolgende dwaling niet onoverkomelijk. ${ }^{33^{\mathrm{I}}}$ Een rechtsdwaling wordt evenmin aanvaard wanneer een onderneming op een onjuist of dubbelzinnig interview van een minister voortgaat. ${ }^{332}$

Volgens Glansdorff is het Hof van Cassatie overigens met een arrest van I8 januari 1999 strenger geworden met betrekking tot informatie verstrekt door de overheid. ${ }^{333}$ In dat arrest aanvaardde het Hof, in een situatie waarin de fiscale overheid een verkeerde begindatum voor de termijn voor indiening van een bezwaar had aangegeven, het beroep op de onoverkomelijke dwaling niet om alsnog te horen zeggen dat het bezwaar toch ontvankelijk werd ingediend. ${ }^{334}$ Glansdorff staat perplex bij dit arrest omdat onduidelijk is wat meer van de belastingplichtige kon worden verwacht. 335

De rechtspraak van het Hof van Justitie is milder dan dit laatste arrest. Al mag een belastingplichtige niet zomaar voortgaan op een algemene administratieve bekendmaking die slechts indicatief is, toch kan hij/zij zich wel op het rechtszekerheidsbeginsel beroepen wanneer hij/zij 'zich verlaat op concrete inlichtingen die hij in

M. Faure, o.c., p. 943, nr. I3. Zie ook Bergen 20 oktober 1972, RDS 1973, 24I (dwaling aanvaard in een zaak waarin een werkgever geen minimumloon geldend in collectieve overeenkomsten van bepaald paritair comité had betaald omdat deze voor gelijkaardige feiten voorheen was vrijgesproken en geen administratieve overheid uitdrukkelijk had meegedeeld dat de werkgever niet onder de bevoegdheid van dat paritair comité viel).

329 Cass. 29 april I998, Arr. Cass. I998, p. 480, nr. 2 I9.

330 B. De Smet, o.c., I292.

33I M. Faure, o.c., p. 943 , nr. I3.

332 Corr. Brussel 20 november I992, JLMB I993, I83 (tabaksreclamegeval; 'qu'en règle générale, une telle interview ne traduit que l'avis personnel du ministre sur les questions qui lui sont posées').

333 F. Glansdorff, o.c., p. 737, nr. I6.

334 Cass. I8 januari I999, RCJB 2000, 725, noot F. Glansdorff, 'Erreur invincible ou croyance légitime' (vernietigingsarrest): 'en accep(tant) dans une procédure fiscale, sans plus, comme début du délai prévu à peine de déchéance, la date renseignée par l'administration des contributions, dans une lettre écrite dans le souci de l'avertir de ce délai' na de overweging 'la simple constatation que la victime de l'erreur a été mal informée, même par une personne qualifiée, ne saurait suffire'.

335 F. Glansdorff, o.c., p. 734, nr. I2 en p. 74I, nr. 22. 
een concreet geval desgevraagd van de autoriteiten heeft verkregen'. ${ }^{33^{6}}$ Wanneer op de overheid een informatieplicht weegt, geldt dit des te meer. ${ }^{337}$

In het kader van btw-wetgeving geeft het Hof van Justitie in het Elmeka-arrest aan dat het criterium erin bestaat na te gaan of bij de voorzichtige en bezonnen marktdeelnemer een redelijk vertrouwen door de administratie is gewekt (bijvoorbeeld door aan te geven dat een handeling vrijgesteld is van btw) en, zo ja, of het vertrouwen gewettigd is. ${ }^{33^{8}}$ Het gaf ook aan dat het van belang is na te gaan welke nationale instantie bevoegd is om vragen terzake te behandelen en of de geviseerde handeling van die bevoegde instantie uitgaat.

Volgens de rechtspraak van het Hof van Justitie inzake douanerechten moeten de marktdeelnemers bij twijfel 'inlichtingen inwinnen bij de bevoegde autoriteiten' willen ze zich op rechtsdwaling kunnen beroepen. ${ }^{339}$ Dat wijst erop dat de overheid de laatste stap is die van een burger mag worden verwacht, tenzij hij - op eigen risico - beslist met oogkleppen op door te gaan.

Het argument dat 'van een importeur niet meer kennis kan worden verlangd dan van de douaneambtenaren', werd verworpen omdat 'wanneer dit als beginsel zou worden gesteld, het gevolg daarvan zou zijn dat het praktisch onmogelijk zou worden tot navordering over te gaan, omdat een vergissing noodzakelijkerwijze altijd is begaan door een bevoegd ambtenaar die een bepaalde feitelijke of juridische situatie niet vanuit alle gezichtshoeken heeft bekeken'. ${ }^{340}$

Als een advies uitgaande van de overheid als excuus wordt aanvaard, ${ }^{341}$ dan rijst daarbij de (preliminaire) vraag of de administratie al dan niet verplicht is te antwoorden op een vraag om inlichtingen te bekomen. Uit het zorgvuldigheidsbeginsel kan

336 HvJ 28 juni r99o, nr. C-8o/89, Behn, ov. 24. Zie ook in het kader van mededingingsinbreuken, J. Kokott, conclusie van 28 februari 2013 in de zaak C-68I/II, Schenker, nrs. 85-92.

337 Zie voor een voorbeeld in het Belgische recht, Arbh. Bergen I3 juni 1975, JTT I976, 7, noot V.P. (pensioendienst): ‘que pour écarter, à leur profit, l'application d'une loi de droit public, les particuliers ne peuvent invoquer leur ignorance de celle-ci ... mais ... la doctrine et la jurisprudence admettent le tempérament de l'erreur invincible "de droit", 'que nonobstant le silence de la loi, les administrations chargées de la gestion d'un service public, sont tenues de renseigner de manière exacte et complète les particuliers sur les obligations qui leur incombent et de corriger leur ignorance éventuelle de celles-ci'.

$338 \mathrm{HvJ}$ I4 september 2006, nr. C-I8I/04, C-I83/04, Elmeka, ov. 35.

339 Gerecht 30 november 2006, nr. T-382/04, Heuschen \& Schrouff, ov. 79.

340 Gerecht 5 juni I996, nr. 6-75/95, Günzler Aluminium/Commissie, ov. 47. Zie ook HvJ 26 juni I990, nr. C-64/89, Deutsche Fernsprecher, ov. I7. Zie ook HvJ 20 november 2008, nr. C-38/07P, Heuschen \& Schrouff, ov. 64: de loutere aanvaarding van een indeling van goederen door de administratie volstaat niet: 'Het toelaten van een dergelijke nalatigheid zou er immers op neerkomen dat de marktdeelnemers worden gestimuleerd om profijt te trekken van de vergissingen van hun douaneautoriteiten' en ov. 65: 'leidt bovendien de vergissing van de douaneadministratie (...) er niet toe dat de ondernemer in beginsel niet hoeft in te staan voor de gevolgen van zijn eigen nalatigheid'.

34I Voor een lijst van minimumeisen voor het vertrouwen in een beslissing van een nationale mededingingsautoriteit, zie J. Kokott, conclusie van 28 februari 2013 in de zaak C-68I/II, Schenker, nrs. 87 e.v.: (I) de beslissing moet uitgaan van een autoriteit die bevoegd is tot toepassing van het mededingingsrecht, (2) alle relevante feiten moeten vooraf volledig en naar waarheid aan die autoriteit zijn bezorgd, (3) de feiten en juridische kwesties waaromtrent dwaling wordt ingeroepen, moeten juist het voorwerp van de beslissing zijn, (4) de beslissing mag niet kennelijk onjuist zijn en (5) de onderneming moet te goeder trouw zijn. 
mogelijk een informatieplicht lastens de overheid worden afgeleid. ${ }^{342}$ Toch is het een nijpende vraag of een rechtsonderhorige in de plaats van een advies van een beroepsbeoefenaar, de informatie van de overheid kan vragen. Tot een algemene antwoordplicht van de overheid lijkt niet te besluiten.

\section{DEEL 3: De tering naar de nering gezet: besluit}

I38. Het overzicht van rechtspraak en rechtsleer bevestigt dat onwetendheid nopens de toepasselijkheid, dan wel de draagwijdte van een rechtsregel, ongeacht de complexiteit van het rechtsgebeuren, een bijkomende kwalificatie vergt om in rechte relevant te zijn.

Om de, aan onwetendheid toe te rekenen miskenning van een (toepasselijke) rechtsregel met de mantel der liefde te bedekken, worden grosso modo drie patronen gevolgd.

Die onwetendheid moet als een verschoonbare dan wel onoverkomelijke rechtsdwaling zijn te kwalificeren, tot een rechtmatig vertrouwen zijn terug te brengen of, bij sanctie, de rechtszekerheid in het gedrang brengen. ${ }^{343}$

I39. De, hoe dan ook, vereiste bijkomende kwalificatie waaraan de onwetendheid moet voldoen om het 'uilskuiken' in bescherming te kunnen nemen, bevestigt dat de juridische kennis die elkeen zogenaamd geacht wordt te hebben, er niet toe doet. De ontsnappingsroutes bouwen niet op dat gezegde voort, maar op welbepaalde, feitelijke omstandigheden, die het besluit van het bestaan van de vereiste, gekwalificeerde onwetendheid onderbouwen. Het adagium blijkt, met andere woorden, geen toegevoegde waarde te hebben.

Vermits de gekwalificeerde onwetendheid het falende rechtssubject toelaat zich - onder omstandigheden - aan de rechtsgevolgen van een rechtsregelmiskenning te onttrekken, kan inderdaad worden vastgesteld dat zij bescherming biedt tegen de (al dan niet toenemende) complexiteit van het rechtsgebeuren. Vanuit een ander perspectief bekeken lijkt het erop dat de gekwalificeerde onwetendheid - onder omstandigheden - in het privaatrecht (al te veel?) wordt beloond..$^{344}$

342 Zie P. Popelier, thesis, p. 27I, nr. 36r ('Op het bestuur rust een informatieplicht, die mede ertoe dient de rechtzoekende in te lichten over de precieze betekenis en toepassing van wetten en reglementen', met verdere verwijzing). De vraag werd al gesteld door J. Stassen, noot onder Cass. 4 januari 1973, RCJB I974, 346 ('L'intervention de l'Etat dans de multiples domaines de l'activité humaine, la complexité des textes légaux et réglementaires, leur nombre toujours croissant, font que l'administration d'un Etat moderne ne peut se désintéresser de la situation difficile dans laquelle trop souvent l'administré est placé. Certes, "nul n'est censé ignorer la loi", mais qui pourrait soutenir que sur le plan des réalités pratiques cet adage correspond aujourd'hui à une vérité. Il y a dès lors pour l'administration un devoir d'aider l'administré et au besoin de l'informer, de le renseigner, de l'éclairer.').

343 Zie hiervoor nrs. I2O-I29.

344 Zie in die zin P. Memlink, 'Ti-ta-toerekening over toedoen, onwetendheid en vertrouwen bij de toerekening van gedragingen', in Ex libris Hans Nieuwenhuis: opstellen aangeboden aan Prof. Mr. J.H. Nieuwenhuis, Kluwer, 2008, 583-60o (met citaat van Nieuwenhuis). 
Aldus wordt een - vrij wankel - evenwicht gevonden tussen het beginsel dat de rechtsregel (hoe complex het rechtsgebeuren ook is) hoort te worden toegepast van zodra zijn toepassingsvoorwaarden verenigd raken (collectief belang) en uitzonderingen daarop, die het eigenbelang van het in gebreke blijvende rechtssubject op dat collectief belang laten voorgaan.

Indien het tot een algemene theorie omtrent de impact van de (toenemende) complexiteit van het rechtsgebeuren op het rechtssubject moet komen, zullen de aan het eigenbelang onderliggende waarden moeten worden toegelicht.

I40. Dwaling, zijnde een onuitgelokte vergissing, die een verkeerde voorstelling van de werkelijke toedracht tot gevolg heeft, leidt tot onwetendheid nopens die werkelijke toedracht.

Voortgaande op de dwaling handelt ${ }^{345}$ het 'uilskuiken', tot de vergissing wordt ingezien en er brokken zijn te lijmen.

Zowel bij de verschoonbare rechtsdwaling (wilsgebrek), als bij de onoverkomelijke rechtsdwaling (rechtvaardigingsgrond) ligt de nadruk op de onwetendheid van de falende persoon. Er wordt aangenomen dat hij/zij, ten gevolge van zijn/haar vergissing, niet uit vrije wil heeft kunnen handelen, zodat de gevolgen van de op die vergissing berustende handelingen niet toerekenbaar zijn.

Hoewel de terminologie verschilt, wordt slechts tot verschoonbaarheid dan wel onoverkomelijkheid van de rechtsdwaling besloten, wanneer de onwetendheid en de vergissing aan omstandigheden zijn toe te rekenen die, cumulatief, vreemd zijn aan de wil van de betrokkene en bovendien voor hem/haar onvoorspelbaar en onoverkomelijk zijn.

De lat ligt (zeer) hoog: de miskenning van de rechtsregel als gevolg van een vergissing moet aan een vreemde oorzaak ${ }^{346}$ zijn toe te rekenen.

Wie twijfelt, doch nalaat om die twijfel door bijkomend onderzoek weg te nemen, heeft de vergissing/onwetendheid met betrekking tot de (in werkelijkheid) toepasselijke rechtsregel te danken aan zijn/haar (wils)beslissing om de onduidelijkheid niet uit te klaren.

De onoverkomelijkheid en/of onvoorspelbaarheid wordt beoordeeld in functie van de concrete feitelijke omstandigheden, waarin een normaal voorzichtig en redelijk persoon (beroepsbeoefenaar) wordt geprojecteerd.

$\mathrm{Al}$ die voorzorgen om aan onwetendheid een rechtsgevolg te hechten, drukken de (collectieve) bekommernis uit te vermijden dat de rechtsgevolgen van een (vastgestelde) rechtsregelmiskenning al te gemakkelijk van de persoon worden afgewenteld die de vergissing beging.

Hij/zij ontsnapt aan de sanctie/dwang waarmee rechtsregelmiskenning gepaard gaat, wanneer hij/zij noch subjectief (geen wilstekort), noch objectief (volgens de algemene zorgvuldigheidsnorm) in gebreke is gebleven. Alleen dan is de door

345 De handeling kan de vorm van een rechtshandeling dan wel van een rechtsfeit aannemen.

346 Om tot een vreemde oorzaak te besluiten, moet de ingeroepen omstandigheid immers vreemd zijn aan de wil van de persoon die zich erop beroept, alsmede onoverkomelijk en onvoorspelbaar zijn (zie onder meer P. Van Ommeslaghe, o.c., II, I38I-I402; P. Wéry, o.c., I, 538-553). 
onwetendheid/vergissing te verklaren rechtsregelmiskenning niet aan de betrokkene toerekenbaar.

Het zijn jurisprudentiële rechtsregels, gebaseerd op wetsbepalingen, die zulks voor elkaar hebben gekregen.

De (algemene, abstracte en duurzame) criteria die daartoe door de rechtspraak werden ontwikkeld, laten de beoordelers nog steeds een aanzienlijke marge, toelatend om met alle concrete omstandigheden rekening te houden. De hiervoor besproken complexiteit van de rechtsbedeling staat daarvoor borg.

I4I. Wat voegt het rechtmatig vertrouwen aan het voorgaande toe?

Het vertrouwen waarop wordt gezinspeeld, verwijst naar de mening dat een rechtsregel (al dan niet) toepasselijk is, dan wel (al dan niet) een welbepaalde inhoud heeft. Daarop gaat de betrokkene in vertrouwen voort. Naderhand blijkt dat die mening feitelijke grondslag miste: een rechtsregel werd daardoor, bij veronderstelling, miskend.

De betrokkene wil evenwel niet op de blaren gaan zitten: hij/zij voert aan dat de persoon aan wie zijn/haar - onterechte - vertrouwen toerekenbaar is, op zijn/haar beurt de vergissing voor lief moet nemen, zodat tussen die partijen zou zijn af te rekenen alsof er zich geen vergissing voordeed.

Om dit kunstzinnige, want virtuele resultaat te bereiken, moet het vastgestelde vertrouwen, berustend op vergissing, een rechtmatig karakter hebben..$^{347}$

Wanneer het vertrouwen op een rechtsdwaling berust die zich in een rechtsverhouding tussen private rechtssubjecten voordoet, rijst vanzelfsprekend de vraag of met de vertrouwensleer andere resultaten dan inzake verschoonbare, respectievelijk onoverkomelijke rechtsdwaling zijn te behalen.

Weliswaar gaat het bij een rechtsdwaling over een onuitgelokte verkeerde voorstelling van de feiten, terwijl in het kader van de vertrouwensleer wordt benadrukt dat het vertrouwen, op enige wijze, aan de verweerder moet zijn toe te rekenen.

Laatstgenoemde precisering strekt er echter niet toe om de vinger op een tekortkoming van de verweerder te leggen, maar wel om tot een feitelijk verband en, daaruitvolgend, een door de vertrouwensleer beheerste rechtsverhouding te kunnen besluiten. Veel verschil maakt dit niet uit.

De verslaggevers neigen er derhalve toe aan te nemen dat slechts tot rechtmatigheid van het ingeroepen vertrouwen, in private rechtsverhoudingen, is te besluiten in omstandigheden die wijzen op een hetzij verschoonbare, hetzij onoverkomelijke rechtsdwaling.

347 Met betrekking tot de vertrouwensleer in het algemeen zie onder meer S. Stijns en I. Samoy, 'La confiance légitime en droit des obligations', in S. Stijns en P. Wéry (eds.), Les sources d'obligations extracontractuelles, Brugge, die Keure, 2007, 47 e.v. 
Indien de rechtmatigheid een ruimere aflijning zou vergen, moeten de promotoren van de vertrouwensleer precies weten aan te tonen welke feitelijke omstandigheden ertoe moeten leiden aan vertrouwen, gesteund op een vergissing/onwetendheid, meer bescherming dan aan een verschoonbare of onoverkomelijke rechtsdwaling te laten toekomen, willen ze niet met het gelijkheidsbeginsel in de knoop geraken. De onduidelijkheid die de vertrouwensleer blijkt te kenmerken, ${ }^{348}$ stemt niet hoopvol.

In rechtsverhoudingen met de overheid blijkt de vertrouwensleer volledig in het zogenoemd rechtszekerheidsbeginsel op te gaan; ${ }^{349}$ ze worden hierna samen behandeld.

I42. Het rechtzekerheidsbeginsel, dat met het legaliteitsbeginsel sensu lato zou overeenkomen, blijkt te peilen naar de duidelijkheid van wetsbepalingen dan wel van jurisprudentiële rechtsregels.

Het steekt de kop op in rechtsverhoudingen met de overheid, wanneer deze de toepassing van een rechtsregel vordert, die door een rechtssubject ${ }^{350}$ niet is nageleefd, omdat het door de ingeroepen onduidelijkheid of door de abrupte wijziging van de rechtsregel op het verkeerde been is gezet.

De 'rule of law'35I snelt het rechtssubject ter hulp dat een rechtsregel niet of verkeerd heeft begrepen, omdat daarin van onduidelijke bewoordingen gebruik is gemaakt, dan wel omdat de rechtsregel abrupt werd gewijzigd en het, als gevolg daarvan, in strijd daarmee heeft gehandeld.

Aan de overheid wordt, wegens die tekortkoming, opgelegd om van sanctie/dwang af te zien: het collectief belang wordt niet ter harte genomen omdat de wetgever/de rechtspraak bij de formulering van de rechtsregel in gebreke bleef: het eigenbelang van de rechtsregelovertreder krijgt daarom de voorrang. ${ }^{352}$ Aan de regelgever wordt de wacht aangezegd.

348 Zie hiervoor nr. I23.

349 Zie hiervoor nr. I25.

350 Dat overigens een andere overheid kan zijn, want de overheid heeft (zeer) vele verschijningsvormen.

35I Zie EHRM 7 juli 20II, Serkov/Ukraine, ov. 33: 'the rule of law, one of the fundamental principles of a democratic society, is inherent in all the Articles of the Convention'. Zie ook J. Rozie, o.c., p. 817, nr. 35 omtrent lex certa: 'Er mag niet worden geraakt aan de beschermde waarde van het legaliteitsprincipe daar het de kern is van de rechtsstaat of "the rule of law"'; B. Van den Bergh, o.c., p. 364 , nr. 37 over het rechtszekerheidsbeginsel: 'Het gaat om een grondwettelijk algemeen beginsel, inherent aan de " rule of law", waaraan alle rechtsinstrumenten (niet enkel de wet, maar ook de rechtspraak) getoetst - zouden moeten - kunnen worden. Het betreft bijgevolg een eigenschap die afdwingbaar is (of zou moeten zijn) van elke staatsmacht.'

352 B. Bouckaert, o.c., p. I395, nr. I8; B. Van den Bergh, o.c., p. 358, nr. 29. In een vonnis van 26 januari 2007 wees de Rechtbank van Eerste Aanleg te Leuven de redenering van de overheid af dat een roerende voorheffing moest worden ingehouden voortbouwend op de idee dat de wetgever de bedoeling niet naar behoren in de wet had omgezet (Rb. Leuven 26 januari 2007, TRV 2013, (I98) 20, nr. I2, inzake verkrijgingsboni bij een inkoop van eigen aandelen). 
Op het eerste zicht is nochtans tot rechtszekerheid te besluiten wanneer de rechtssubjecten weten dat rechtsregels op hen toepasselijk zijn van zodra de toepassingsvoorwaarden ervan verenigd raken. Daarop uitzonderingen voorzien schept onzekerheid, tenzij die uitzonderingen scherp zijn omlijnd.

Er is geen sprake van scherpe omlijning wanneer de afdwingbaarheid van de rechtsregel betwistbaar wordt omwille van 'onduidelijke formulering' of van 'abrupte wijziging'.

Wanneer is een formulering al dan niet onduidelijk of is een wijziging abrupt?

Eenieder zal daarover wel een mening hebben, maar in afwezigheid van een algemeen, abstract en duurzaam criterium zal het de ultieme feitenbeoordeler zijn die daarover beslist en wiens persoon aldus het ultieme criterium van de toepasselijkheid van de rechtsregel wordt.

Het kan dan ook niet verbazen dat de gevallen waarin een rechtsregel op grond van het zogenoemde rechtszekerheids- of legaliteitsbeginsel buitenspel werd verklaard, er magertjes bij lopen.

De coherentie zou overigens zoek zijn, wanneer een rechtsregel ten aanzien van één welbepaald rechtssubject buiten toepassing wordt gelaten omdat de overheid zich aan een tekortkoming, in de vorm van een 'onduidelijke' formulering of van een 'abrupte' wijziging, schuldig zou hebben gemaakt.

Moet het collectief belang, dat door de rechtsregel wordt gediend, daarvoor boeten?

Hoe zou dit overigens te rijmen zijn met het feit dat de zogenaamd onduidelijk geformuleerde of abrupt gewijzigde rechtsregel blijft voortbestaan en dus ten aanzien van andere rechtssubjecten verder wordt toegepast?

I43. 'The rule of law' drukt de fundamentele gedachte uit dat de samenleving op basis van (algemene, abstracte, duurzame) rechtsregels is te structureren, te organiseren, te handhaven en te financieren. Zij kunnen zowel van wetgevende, als van jurisprudentiële aard zijn. De jurisprudentiële rechtsregels, op wettelijke rechtsregels gebaseerd, bepalen daarvan de inhoud, de zin en de draagwijdte.

Wettelijke rechtsregels en de daarop voortbouwende jurisprudentiële rechtsregels behoeven, zoals de feiten en hun kwalificatie, steeds interpretatie. De rechtsbedeling is één lang interpretatief proces: de geïnterpreteerde rechtsregels worden via de geïnterpreteerde bewijsmiddelen op geïnterpreteerde feiten toegepast.

Een rechtsregel kan dus niet onduidelijk worden genoemd omdat - zelfs vergaande - interpretatie vereist is. 353

353 De abrupte wijziging, die enigszins met een retroactieve wijziging vergelijkbaar is, is van een andere orde. Daardoor rijst de vraag wat de impact op bestaande rechtsverhoudingen zal zijn. Kennis of kenbaarheid van de toepasselijke rechtsregels doet er dan niet toe. 
De bekommernis in dit kader is niet de vergissing/onwetendheid van een rechtssubject, maar wel de kenbaarheid, meetbaar aan de hand van objectieve criteria, van de inhoud, de zin en de draagwijdte van de rechtsregel.

Indien de formulering van de wettelijke rechtsregel niet toelaat de inhoud, de zin en de draagwijdte ervan te achterhalen, kan er evenmin een welbepaald gebod of verbod worden uit afgeleid. Als er daartoe evenmin jurisprudentiële rechtsregels voorhanden zijn, kan aan het rechtssubject evenmin kwalijk worden genomen ze niet in aanmerking te hebben genomen. Het criterium van de normaal voorzichtige en redelijke mens (beroepsbeoefenaar), in dezelfde omstandigheden geplaatst, biedt alsdan evenmin soelaas om de aldus miskenning van die (immers onbestaande) jurisprudentiële rechtsregels aan het rechtssubject toe te rekenen.

In die context is het overbodig van een zogenoemde beschermde onwetendheid/vergissing te gewagen; het volstaat erop te wijzen dat de ingeroepen rechtsregel niets oplegt dan wel verbiedt. Als aan de regelgever gerichte boodschap uitgaande van de beoordeler, kan dat tellen.

I44. Gezocht: redders in nood. Wie handelt zonder zich af te vragen welke de toepasselijke rechtsregels zijn en tot wat zij strekken of opduikende twijfel dan wel vragen daaromtrent in het midden laat, handelt op eigen risico. Onder omstandigheden zal die houding uitsluiten dat een beroep op de verschoonbare of onoverkomelijke rechtsdwaling is te doen.

Ondanks de begane vergissing, zal de rechtsregel worden toegepast: dura lex, sed lex.

Dat klinkt ogenschijnlijk hard, maar de hiervoor toegelichte complexiteit van het rechtsgebeuren en in het bijzonder van de rechtsbedeling, staan er garant voor dat de beoordeler met alle concrete omstandigheden, in eer en geweten, rekening kan houden.

Een samenleving zonder structuur, organisatie, handhaving en financiering zingt het niet lang uit: de leden ervan horen zulks te weten en te letten op de rechtsregels die het (complexe) geheel verbinden en gestalte geven.

In zekere zin kan van een informatie-inwinningsverplichting worden gesproken, waarvan de inhoud, de zin en de draagwijdte in functie van de zich voordoende feitelijke omstandigheden is te bepalen.

Van het toerekeningsvatbare rechtssubject wordt verwacht dat het informatie over de toepasselijke rechtsregels inwint. Die informatie kan op eigen initiatief worden verzameld: opzoekingen (wetboeken, sociale netwerken), raad van familieleden of vrienden. In precontractuele of contractuele rechtsverhoudingen kan de desbetreffende informatie, onder omstandigheden, ook door de medecontractant zijn te verstrekken.

De informatie bekomen over de toepasselijke rechtsregels, moet vervolgens worden verwerkt/geïnterpreteerd. Zulks blijft ieders verantwoordelijkheid. Op dat precieze 
punt situeert zich de vraag of de - vastgestelde - rechtsregelmiskenning aan een verschoonbare, dan wel onoverkomelijke dwaling is toe te rekenen.

Zij wordt door de beoordeling van de zich voordoende feitelijke omstandigheden gestuurd: van belang zullen onder meer zijn de al dan niet professionele hoedanigheid van de persoon die de rechtsregel heeft miskend en de omvang van de onderneming, die tot verstrenging van de gedragsnorm leidt. ${ }^{354}$ De complexiteit van het rechtsgebeuren kan als een feitelijke omstandigheid bij de beoordeling worden betrokken. ${ }^{355}$ Die feitenbeoordeler staat aan het stuur en dat verantwoordt de nadruk die op verenigbaarheid van zijn beslissing met de onderliggende rechtsregels wordt gelegd. ${ }^{356}$

Onder dat belangrijke voorbehoud, wordt aldus tegemoet gekomen aan de bekommernis van Schuck, ${ }^{357}$ namelijk dat de complexiteit van het rechtsgebeuren een hoge kostprijs dreigt te hebben voor de personen die juridisch niet of weinig onderlegd zijn, wat gelet op de financiële ongelijkheden voor niet of minder begoeden onoverkomelijk wordt.

I45. Gevonden: redders in nood. Rechtssubjecten die over de daartoe vereiste financiële middelen beschikken, zullen het zekere boven het onzekere verkiezen en een beroep doen op (bezoldigde) raadgevers om te vernemen welke rechtsregels, met welke draagwijdte, toepasselijk zijn. Die analyse is overigens vaak de start van de, hierboven ${ }^{35^{8}}$ kritisch benaderde, rechtsregelontwijking.

Errare humane est: ook (bezoldigde) raadgevers kunnen zich - om sterk uiteenlopende redenen zoals gebrek aan inzicht, aan ervaring, aan onafhankelijkheid, aan tijd, aan inzet, enz. - vergissen.

De vraag wordt dan of de vergissing van de raadgever door zijn opdrachtgever als een verschoonbare, dan wel onoverkomelijke rechtsdwaling is in te roepen.

De toestand buiten beschouwing latend waarin de (bezoldigde) raadgever een uitvoeringsagent van de opdrachtgever is, die in zijn plaats een contractuele verbintenis nakomt, ${ }^{359}$ komt de tussenkomst van de (bezoldigde) raadgever niet als dusdanig

354 In die zin Corr. Veurne 3 juni I983, RW I983-84, 2780 met noot P. Arnou; P. Van Den Bon, noot onder Antwerpen 9 oktober 1997, Soc. Kron. I998, I45.

355 Zie bijvoorbeeld Arbrb. Hasselt 9 mei, JT r995, 2 Io.

356 Zie hiervoor nrs. 32-4I.

357 Een van de weinigen die op de complexiteit van het recht inging (P.H. Schuck, 'Legal complexity some causes, consequences and cures', Duke Law Journal 42(I), I992, I9 en 23): '(complexity) is not neutral in its effects; it advantages some groups and disadvantages others'. Dit heeft tot gevolg dat niet alle burgers op dezelfde wijze tegen het complexe rechtsgebeuren (kunnen) aankijken en ermee (kunnen) omgaan.

358 Zie hiervoor nrs. IIO-III.

359 Rechtspraak en rechtsleer nemen overwegend aan dat de tekortkoming van de uitvoeringsagent aan de opdrachtgever toerekenbaar is, ongeacht de aard van de contractuele verbintenis die is na te komen; zie onder meer S. Stijns, 'Samenloop van civielrechterlijke aansprakelijkheidsregimes: quo vadis?', in H. Vuye en Y. Lemense, Springlevend aansprakelijkheidsrecht, Antwerpen, Intersentia, 20II, I67-I68. 
als een rechtvaardigings- of verschoningsgrond ten aanzien van de daaropvolgende rechtsregelmiskenning in aanmerking.

Daartoe is bijkomend vereist dat het ontvangen advies de opdrachtgever in een toestand van verschoonbare, dan wel onoverkomelijke dwaling brengt.

Uit het mededingingsrecht, en in het bijzonder de hiervoor toegelichte conclusie van Advocaat- Generaal Kokott, ${ }^{60}$ blijkt dat de beoordeling ervan in ondernemingsverband en zulks ter vrijwaring van de zogenoemd vrije mededinging, op grond van zeer strenge parameters gebeurt.

In andere sectoren, met betrekking tot andere activiteiten die op andere waarden steunen, kan die beoordeling een ander gelaat vertonen.

Wanneer de rechtsregelmiskenning het gevolg is van een verkeerd advies, dat door de opdrachtgever niet als een verschoonbare, dan wel onoverkomelijke rechtsdwaling is in te roepen, kan laatstgenoemde de (fout)aansprakelijkheid van de raadgever in het vizier nemen, de last die de rechtsregelmiskenning voor hem tot gevolg heeft, in te vergoeden schade omzettend.

De opdrachtgever moet daartoe wel het hindernissenparcours van het aansprakelijkheidsrecht op. ${ }^{36 \mathrm{r}}$

I46. De overheid die met (veel) minder (veel) meer moet zien te doen. Vermits de rechtsregels van bevoegde overheden uitgaan, rijst vervolgens de vraag of het niet tot de taak van de overheid behoort om over de toepasselijkheid van de rechtsregels, ex ante, klare wijn te schenken. Kan aldus van de overheid worden verwacht dat zij, op bevraging, de toepasselijkheid van de rechtsregels bepaalt en daardoor de verantwoordelijkheid van de vraagsteller overneemt?

Ten aanzien van de wetgevende en de rechterlijke machten lijkt daarvoor, alleszins, geen ruimte te bestaan.

Noch de wetgevende, noch de rechterlijke machten staan in voor de uitvoering van wetten, zoals die gebeurlijk door jurisprudentiële rechtsregels werden uitgewerkt. Die taak komt aan de uitvoerende machten toe.

Vermits de uitvoering van de wetten wordt bevorderd wanneer de rechtssubjecten de voorzorg nemen om bij uitvoerende overheden over de toepasselijkheid van de rechtsregels inlichtingen in te winnen, lijkt er veel voor te zeggen om die overheid daarbij te betrekken.

Voorzichtigheid is evenwel op haar plaats en niet alleen om de overheid voor aansprakelijkheid te behoeden..$^{362}$

Het zijn immers de vraagstellers die, in de regel, verantwoordelijk zijn en moeten blijven voor het feitenrelaas dat zij aan de overheid voorleggen, die, op grond daarvan, zou bepalen welke rechtsregels toepasselijk zijn.

360 Zie hiervoor nr. 136.

36I Door H. De Page reeds met de hellespreuk bedacht Lasciate ogni speranza, voi ch'entrate (zie Traité élémentaire de droit civil, II, Brussel, Bruylant, I964, 857).

362 Zie hiervoor nrs. II4-II5. 
Er kan van de overheid mogelijk worden verwacht dat zij op inconsistenties in dat verhaal wijst, maar niet dat zij onderzoekt of de voorgelegde feiten door de vraagsteller volledig, dan wel juist worden weergegeven.

Ongeacht of de overheidstussenkomst op een bijzondere wettekst dan wel op een op de overheid toepasselijk algemene zorgvuldigheidsnorm is gestoeld en ongeacht of het de vorm van een advies, een raad of een 'ruling' betreft, in alle gevallen is de draagwijdte ervan strikt te beperken tot de aan de overheid voorgelegde feitelijke informatie.

De binnen dat strikte feitelijke kader te situeren overheidstussenkomst zal, wanneer blijkt dat de verstrekte informatie de rechtsregelmiskenning niet heeft vermeden, mogelijk bij de betrokkene tot een toestand leiden die, onder omstandigheden, als een verschoonbare, dan wel onoverkomelijke dwaling is te kwalificeren. Van automatisme kan evenwel geen sprake zijn, vermits de beoordeler over een aanzienlijke, feitelijke (beoordelings)marge blijft beschikken. Indien tot geen verschoonbare dan wel onoverkomelijke dwaling wordt besloten, kan de betrokkene die de rekening krijgt voorgeschoteld, zijn/haar gram op de overheid verhalen, mits het bewijs van de aansprakelijkheidsvoorwaarden te leveren.

Daarbij is te benadrukken dat op de (uitvoerende) overheid soms de wettelijke verplichting wordt gelegd om rechtssubjecten informatie over hun rechtstoestand te verstrekken. ${ }^{363}$

Afgezien daarvan, rust op de overheid geen algemene informatieverstrekkingsplicht.

Wel zal, bij betwisting, in functie van de concrete omstandigheden zoals ze zich voordeden, zijn te bepalen of, al dan niet, een algemene zorgvuldigheidsnorm bestond om welbepaalde informatie (al dan niet op bevraging) aan een rechtssubject met betrekking tot de toepasselijke rechtsregels en/of hun draagwijdte te verstrekken. Indien de overheid naliet die algemene zorgvuldigheidsnorm (correct) na te komen, zal dit bij de beoordeling van de (overheids)aansprakelijkheid van belang zijn.

363 Zoals onder meer artikel 3 van de Wet van II april 1995 tot invoering van het handvest van de sociaal verzekerde. 